\title{
Mobility and fluxes of trace elements and nutrients at the sediment- water interface of a lagoon under contrasting water column oxygenation conditions
}

\author{
Sylvain Rigaud ${ }^{\mathrm{a}, 1, *}$, Olivier Radakovitch ${ }^{\mathrm{a}}$, Raoul-Marie Couture $^{\mathrm{b}}$, Bruno Deflandre ${ }^{\mathrm{c}}$, Daniel Cossa ${ }^{\mathrm{d}}$, \\ Cédric Garnier ${ }^{\mathrm{e}}$, Jean-Marie Garnier ${ }^{\mathrm{a}}$
}

\footnotetext{
a CEREGE, CNRS, Aix-Marseille University, IRD, Collège de France, Europôle Méditerranéen de l'Arbois, BP 80, 13545 Aix-en-Provence Cedex 4, France

${ }^{b}$ Department of Earth and Environmental Sciences, 200 University Avenue West Waterloo, Ontario N2L 3G1, Canada

c University Bordeaux I, Environnements et Paléoenvironnements Océaniques et Continentaux (EPOC), UMR 5805, CNRS, Avenue des Facultés, 33405 Talence, France

d IFREMER, Centre de Méditerranée, BP 330, Zone Portuaire de Brégaillon, 83507 La Seyne-sur-Mer, France

e PROTEE, Sud Toulon-Var University, BP 20132, 83957 La Garde Cedex, France

${ }^{1}$ Current address: University Bordeaux I, Environnements et Paléoenvironnements Océaniques et Continentaux (EPOC), UMR 5805, CNRS, Avenue des Facultés, 33405 Talence, France.
}

*: Corresponding author : Sylvain Rigaud, tel.: +33 540002996 ; fax: +33 556840848 ;

email address : rigaud sylvain@hotmail.fr

\begin{abstract}
:
The early diagenesis of the major carrier phases (Fe and Mn minerals), trace elements (As, Co, Cr, $\mathrm{Hg}, \mathrm{MeHg}, \mathrm{Ni})$ and nutrients $\left(\Sigma \mathrm{NO}_{3}, \mathrm{NH}_{4}{ }^{+}, \Sigma \mathrm{PO}_{4}\right)$ and their exchange at the sediment water/interface were studied in the Berre Lagoon, a Mediterranean lagoon in France, at one site under two contrasting oxygenation conditions (strictly anoxic and slightly oxic) and at an adjacent site with perennially welloxygenated water. From the concentration profiles of the primary biogeochemical constituents and trace elements of the pore and bottom waters, as well as the total and reactive particulate phases, we were able to locate and identify the diagenetic reactions controlling the mobility of trace elements in the sediments and quantify their rates by coupling one-dimensional steady-state transport-reaction modelling and thermodynamic speciation calculations.

Under oxic conditions and in the absence of benthic organisms, the main redox reactions were well identified vertically in the surface sediments and followed the theoretical sequence of oxidant consumption: $\mathrm{O}_{2}>\Sigma \mathrm{NO}_{3} / \mathrm{MnO}_{2}>\mathrm{Fe}(\mathrm{OH})_{3}>\mathrm{SO}_{4}{ }^{2-}$. However, under anoxic conditions, only $\mathrm{MnO}_{2}$, $\mathrm{Fe}(\mathrm{OH})_{3}$ and $\mathrm{SO}_{4}{ }^{2-}$ reduction were present, and they all occurred at the interface. We identified the main biogeochemical controls on the mobility of $\mathrm{As}, \mathrm{Cr}, \mathrm{Hg}, \mathrm{MeHg}$ and $\mathrm{Ni}$ in the surface sediments as the adsorption/desorption and/or coprecipitation/codissolution with Fe oxy-hydroxides. In contrast, Co mobility was primarily controlled by its reactivity towards Mn oxy-hydroxides. In sulphidic sediments, As, $\mathrm{Hg}$ and $\mathrm{MeHg}$ were sequestered along with Fe sulphides, whereas Co and Ni precipitated directly as metallic sulphides and $\mathrm{Cr}$ mobility was enhanced by complexation with dissolved organic ligands.

The fluxes of trace elements at the sediment-water interface are essentially dependent on the localisation of their remobilisation and immobilisation reactions under the interface, which in turn is
\end{abstract}


governed by the benthic water oxygenation conditions and kinetic competition among those reaction and diffusion processes. Under oxic conditions, the precipitation of $\mathrm{Fe}$ or $\mathrm{Mn}$ oxy-hydroxides in the surface sediments constitutes the most efficient mechanism to sequester most of the trace elements studied, thus preventing their diffusion to the water column. Under anoxic conditions the export of trace elements to the water column is dependent on the kinetic competition among the remobilisation during the reductive dissolution of $\mathrm{Fe}$ and/or $\mathrm{Mn}$ oxy-hydroxides, diffusion and immobilisation with sulphides. We also show that benthic organisms in the perennially oxygenated site have a clear impact on this general pattern. Based on our extensive dataset and geochemical modelling, we predict that the planned reoxygenation of the entire lagoon basin, if complete, will most likely limit or reduce the export of the trace elements from the sediments to the water column and therefore limit the impact of the contaminated sediment.

\section{Highlights}

Main constituents and trace elements concentration profiles in contaminated sediments. Contrasting oxygen concentrations in the overlying water column. Combination of thermodynamic calculations and inverse transport-reactions modelling. Identification and quantification of diagenetic reactions controlling trace elements mobility. Assessment of trace elements and nutrients fluxes at the sediment-water interface.

\section{Introduction}

During the last century, most coastal areas were strongly impacted by the development of anthropogenic activities on their shores and the subsequent inputs of contaminants or nutrients. Although these releases were significantly reduced during recent decades because of regulations, contaminants accumulated in the sediment over time. These sediments now constitute a potential source of contaminants for the water column that could alter the water quality and threaten aquatic organisms. Understanding the processes controlling the dynamics of contaminants in the sediment, improving our knowledge of the environmental risk induced by contaminated sediments and appropriately orientating the action of politics and managers, is thus a challenge for the next decades (Luoma and Rainbow, 2008).

Trace metals or metalloids (referred to trace elements hereafter) are among the most ubiquitous contaminants. Their remobilisation in sediments depends on the prevailing physicochemical conditions in both the sediment and water column, and on the biogeochemical processes occurring during the early diagenesis of sediment: biogeochemical reactions (e.g., sorption, (co)precipitation, dissolution) and physical (e.g., diffusion, advection) or biological (e.g., bioirrigation, bioturbation) transport mechanisms. Biogeochemical reactions, primarily controlled by microbial mineralization of organic matter, can increase the concentration of trace elements in porewater, and transport mechanisms can induce their transfer to the water column. Trace element fluxes at the sediment-water interface (SWI) have been observed in coastal areas, but their direction and intensity vary among sites and elements (e.g., Point et al., 2007). Among the factors influencing the intensity of the fluxes at the SWI, the oxygen concentrations in the water column was often identified as the most important one because it influences all of the biogeochemical characteristics of sediments (Middelburg and Levin, 2009). A low oxygen concentration in the water column has been found to enhance the flux of $\mathrm{Fe}, \mathrm{Mn}, \mathrm{As}, \mathrm{Co}, \mathrm{Hg}$ and $\mathrm{MeHg}$ from sediment to the water column (e.g. Sundby et al., 1986; Emili et al., 2011), whereas a high oxygen concentration can enhance the flux of $\mathrm{Cu}$ from the water column to the sediment (Riedel et al., 1997). The oxygenation of the water column also strongly influences the fluxes of other species important for environmental quality such as $\mathrm{\Sigma PO} 4, \mathrm{NO} 3-, \mathrm{NH} 4+$ and $\mathrm{H} 2 \mathrm{~S}$. For example, under hypoxic or anoxic conditions, fluxes of $\Sigma \mathrm{PO} 4, \mathrm{H} 2 \mathrm{~S}$ and $\mathrm{NH} 4+$ to the water column and fluxes of NO3- to the sediment are usually observed whereas in oxic conditions these fluxes tend to stop or reverse (Sundby et al. 1986; Middelburg and Levin, 2009; Emili et al., 2011). 
The influence of the oxygen concentration of the water column on reactive processes in the sediment and fluxes at the SWI is still poorly understood, especially in areas where the oxygen concentration of the water column oscillates seasonally (Morse and Eldridge, 2007). Furthermore, the increasing number of coastal areas subject to seasonal or permanent hypoxic episodes in recent decades (Diaz and Rosenberg, 2008) heightens the importance of understanding the diagenetic processes and fluxes at the SWI under hypoxic conditions.

The objective of this work is to study the main diagenetic reactions controlling the mobility of trace elements and nutrients in sediments and their exchange at the SWI under varying water column oxygen conditions using a method that has been successfully used in many different aquatic environments (Gallon et al., 2004; Merrit and Amirbahman, 2007; Couture et al., 2010); it consists of two complementary approaches: 1) one-dimensional steady-state inverse modelling of transport-reaction processes in porewater and 2) thermodynamic calculations (speciation and saturation indices). This method is applied here on the most extensive database of its kind, to our knowledge, which, for the first time, is applied to several trace metals (As, $\mathrm{Co}, \mathrm{Cr}, \mathrm{Hg}, \mathrm{MeHg}, \mathrm{Ni}$ ), nutrients and main chemical species collected at one site under two contrasting water column oxygen conditions and at a second site with oxic condition and macrobenthic organisms.

The study area is the Berre Lagoon (Southeast, France), a heavily industrialised coastal lagoon that received significant inputs of contaminants during the previous decades. These inputs have been regulated since the 1970's, but the concentrations of contaminant in surface sediments remain high (Rigaud et al., 2011). This lagoon also receives freshwater inputs from a hydroelectric power plant, causing a strong haline stratification of the water column and seasonal anoxic conditions in the deepest part of the lagoon. In the future, this freshwater release may be reduced or stopped, that may allow the destratification of the water column and the disappearance of these anoxic conditions. Such a change will certainly have a strong influence on the trace elements and nutrient exchanges at the SWI, which must be evaluated.

In this context, the objectives of this paper are (i) to identify the main biogeochemical reactions controlling trace element mobility in the sediments of the Berre Lagoon under different water column oxygen concentrations, (ii) to quantify trace element and nutrient exchanges at the SWI and (iii) to predict the influence on these processes an fluxes of the reoxygenation of the water column in the deepest part of the lagoon.

\section{Material and methods}

\subsection{Sampling}

Two sampling sites were examined in this work: site $V$ located in the Vaïne basin, which had a generally well-oxygenated water column, and site CB located in the southern part of the Central basin, where anoxic/hypoxic events occurred in the benthic water (Fig. 1, Table 1). Benthic organisms are permanently absent at site $\mathrm{CB}$ due to the occurrence of anoxic events. Site $\mathrm{V}$ was sampled in June 2010 during oxic conditions $\left(\mathrm{V}-\mathrm{O},\left[\mathrm{O}_{2}\right]=4.6 \mathrm{mg} . \mathrm{L}^{-1}\right.$; i.e. $60 \%$ of saturation). Site CB was sampled on two occasions, in summer 2009 during anoxic conditions $\left(\left[\mathrm{O}_{2}\right]<0.2 \mathrm{mg} \cdot \mathrm{L}^{-1} ;<3 \%\right.$ of saturation) and in summer 2010 during slight oxic conditions $\left(\left[\mathrm{O}_{2}\right]=2.9 \mathrm{mg} \cdot \mathrm{L}^{-1} ; 38 \%\right.$ of saturation), hereafter referred to as $\mathrm{CB}-\mathrm{A}$ and $\mathrm{CB}-\mathrm{O}$, respectively.

Three sediment cores were collected by divers using polycarbonate tubes (inner diameter 9.4 $\mathrm{cm}$ ), placed in refrigerated container, transported to the laboratory and processed within two hours. Eh were measured by inserting probes directly into the sediment through holes in one specific predrilled tube; these holes were covered with tape during sampling. One core, 
dedicated to solid phase characterisation, was sliced at $0.5 \mathrm{~cm}$ intervals (from 0 to $1 \mathrm{~cm}$ ), 1 $\mathrm{cm}$ intervals (from 1 to $5 \mathrm{~cm}$ ) and $2 \mathrm{~cm}$ intervals (from $5 \mathrm{~cm}$ to the end, up to $30 \mathrm{~cm}$ ) and the slices were placed in polyethylene tubes, freeze-dried and sieved through $63 \mu \mathrm{m}$ sieve to remove shells and broken shells. In order to minimize the oxidation of the solid phase, sediment cores were sliced in a glove box under $\mathrm{N}_{2}$ atmosphere and the solid phase was kept in closed vials until the freeze-drying step. One core was collected for $\mathrm{O}_{2}$ profiles measurements by microelectrodes within two hours after collection.

Porewater and overlying waters were collected using dialysis samplers (peepers) consisting of two columns of 50 horizontal cells with $1 \mathrm{~cm}$ vertical resolution drilled in a methacrylate casing. Prior to deployment, the peepers were immersed in a $10 \% \mathrm{HNO}_{3}$ solution for three days, rinsed and filled with ultrapure water, covered with a $0.45 \mu \mathrm{m}$ polycarbonate filter membrane and then stored for three weeks in a water-saturated $\mathrm{N}_{2}$ atmosphere to ensure complete removal of oxygen. The peepers were inserted into the sediment by divers and left in place for at least three weeks. Upon retrieval, the water in each cell was collected and filtered through a $0.2 \mu \mathrm{m}$ cellulose acetate filter. This step was carried out on field within one hour after peeper retrieval. During the 2010 field campaign (sites CB-O and V-O), two peepers were deployed, and the water samples were aliquoted for chemical analysis. During the summer 2009 field campaign (site CB-A), four peepers were deployed, and the subsampling plan was slightly modified for the additional analysis of three distinct profiles of $\mathrm{Hg}$ and $\mathrm{MeHg}$ concentrations.

\subsection{Analysis}

\subsubsection{Solid Phase Properties}

Sediment grain size was measured using laser granulometry (LS13320, Beckman coulter) following the elimination of organic matter through combustion in an oven at $450^{\circ} \mathrm{C}$ for $4 \mathrm{~h}$ and sample dispersion into defloculant $\left(\left(\mathrm{NaPO}_{3}\right)_{6}, 3 \%\right.$ ). Sediment water content was determined from mass differences between fresh and freeze-dried sediments and porosity was assessed following correction for salt content and shells (grain size fraction $>2 \mathrm{~mm}$ ) and assuming a sediment density of $2.65 \mathrm{~g} \mathrm{~cm}^{-3}$. The main mineralogical composition of the sediment was obtained using X-ray diffraction (X'Pert PRO, Panalytical).

An aliquot of freeze-dried and $<63 \mu \mathrm{m}$ sieved sediment was completely digested in a Teflon bomb in a microwave oven (Mars5, SEM) with an ultrapure $\mathrm{HF}, \mathrm{HCl}$ and $\mathrm{HNO}_{3}$ mixture. Following digestion, the acids were evaporated to near-dryness and the residues were recovered in $\mathrm{HNO}_{3} 2.5 \%$ and analysed for major ( $\mathrm{Ca}, \mathrm{Mg}, \mathrm{S}, \mathrm{P}, \mathrm{Al}, \mathrm{Fe}$ and $\mathrm{Mn}$ ) and trace (As, $\mathrm{Co}, \mathrm{Cr}, \mathrm{Ni}$ ) elements using ICP-AES (Ultima-C, Jobin Yvon, Horiba) and ICP-MS (Thermo Scientific X Series II), respectively.

The most reactive fraction of the major and trace elements was determined using ascorbate extraction (reductive dissolution) on freeze-dried sediments (Kostka and Luther; 1994). Extractions were carried out at room temperature $\left(24^{\circ} \mathrm{C}\right)$ on $100 \mathrm{mg}$ of freeze-dried sediment in $10 \mathrm{~mL}$ of $\mathrm{N}_{2}$-degassed ascorbate reagent $(\mathrm{pH} 8)$ for $24 \mathrm{~h}$ under continuous shaking. The ascorbate extracts were analysed using ICP-AES or ICP-MS.

Elemental analyses in solutions were performed using calibration solutions prepared with the same matrix as the samples $\left(\mathrm{HNO}_{3} 2.5 \%\right.$ or ascorbate). Blanks were always below $5 \%$ of the samples concentrations. Average analytical accuracies, estimated for the total sediment digestion of reference sediments SGR-1, MAG-1 (USGS) and STSD-3 (CCRMP) and MAG-1 (USGS), were always within $5 \%$ for $\mathrm{Ca}, \mathrm{Mg}, \mathrm{K}, \mathrm{S}, \mathrm{P}, \mathrm{Al}, \mathrm{Fe}, \mathrm{Mn}, \mathrm{As}$ and $\mathrm{Ni}$ and approximately $10 \%$ for Co and Cr.

Total $\mathrm{Hg}\left(\mathrm{Hg}_{\mathrm{tot}}\right)$ and $\mathrm{MeHg}$ concentrations were obtained for freeze-dried sediments using, respectively, a cold vapour atomic absorption spectrophotometer (AMA 254, Altec) and GC- 
ICP-MS (GC-Focus with X-series, Thermo Electron) following the protocol described by AbiGhanem et al., (2011). The analytical accuracies were obtained using reference sediments, MESS-2 (NRCC) for $\mathrm{Hg}$ and IAEA-405 (IAEA) for $\mathrm{MeHg}$, and were $<3 \%$ for total $\mathrm{Hg}$ and approximately $5 \%$ for $\mathrm{MeHg}$.

Total organic carbon (TOC) and total inorganic carbon (TIC) concentrations were measured on a Leco 125 CS analyser using the protocol described by Etcheber et al., (1999). Total nitrogen $\left(\mathrm{N}_{\text {tot }}\right)$ concentrations were analysed on a CHN Leco. All measurements performed on freeze-dried solid phase samples were corrected for salt content.

\subsubsection{Oxygen profiles measurements by microelectrodes}

Oxygen profiles measurements by microelectrodes were carried out at in situ temperature and $\mathrm{O}_{2}$ concentration into the overlying water column was adjusted to in situ conditions by bubbling an air- $\mathrm{N}_{2}$ mixing into the water column. Profiles were measured at $100 \mu \mathrm{m}$ depth increments with a Clark-type $\mathrm{O}_{2}$ microelectrode (OX50, Unisense, Denmark) equipped with an internal reference and a guard cathode. The sensor tip diameter was $50 \mu \mathrm{m}$, the $90 \%$ response time was $<5 \mathrm{~s}$, and the stirring sensitivity was < 1s. Microelectrodes were connected to a high-sensitivity picoamperemeter (PA2000, Unisense) via an A/D converter and were mounted on a motor controlled micromanipulator (MC-232, Unisense). Linear calibrations were done between the bottom water oxygen content precisely determined by a Winkler titration, and the zero oxygen in the anoxic part of the sediment. Up to 10 steadystate $\mathrm{O}_{2}$ profiles were randomly performed at each site in the collected sediment core to account for spatial heterogeneities. The position of the sediment-water interface was determined from a break in the oxygen concentration gradient. After profiles measurements, the core was sliced every $0.2 \mathrm{~cm}$ over the first $\mathrm{cm}$, and then every $0.5 \mathrm{~cm}$ down to $2 \mathrm{~cm}$ for porosity measurements. Oxygen profiles were processed using the $\mathrm{PRO}_{2} \mathrm{FLUX}$ program software (Deflandre and Duchêne, 2010).

\subsubsection{Dissolved Phase Analysis}

Water samples were analysed for $\mathrm{Na}, \mathrm{Ca}$ and $\mathrm{Mg}$ using ICP-AES (Ultima-C, Jobin Yvon, Horiba) and for $\mathrm{Fe}, \mathrm{Mn}, \mathrm{As}, \mathrm{Co}, \mathrm{Cr}$ and Ni using ICP-MS (Agilent 7700x equipped with HMI kit). The accuracies were checked using a seawater reference NASS-4 (NRCC) enriched with trace elements to achieve concentration ranges similar to the samples. The accuracies of the measurements were within $5 \%$ for $\mathrm{Na}, \mathrm{Ca}, \mathrm{Mg}, \mathrm{Fe}, \mathrm{Mn}, \mathrm{Co}, \mathrm{Ni}$ and $\sim 10 \%$ for As and Cr.

Total dissolved $\mathrm{Hg}\left(\mathrm{Hg}_{\mathrm{tot}}\right)$ concentrations were determined using cold vapour atomic fluorescence spectrometry (CVFAS, Tekran). The accuracies were confirmed using the reference material ORMS-4 (NRCC) and were approximately 5\%. The analysis of dissolved $\mathrm{MeHg}$ was performed using atomic fluorescence spectrophotometry following the protocol developed by Tseng et al. (1998).

The $\mathrm{pH}$ measurement and the analysis of total alkalinity, and $\mathrm{SO}_{4}{ }^{2-}, \Sigma \mathrm{H}_{2} \mathrm{~S}$ and $\Sigma \mathrm{PO}_{4}$ concentrations were performed using spectrophotometry (V-650 UV-VIS spectrophotometer, Jasco) following Metzger et al. (2007). Dissolved organic carbon (DOC) concentrations were determined on a TOC-V CHS analyser, Shimadzu. Total inorganic carbon concentrations, $\mathrm{tCO}_{2}\left(\mathrm{CO}_{2}, \mathrm{HCO}_{3}{ }^{-}\right.$and $\left.\mathrm{CO}_{3}{ }^{2-}\right)$, were obtained from the total alkalinity measurement, $\mathrm{pH}$ value and the concentrations of all of the species included in the definition of total alkalinity $\left(\mathrm{B}(\mathrm{OH})_{4}^{-}, \mathrm{H}_{3} \mathrm{SiO}_{4}{ }^{-}, \mathrm{H}_{2} \mathrm{SiO}_{4}{ }^{2-}, \mathrm{H}_{3} \mathrm{PO}_{4}, \mathrm{HPO}_{4}{ }^{2-}, \mathrm{PO}_{4}{ }^{3-}, \mathrm{NH}_{3}, \mathrm{HS}^{-}, \mathrm{HSO}_{4}^{-}, \mathrm{H}^{+}, \mathrm{OH}^{-}\right.$and $\left.\mathrm{DOC}\right)$, which were obtained by direct analysis, assessed from salinity and/or thermodynamic calculations (see below). $\mathrm{NH}_{4}{ }^{+}$and $\Sigma \mathrm{NO}_{3}\left(\mathrm{NO}_{3}{ }^{-}+\mathrm{NO}_{2}{ }^{-}\right)$concentrations were measured by flow injection analysis (FIA) following the methods developed by Hall and Aller (1992) for $\mathrm{NH}_{4}{ }^{+}$and Anderson (1979) for $\Sigma \mathrm{NO}_{3}$. 


\subsection{Thermodynamic Calculations}

The speciation of dissolved species in interstitial and overlying water was calculated through the consecutive use of two geochemical speciation codes: WHAM-VI (Tipping et al., 1998) and PHREEQC (Parkhurst and Appelo, 1999). This approach benefits from the specific strengths of each code, namely the calculation of the complexation among the trace elements and the dissolved organic ligands (WHAM-VI) and of redox equilibrium and saturation index $(\mathrm{SI})$ calculation (PHREEQC). The method includes 3 successive steps: 1) the speciation of the trace elements with fulvic acids (FA) and humic acids (HA) is calculated using WHAM-VI; 2) the apparent thermodynamic constants $\left(\mathrm{K}_{\mathrm{app}}\right)$ of the complexation of the trace elements with $\mathrm{HA}$ and FA are calculated (electronic annex EA-2) and integrated into the MINTEQ database (used as a database for PHREEQC); and 3) the speciation of the trace elements and their saturation index with respect to the mineral phases are calculated by the software PHREEQC.

Prior to the calculation, the MINTEQ and WHAM-VI default databases were completed from the thermodynamic constants given in electronic annexes EA-3 and EA-4. The input parameters used for WHAM-VI were the $\mathrm{pH}$ and total dissolved concentrations in $\mathrm{HA}, \mathrm{FA}, \mathrm{Cl}$, $\mathrm{Na}, \mathrm{Mg}, \mathrm{K}, \mathrm{SO}_{4}, \mathrm{tCO}_{2}, \mathrm{PO}_{4}, \mathrm{HS}, \mathrm{NH}_{4}, \mathrm{NO}_{3}, \mathrm{Fe}, \mathrm{Mn}, \mathrm{As}, \mathrm{Co}, \mathrm{Cr}, \mathrm{Ni}, \mathrm{Hg}$ and $\mathrm{MeHg}$. The concentrations of FA and HA were estimated from a ratio organic matter/DOC of 2/1 (Buffle, 1988) and an FA/HA ratio of 9/1 (Malcolm, 1985). The concentrations of $\mathrm{Cl}^{-}$and $\mathrm{K}^{+}$were estimated from measurements of $\mathrm{Na}$ and Dittmar's principle. For PHREEQC calculations, the redox potential Eh was added as input parameter and redox couples in the database were de-coupled to allow redox disequilibrium to occur.

\section{Résults}

\subsection{Solid Phase}

\subsubsection{Total Sediment Characteristics}

The sediments of the three cores consist of $51-81 \%$ silt $(2-63 \mu \mathrm{m}), 13-28 \%$ clay $(<2 \mu \mathrm{m})$ and $<20 \%$ of fine sands $(63-250 \mu \mathrm{m})$. The grain size fraction $>2 \mathrm{~mm}$ (mainly shells or shell fragments) is absent in CB-O and CB-A and is $<15 \%$ dry weight in V-O. The fraction on which the analyses were performed $(f<63 \mu \mathrm{m})$ is constant along the profiles in the three cores (silt: $81 \pm 3 \%$ at sites CB-A and CB-O and $85 \pm 1 \%$ at site $V$ ). The mineral composition is similar among sites and along the profile with the predominance of calcite and aragonite, quartz, pyrite $\left(\mathrm{FeS}_{2}\right)$, muscovite $\left(\mathrm{KAl}_{2}\left[(\mathrm{OH}, \mathrm{F})_{2} \mathrm{IAISi}_{3} \mathrm{O}_{10}\right]\right)$ and small proportions of dolomite $\left(\mathrm{CaMg}\left(\mathrm{CO}_{3}\right)_{2}\right)$.

The major element concentrations of sediments are relatively homogeneous with depth and similar in the three cores: TIC $(4.8 \pm 0.4 \%)$, Ca $\left(150 \pm 16 \mathrm{mg}^{-1}\right), \mathrm{Al}\left(39 \pm 9 \mathrm{mg}^{-1}\right)$, Fe $(21 \pm 2$ $\left.\mathrm{mg} \cdot \mathrm{g}^{-1}\right), \mathrm{S}\left(13 \pm 2 \mathrm{mg} \cdot \mathrm{g}^{-1}\right), \mathrm{Mg}\left(9 \pm 1 \mathrm{mg} \cdot \mathrm{g}^{-1}\right)$ and $\mathrm{Mn}\left(0.37 \pm 0.07 \mathrm{mg}^{-1} \mathrm{~g}^{-1}\right.$ (examples in Fig. 2a-f). However, depth profiles of TOC, $N_{\text {tot }}$ and $P_{\text {tot }}$ show concentration maxima at the surface. Significantly higher TOC and $\mathrm{N}_{\text {tot }}$ concentrations are observed at $\mathrm{V}-\mathrm{O}$ (Fig. 2a-b).

Trace element concentrations vary greatly with depth, and most of trace elements are at high concentrations a few centimetres below the SWI: the highest $\mathrm{As}$ and $\mathrm{Hg}_{\text {tot }}$ concentrations occurs at approximately $-15 \mathrm{~cm}$ at sites CB-O and CB-A and at $20-25 \mathrm{~cm}$ at site V-O, and the highest $\mathrm{Co}, \mathrm{Cr}$ and $\mathrm{Ni}$ concentrations occur at $-10 \mathrm{~cm}$ at site $\mathrm{V}-\mathrm{O}$ (Fig. $2 \mathrm{~g}-\mathrm{j}$ ). $\mathrm{MeHg}$, only analysed at CB-A, is at the highest concentrations at the SWI.

A comparison of the trace elements concentrations with the natural geochemical background for the area (Rigaud et al., 2011) shows that $\mathrm{Hg}$ and As at the three sites and $\mathrm{Cr}$ at site $\mathrm{V}-\mathrm{O}$ are strongly enriched in the sediment (e.g., up to 14 times the natural geochemical 
background for $\mathrm{Hg}$ at sites $\mathrm{CB}-\mathrm{A}$ and $\mathrm{CB}-\mathrm{O}$, Fig. 2j). These enrichments are due to the significant releases into the lagoon in the past, whereas their decrease in the upper part of the sediment cores reflects the establishment of industrial regulations (Rigaud et al., 2011).

\subsubsection{Reactive Fraction of the Solid Phase}

Ascorbate extractions give the primary information on the main oxidised phases, such as reactive $\mathrm{Fe}$ or $\mathrm{Mn}$ oxy-hydroxides (referred hereafter to $\mathrm{Fe}(\mathrm{OH})_{3}$ and $\mathrm{MnO}_{2}$ for simplicity) that are both oxidants for the mineralisation of organic matter and bearing phases for trace elements (e.g., Burdige, 1993). However, the contribution of other phases, such as FeS oxidised during sample handling is not excluded (Anshutz et al., 1998). In the 3 cores, the concentrations Fe extracted by ascorbate $\left(\mathrm{Fe}_{\mathrm{ASC}}\right.$, Fig. $\left.3 \mathrm{a}\right)$ are the highest at the SWI and decline sharply toward $-3 \mathrm{~cm}$. They remain relatively low and constant at deeper levels in the $\mathrm{CB}-\mathrm{O}$ and $\mathrm{CB}-\mathrm{A}$ cores. However, in $\mathrm{V}-\mathrm{O}$ core, the $\mathrm{Fe}_{\mathrm{ASC}}$ concentrations are two times greater than in the $C B$ cores and decrease slightly with depth until $-12 \mathrm{~cm}$.

Surface sediment enrichments in reactive $\mathrm{Mn}$ extracted by ascorbate $\left(\mathrm{Mn}_{\mathrm{ASC}}, \mathrm{Fig} .3 \mathrm{~b}\right)$ are found in the CB-A and $\mathrm{V}-\mathrm{O}$ cores but not in CB-O. As observed for $\mathrm{Fe}_{\mathrm{ASC}}, \mathrm{Mn}_{\mathrm{ASC}}$ is also clearly more enriched at $\mathrm{V}-\mathrm{O}$. The concentrations of $\mathrm{Fe}_{\mathrm{ASC}}$ and $\mathrm{Mn}_{\mathrm{ASC}}$ and their relative proportion with respect to total $\mathrm{Fe}$ and $\mathrm{Mn}$ in surface sediment are summarised in Table 2.

The concentrations of $\mathrm{As}_{\mathrm{ASC}}, \mathrm{Co}_{\mathrm{ASC}}, \mathrm{Cr}_{\mathrm{ASC}}$ and $\mathrm{Ni}_{\mathrm{ASC}}$ broadly follow the pattern of their total concentrations in the sediments, with maximum values encountered where the highest total concentrations occurred (Fig. 3c-f). The proportions of the total elements extracted are large for As (up to $70 \%$ ) but smaller for Co $(<35 \%), \mathrm{Cr}$ and $\mathrm{Ni}(<20 \%)$. However $\mathrm{As}_{\mathrm{ASC}}, \mathrm{Co}_{\mathrm{ASC}}$, $\mathrm{Cr}_{\mathrm{ASC}}$ and $\mathrm{Ni}_{\mathrm{ASC}}$ are also highly enriched at the $\mathrm{SWI}$ at $\mathrm{V}-\mathrm{O}$. Although lower, significant enrichments are also observed at the SWI for $\mathrm{As}_{\mathrm{ASC}}, \mathrm{Ni}_{\mathrm{ASC}}$ at sites $\mathrm{CB}-\mathrm{A}$ and $\mathrm{CB}-\mathrm{O}$ and for $\mathrm{Co}_{\mathrm{ASC}}$ only at site $\mathrm{CB}-\mathrm{A}$. Interestingly, the concentrations of $\mathrm{CO}_{\mathrm{ASC}}$ are really low in the first centimetre of surface sediment at site CB-O.

\subsection{Porewater}

\subsubsection{Physicochemical Characteristics}

Salinity (electronic annex AE-1), estimated from the Dittmar's principle and measured $\mathrm{Na}$ concentrations (Fig. 5a), slightly decreases from the overlying water column to the sediment (21 to 18 at $\mathrm{V}-\mathrm{O}, 32$ to 30 at $\mathrm{CB}-\mathrm{O}$ and 36 to 30 at CB-A). Values of pH are relatively constant over the entire profile at each site: $7.53 \pm 0.03$ at CB-A, $7.91 \pm 0.09$ at $\mathrm{CB}-\mathrm{O}$ and $8.04 \pm 0.10$ at $\mathrm{V}-\mathrm{O}$ (electronic annex EA-1). Redox potential values were $>350 \mathrm{mV} / \mathrm{NHE}$ in the overlying water when oxygen was present (CB-O and $\mathrm{V}-\mathrm{O}$ ) and approximately $50 \mathrm{mV}$ during anoxic conditions (CB-A) (Table 1); they dropped very strongly at the SWI and remained constant at approximately $-200 /-220 \mathrm{mV}$ at sites CB-O and V-O below $-5 \mathrm{~cm}$ (electronic annex AE-1). At site CB-A where Eh measurements were not carried out, Eh was fixed to $200 \mathrm{mV}$.

\subsubsection{Major Dissolved Species}

Oxygen penetration depth into the sediment (Fig. 4) varies from $0.45 \mathrm{~mm}$ at site CB-O to 2.0 $\mathrm{mm}$ at site $\mathrm{V}-\mathrm{O}$ where the occurrence of oxygen peaks are observed up to $4.6 \mathrm{~mm}$ depth. Concentrations of $\mathrm{Ca}, \mathrm{Mg}$ and $\mathrm{SO}_{4}{ }^{2-}$ decrease in the sediment compared with the overlying water. This decrease occurred directly at the SWI at CB-A and at $-5 \mathrm{~cm}$ at CB-O and V-O (Fig. 5b,c,e), depths that coincide with the appearance and increasing concentrations of $\Sigma \mathrm{H}_{2} \mathrm{~S}$. At site CB-A, $\Sigma \mathrm{H}_{2} \mathrm{~S}$ is also present in the water column $(\sim 100 \mu \mathrm{M})$. 
The concentrations of $\Sigma \mathrm{CO}_{2}, \Sigma \mathrm{PO}_{4}, \mathrm{NH}_{4}{ }^{+}$and $\mathrm{DOC}$ are constant and low in the water column, and increase sharply in the sediment from the SWI (at CB-A and V-O) or from $-5 \mathrm{~cm}$ (at CB$\mathrm{O}$ and $\mathrm{V}-\mathrm{O}$ for $\Sigma \mathrm{PO}_{4}$ ) (Fig. $\left.5 \mathrm{~d}, \mathrm{i}, \mathrm{j}, \mathrm{I}\right)$. Note that the porewater concentrations of DOC and $\Sigma \mathrm{NH}_{4}{ }^{+}$ at $\mathrm{V}-\mathrm{O}$ are significantly higher than those at the other sites. The $\Sigma \mathrm{NO}_{3}$ concentrations have maxima concentrations in the water column at $\mathrm{CB}-\mathrm{O}$ and $\mathrm{V}-\mathrm{O}$ and approach the detection limit in the sediments at the depth where $\mathrm{NH}_{4}{ }^{+}$appears. At CB-A, the $\Sigma \mathrm{NO}_{3}$ concentrations are always below the detection limit.

The Fe concentrations at CB-A are highest in the anoxic water column $(0.8-1.45 \mu \mathrm{M}$, maximum values just above the SWI) and decrease sharply in the sediment down to the limit of detection (Fig. $5 \mathrm{~g}$ ). At CB-O and V-O, the opposite is observed, with concentrations in the oxygenated water column near the limit of detection and relatively high concentrations in the porewater, which are characterised by two peaks at $4 \mu \mathrm{M}$ at $-7 \mathrm{~cm}$ and $-2 \mathrm{~cm}(\mathrm{~V}-\mathrm{O})$ and a broad peak at $1 \mu \mathrm{M}$ between -9 and $-11 \mathrm{~cm}(\mathrm{CB}-\mathrm{O})$.

The profile of the Mn concentrations at site CB-O features a high peak reaching $30 \mu \mathrm{M}$ in the first $4 \mathrm{~cm}$ below the SWI and relatively high concentrations in the water column $(5-10 \mu \mathrm{M})$ (Fig. 5h). At this site, the Mn peak is located above the Fe peak. The Mn profile at CB-A is very similar but with lower concentrations (peak at $2.4 \mu \mathrm{M}$ in the first $3 \mathrm{~cm}$ below the SWI and concentration in the water column of $1.5 \mu \mathrm{M}$ ), but here, the peak of $\mathrm{Mn}$ is located below that of Fe. At V-O site, the Mn concentrations approach the limit of detection except around the SWI, where two peaks at $+2 \mathrm{~cm}(0.8 \mu \mathrm{M})$ and $-7 \mathrm{~cm}(8.5 \mu \mathrm{M})$ are present. For the three sites, the concentrations of $\mathrm{Mn}$ decreased with increasing depth to values close to the limit of quantification below $-20 \mathrm{~cm}$.

\subsubsection{Dissolved Trace Elements}

At sites $\mathrm{CB}-\mathrm{A}$ and $\mathrm{CB}-\mathrm{O}, \mathrm{As}$ and $\mathrm{Ni}$ concentrations are highest in the overlying water (As = 20-50 nM, Ni $=10-25 \mathrm{nM}$ ) and decrease under the SWI to $5-30 \mathrm{nM}$ and $4 \mathrm{nM}$, respectively (Fig. $5 \mathrm{~m}, \mathrm{p}$ ). However, As exhibits a reverse trend at site $\mathrm{V}-\mathrm{O}$ with minimum concentrations in the overlying water (10-20 nM) and an increase in the porewater (20-50 nM). At this site, Ni concentrations are rather stable over the entire profile, at approximately $15-25 \mathrm{nM}$.

The profiles of $\mathrm{Co}$ at $\mathrm{CB}-\mathrm{O}$ and $\mathrm{V}-\mathrm{O}$ are very similar to those of $\mathrm{Mn}$, with the highest concentrations in the first 4 centimetres below the SWI (up to $50 \mathrm{nM}$ ) at CB-O and at $+2 \mathrm{~cm}$ $(10 \mathrm{nM})$ and $-6 \mathrm{~cm}(8.5 \mathrm{nM})$ at $\mathrm{V}-\mathrm{O}$ (Fig. $5 \mathrm{n})$. However, the Co profile clearly differs from that of $\mathrm{Mn}$ at CB-A with minimum Co concentrations at the SWI (1 nM) and an increase with depth (up to $12 \mathrm{nM}$ ).

The concentrations profiles of $\mathrm{Cr}$ differ greatly among the three sites (Fig. 50). $\mathrm{Cr}$ concentrations are low $(<35 \mathrm{nM})$ throughout the profile at $\mathrm{CB}-\mathrm{O}$, more variables at $\mathrm{CB}-\mathrm{A}$ with maxima at the SWI $(90 \mathrm{nM})$ and $-12 \mathrm{~cm}(70 \mathrm{nM})$, and increase with depth at site V-O with a peak $(120 \mathrm{nM})$ at $-10 \mathrm{~cm}$.

The three concentrations profiles of total $\mathrm{Hg}\left(\mathrm{Hg}_{\mathrm{tot}}\right)$ and $\mathrm{MeHg}$ (site CB-A) are very similar to each other. They show maxima in the overlying water (10-20 pM and 6-11 pM, respectively), strong decreases below the SWI and reach the limit of quantification below $-5 \mathrm{~cm}$ (Fig. $5 \mathrm{q}, \mathrm{r}$ ). $\mathrm{MeHg}$ dominates the speciation of $\mathrm{Hg}$ with average proportions of $73 \pm 22 \%$ (range $32-108 \%$ ) in the porewater. 


\section{Discussion}

\subsection{Identification of the Main Biogeochemical Reactions}

The main early diagenetic reactions as well as those involving the trace elements considered in this work (Table 3) correspond to (i) the primary redox reactions (R1-R6) for the mineralisation of organic matter (OM), (ii) the secondary redox reactions (R7-R21) involving the products from the primary redox reactions and the remaining oxidants, (iii) the non-redox precipitation reactions (R22-R26) and (iv) the reactions controlling the trace element dynamics at the solid/liquid interface, and thus their mobility in the sediment (R27-R32) (e.g., Wang and Van Capellen, 1996).

The approach used here to identify and quantify the biogeochemical reactions controlling the remobilisation or immobilisation of trace elements and nutrients in sediments and their fluxes at the SWI is based on those recently used to determinate the dynamic of $\mathrm{Pb}$ (Gallon et al., 2004), $\mathrm{Hg}$ and $\mathrm{MeHg}$ (e.g., Merrit and Amirbahman, 2007) and As (Couture et al., 2010) in different aquatic environments.

First, the depth intervals where remobilisation or immobilisation reactions occurred in the sediments and the quantification of their net rates are obtained by inverse transport-reaction modelling of the concentration profiles of the species in the porewater. The mass conservation equation in one dimension of a dissolved species as proposed by Boudreau (1997) is

$$
\left(\frac{\partial \phi C}{\partial t}\right)=\frac{\partial}{\partial x}\left(\phi\left(D_{S}+D_{B}\right) \frac{\partial C}{\partial x}\right)-v \frac{\partial C}{\partial x}+\phi \alpha\left(C_{\infty}-C\right)+R_{n e t} \quad \text { (Equation 1) }
$$

where $C$ is the concentration $(\mu \mathrm{M})$ of a dissolved species at time $t(\mathrm{~s})$ and depth $x(\mathrm{~cm}$, set at SWI and negative below), $\phi$ is the porosity, $D_{S}\left(\mathrm{~cm}^{2} . \mathrm{s}^{-1}\right)$ is the molecular diffusion coefficient in the porewater, $D_{B}\left(\mathrm{~cm}^{2} . \mathrm{s}^{-1}\right)$ is the biodiffusion coefficient associated to the sediment reworking process, $v$ is the velocity of the advective flow in porewater $\left(\mathrm{cm} \mathrm{s}^{-1}\right), \alpha\left(\mathrm{s}^{-1}\right)$ is the bioirrigation rate coefficient, $C_{\infty}(\mu \mathrm{M})$ is the concentrations in the water column, and $R_{\text {net }}$ $\left(\mu \mathrm{mol} . \mathrm{L}^{-1} \cdot \mathrm{s}^{-1}\right)$ is the net rate of reactions, corresponding to the balance between the reactions of production or consumption of the species in the porewater.

Several hypotheses have been proposed to simplify this equation. First, we assume that the dissolved profiles are at a quasi-stationary state $(\partial \mathrm{C} / \partial \mathrm{t} \approx 0)$. Although this assumption is not completely valid in environments subject to changing conditions, it has been useful to explore the parameters responsible for the immobilisation or remobilisation of trace elements (e.g., Couture et al., 2010). Second, porewater advection due to sediment compaction (Peclet number, $\mathrm{Pe}<0.1$; Boudreau, 1997) is neglected $(v=0)$. Third, the recurrent anoxic conditions in the water column at site $\mathrm{CB}$ totally prevent the colonization of the sediment by benthic organisms (Fig. 1), and consequently, sediment reworking and bioirrigation are absent in CB$\mathrm{A}$ and $\mathrm{CB}-\mathrm{O}\left(D_{B}\right.$ and $\left.\alpha=0\right)$. Because the benthic faunal density in the Vainne basin is low $\left(<500\right.$ ind. $\mathrm{m}^{-2}$, GIPREB, com. pers.), biodiffusion and bioirrigation were also neglected at site $\mathrm{V}-\mathrm{O}$. This simplification has a negligible effect for the parameter $D_{B}$ that is generally at least an order of magnitude lower than $D_{S}$ (Schulz, 2006). However, not considering possible transport by bioirrigation (i.e.; assuming $\alpha=0$ ) could lead to an underestimation of the fluxes and reaction rates at site $\mathrm{V}-\mathrm{O}$, but such simplification doesn't impact the general discussion of process occurring in the sediment.

From these assumptions, Equation 1 is rewritten to express the net rates of reactions only as a function of the diffusion of dissolved species in the porewater (Equation 2).

$$
R_{n e t}=\frac{\partial}{\partial x}\left(\phi D_{S} \frac{\partial C}{\partial x}\right)
$$


Equation 2 was solved numerically using the code PROFILE (Berg et al., 1998), which yields positive $R_{\text {net }}$ values for species production in the porewater and negative for species consumption in the porewater. The values of $D_{s}$ are obtained from the coefficient of molecular diffusion in free water $D^{0}$ corrected for salinity, temperature and sediment tortuosity (Boudreau, 1997). For complexed species for which there are no $D^{\circ}$ data, the values for the free ion are used. For $\mathrm{Cr}$, which is predominantly complexed to the $\mathrm{OM}$, the $D^{0}$ of fulvic acid is used (Gallon et al., 2004).

Finally, the reactions involved in the remobilisation or immobilisation processes are identified assuming that if two species (dissolved or particulate) involved in a reaction in Table 3 are present in measurable concentrations at the same depth, the reaction is considered. In the specific case of an area where inverse modelling suggests that the consumption of a dissolved species $\left(R_{\text {net }}<0\right)$ is linked to solute transfer from the porewater to the particle, we take into account two processes: i) precipitation reaction is considered if thermodynamic calculations predict that a dissolved species reach saturation with respect to a mineral phase, ii) (ad)sorption and/or coprecipitation reactions are considered if thermodynamic calculations do not reveal any favourable precipitation reactions.

\subsection{Main Early Diagenetic Reactions}

\subsubsection{Evidence for OM mineralisation}

At the three sites, the decrease with depth of particulate TOC (Fig. 2a), in parallel with the increase of $\Sigma \mathrm{CO}_{2}, \mathrm{NH}_{4}{ }^{+}, \Sigma \mathrm{PO}_{4}$ and DOC porewater concentrations (Fig. $5 \mathrm{~d}$,i,j, I) directly reflect the mineralisation of OM during burial (R1 to R6, Table 3 ) and resulting redox reactions.

\subsubsection{Primary and secondary redox and precipitation reactions}

Measured and modelled porewater profiles of $\Sigma \mathrm{NO}_{3}, \mathrm{Fe}, \mathrm{Mn}, \mathrm{SO}_{4}{ }^{2-}, \mathrm{\Sigma H}_{2} \mathrm{~S}$ and the trace elements are presented in Fig. 6A, Fig. 7A and Fig. 8A. A schematic representation of the vertical distribution of the major and trace dissolved species in the porewater is also proposed for each site (Fig. 6B, Fig. 7B and Fig. 8B). The schematic representation reports (i) the relative concentrations, (ii) the areas of production and consumption, (iii) the reactions assumed to be involved (the numbers of reactions reported in Table 3), (iv) the net rates of reactions integrated over the depth interval $\left(R_{\text {net }}\right.$ in mol.cm $\left.{ }^{-2} \cdot \mathrm{s}^{-1}\right)$ and $(\mathrm{v})$ the significant diffusive fluxes at the SWI $\left(\mathrm{mol}_{\mathrm{cm}} \mathrm{cm}^{-2} \cdot \mathrm{s}^{-1}\right)$ and their direction. The main identified biogeochemical reactions and their locations in the sediment are summarised in Table 4.

At site $\mathrm{CB}-\mathrm{O}$ (Fig. 6), the reactions involved in the $\mathrm{OM}$ mineralisation are well resolved vertically and follow the theoretical sequence proposed by Froelich et al. (1979): consumption of $\mathrm{O}_{2}$ (within the first $0.45 \mathrm{~mm}$ ), $\Sigma \mathrm{NO}_{3}$ reduction (down to $-5.7 \mathrm{~cm}$ depth), $\mathrm{MnO}_{2}$ reduction $\left(0\right.$ to $-2.4 \mathrm{~cm}$ depth), $\mathrm{Fe}(\mathrm{OH})_{3}$ reduction $\left(-9.5\right.$ to $-11.9 \mathrm{~cm}$ depth) and $\mathrm{SO}_{4}{ }^{2-}$ reduction (-14.3 to $-28.6 \mathrm{~cm}$ depth). The intense $\mathrm{MnO}_{2}$ reduction below the $\mathrm{SWI}$ is consistent with the low reactive $\mathrm{Mn}_{\mathrm{AsC}}$ concentrations in the surface sediment (Table 2; Fig. 3b). The Mn produced in the porewater diffuses deeper into the sediment and is completely consumed between -2.4 and $-7.2 \mathrm{~cm}$. This consumption is not related to the precipitation of the usual $\mathrm{Mn}$ minerals, which are under-saturated (rhodochrosite, $\mathrm{MnCO}_{3}$, $\mathrm{SI}<-1$; $\mathrm{MnS}$ or haurite; $\mathrm{SI}$ $<-2$ ), but could rather be associated with the precipitation of another form of Mn carbonate or coprecipitation with carbonates (R31) as previously reported (e.g., Pingitore et al. 1988; Deflandre et al., 2002). The consumption of $\mathrm{Fe}$ between 0 and $-9.5 \mathrm{~cm}$ is associated with the precipitation of $\mathrm{Fe}(\mathrm{OH})_{3}(\mathrm{R} 14, \mathrm{R} 17)$, which contributes to the enrichment of $\mathrm{Fe}_{\mathrm{ASC}}$ at the SWI (Table 2; Fig. 3a). Such precipitation is furthermore supported by the saturation or oversaturation of $\mathrm{Fe}$ with respect to several $\mathrm{Fe}$ oxy-hydroxydes (hematite, magnetite, lepidocrocite, $\mathrm{SI} \geq 0$ ). More deeply in the porewater, $\mathrm{Fe}$ is rapidly consumed through $\mathrm{Fe}$ 
sulphide precipitation (R25). This is consistent with i) the saturation of the porewater with respect to pyrrhotite and troilite $(0<\mathrm{SI}<0.7)$; ii) the occurrence of pyrite, which requires for its formation an intermediate step involving Fe monosulphides (R25 + R26; Rickard and Morse, 2005); and iii) the significantly lower depth integrated production rate of $\Sigma \mathrm{H}_{2} \mathrm{~S}\left(\mathrm{R}_{\text {net }}=\right.$

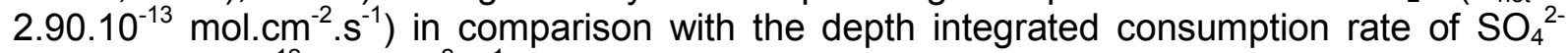
$\left(R_{\text {net }}=-2 \cdot 33 \cdot 10^{-12} \mathrm{~mol} \cdot \mathrm{cm}^{-2} \cdot \mathrm{s}^{-1}\right)$, indicating a loss of $S$ in the porewater.

At the same site under anoxic conditions (CB-A, Fig. 7), the only available oxidants for the mineralisation of $\mathrm{OM}$ are $\mathrm{MnO}_{2}, \mathrm{Fe}(\mathrm{OH})_{3}$ and $\mathrm{SO}_{4}{ }^{2-}$, whereas $\mathrm{O}_{2}$ and $\Sigma \mathrm{NO}_{3}$ are depleted above the SWI. In contrast with the oxic conditions, the reductions of these oxidants all occur at the SWI with the production of $\mathrm{Mn}(\mathrm{R} 3, \mathrm{R} 16$ and R18) between 0 to $-3.7 \mathrm{~cm}$ depth, the production of $\mathrm{Fe}(\mathrm{R} 4, \mathrm{R} 19, \mathrm{R} 20)$ being only noticeable at the SWI (a single data point that was not captured by PROFILE) and the consumption of $\mathrm{SO}_{4}{ }^{2-}$ (R5) between 0 and $-5.0 \mathrm{~cm}$ depth (Table 4). The modelled porewater Fe profile (Fig. 7A) displays a very high consumption rate between 0 and $-2 \mathrm{~cm}$ in depth, which is attributed to the precipitation of FeS (R25). The occurrence of this precipitation in surface sediment strongly suggest $i$ ) that the reduction of $\mathrm{Fe}(\mathrm{OH})_{3}$ and the precipitation of $\mathrm{FeS}$ both occur at the same depth and ii) that the kinetics of FeS precipitation dominates the reduction $\mathrm{Fe}(\mathrm{OH})_{3}$, hiding the production of Fe in porewater at the SWI. This explains the location of the Fe peak above the Mn peak.

At site $\mathrm{V}-\mathrm{O}$, where the overlying water is oxygenated and macrofauna are observed in the sediment, the identification of the reactions is more complex. Two overlapped diagenetic sequences can be observed (Fig. 8). The first sequence spans across the SWI and involves the reduction of $\Sigma \mathrm{NO}_{3}(\mathrm{R} 2$; between 0 and $+5 \mathrm{~cm})$ and $\mathrm{MnO}_{2}(\mathrm{R} 3, \mathrm{R} 16$; between +1 and +3 $\mathrm{cm}$ ) in the overlying water (not modelled by PROFILE) and the reduction of $\mathrm{Fe}(\mathrm{OH})_{3}(\mathrm{R} 4$; between 0 and $-4.2 \mathrm{~cm}$ depth) in the sediment porewater. The peak of $\Sigma \mathrm{NO}_{3}$ in the overlying water may be associated with the oxidation of $\mathrm{NH}_{4}{ }^{+}(\mathrm{R} 7, \mathrm{R} 16)$. The presence of $\mathrm{Fe}$ concentrations close to the detection limit in the overlying water indicate its precipitation as $\mathrm{Fe}(\mathrm{OH})_{3}$ at the SWI (R10, R14), which is consistent with the significant enrichment in $\mathrm{Fe}_{\mathrm{ASC}}$ in the surface sediment at this site (Table 2; Fig. 3a). The second diagenetic sequence occurs between -5.1 and $-26.2 \mathrm{~cm}$ and involves the reduction of $\mathrm{MnO}_{2}$ (from -5.1 to $-7.6 \mathrm{~cm}$ ), $\mathrm{Fe}(\mathrm{OH})_{3}$ (from -6.3 to $-8.4 \mathrm{~cm}$ ) and $\mathrm{SO}_{4}{ }^{2-}$ (from -6.6 to $-26.2 \mathrm{~cm}$ ). The Mn produced by the oxidation of the $\mathrm{OM}(\mathrm{R} 3), \mathrm{Fe}(\mathrm{R} 17)$ and $\Sigma \mathrm{H}_{2} \mathrm{~S}(\mathrm{R} 18)$ diffuses upward where it is reoxidised by $\mathrm{O}_{2}$ (R9) and/or $\mathrm{\Sigma NO}_{3}$ (R13) at the SWI (consistent with the accumulation of $\mathrm{MnO}_{2}$ in the surface sediment, Table 2), and downward, where it is co-precipitated with carbonates (R31). The Fe produced by the reduction of $\mathrm{Fe}(\mathrm{OH})_{3}$ by $\mathrm{OM}, \mathrm{NH}_{4}{ }^{+}$and/or $\Sigma \mathrm{H}_{2} \mathrm{~S}(\mathrm{R} 4, \mathrm{R} 19, \mathrm{R} 20)$ diffuses upward where it is oxidised as $\mathrm{Fe}(\mathrm{OH})_{3}$ by $\mathrm{MnO}_{2}(\mathrm{R} 17)$, and downward where it precipitates as Fe sulphides (R25). The presence of $\Sigma \mathrm{H}_{2} \mathrm{~S}$ up to $-3 \mathrm{~cm}$ depth can imply the precipitation of $\mathrm{FeS}(\mathrm{R} 25)$ in the same area where the Fe is produced. The presence of these two sequences can be explained by the activities of benthic organisms, which can mix the top few centimetres of sediment (sediment reworking) and/or modify the distribution of oxidized and reduced dissolved species near the SWI (bioirrigation). The occurrence of bioirrigation is illustrated by the $\mathrm{O}_{2}$ peaks observed up to $-0.4 \mathrm{~cm}$ under the SWI (Fig. 4).

\subsubsection{Carbonate precipitation}

The decreasing porewater salinity observed at the three sites (electronic annex EA-1) implies the decreasing concentrations of the major species of seawater. However, the decreases in the measured concentrations of $\mathrm{SO}_{4}{ }^{2-}, \mathrm{Ca}$ and $\mathrm{Mg}$ are greater than those expected from the decrease of salinity (calculated from the Dittmar's principle and $\mathrm{Na}$ concentrations, Fig. 9), suggesting a consumption of these elements in the sediments. As previously indicated, the consumption of $\mathrm{SO}_{4}{ }^{2-}$ is associated to its reduction for $\mathrm{OM}$ mineralisation. The consumption of $\mathrm{Ca}$ and $\mathrm{Mg}$ is attributed to the precipitation of carbonate minerals reaching saturation ( $\mathrm{S} \mid \geq 0.5$ for calcite, aragonite, magnesite, dolomite and huntite). The ratios of the PROFILE- 
calculated consumption rates of $\mathrm{Mg}$ to those of $\mathrm{Ca}$ are all greater than one $\left(\mathrm{R}_{\text {net }} \mathrm{Mg} / \mathrm{Ca}=\sim 3\right.$ for $\mathrm{CB}-\mathrm{O}, \sim 5$ for $\mathrm{V}-\mathrm{O}$ and $\sim 13$ for $\mathrm{CB}-\mathrm{A}$ ), indicating the predominance of $\mathrm{Mg}$ precipitation relative to $\mathrm{Ca}$ and thus the preferential authigenic formation of Mg-rich carbonates. This carbonate precipitation may be responsible for the Mn consumption in the porewater by coprecipitation as previously proposed.

\subsection{Reactions involved in the mobility of trace elements}

\subsubsection{Adsorption/Coprecipitation with $\mathrm{Fe}(\mathrm{OH})_{3}$}

At site CB-A, the strong relationship between the depth intervals of $\mathrm{Fe}(\mathrm{OH})_{3}$ reduction and the remobilisation of $\mathrm{As}, \mathrm{Cr}, \mathrm{Ni}, \mathrm{Hg}$ and $\mathrm{MeHg}$ (Fig. 7) is explained by the association of these species with $\mathrm{Fe}(\mathrm{OH})_{3}$ by adsorption and/or coprecipitation and by their remobilisation during the $\mathrm{Fe}(\mathrm{OH})_{3}$ reduction (R29). This is in accordance with the reported behaviour for As (Chaillou et al., 2003; Couture et al., 2010), Cr (Beck et al., 2008), Ni (Santos-Echeandia et al. 2009) and $\mathrm{Hg} / \mathrm{MeHg}$ (Hollweg et al., 2009) in sediment.

The association of these trace elements by adsorption and/or coprecipitation with $\mathrm{Fe}(\mathrm{OH})_{3}$ (R29) is further supported at $\mathrm{V}-\mathrm{O}$ by the As remobilisation that coincides with the depth interval where $\mathrm{Fe}(\mathrm{OH})_{3}$ is reduced $(-4.8$ and $-9.5 \mathrm{~cm})$ and in $\mathrm{V}-\mathrm{O}$ and $\mathrm{CB}-\mathrm{O}$ by the consumption of $\mathrm{As}, \mathrm{Ni}$ and $\mathrm{Cr}$ below the $\mathrm{SWI}$ where precipitation of $\mathrm{Fe}(\mathrm{OH})_{3}$ occurs. The association with $\mathrm{Fe}$ cycle rather than $\mathrm{Mn}$ cycle is furthermore supported by the enrichments of $\mathrm{As}_{\mathrm{ASC}}, \mathrm{Ni}_{\mathrm{ASC}}$ and, to a lesser extent, $\mathrm{Cr}_{\mathrm{ASC}}$ in the surface sediments at the three sites as observed for $\mathrm{Fe}_{\mathrm{ASC}}$, while it is not the case for $\mathrm{Mn}_{\mathrm{ASC}}$ that doesn't present any enrichment at site CB-O (Fig. 3). However, in the surface sediment at sites CB-A and CB-O, the extraction of a portion of As associated with the most reactive FeS or a portion of NiS (see below) can not be excluded.

Surprisingly, there is no remobilisation of As at the first peak of $\mathrm{Fe}$ at $\mathrm{V}-\mathrm{O}$. This observation also concerns $\Sigma \mathrm{PO}_{4}$ that presents a similar geochemical behavior (Mucci et al., 2000), which is also only remobilised at the second peak of Fe (Fig. 5i). The major difference between these two Fe peaks is that the former occurs in the presence of high concentrations of $\mathrm{Fe}(\mathrm{OH})_{3}\left(\mathrm{Table} 2\right.$, Fig. 3a). The absence of remobilisation of As and $\Sigma \mathrm{PO}_{4}$ in this area implies that both species are associated with a less reactive phase of $\mathrm{Fe}(\mathrm{OH})_{3}$, which is reduced deeper in the sediment under more anoxic conditions, as proposed by Mucci et al. (2000). Another possibility is that under high concentrations of $\mathrm{Fe}(\mathrm{OH})_{3}$, the kinetics of the remobilisation of $A s$ and $\Sigma \mathrm{PO}_{4}$ during the gradual dissolution of $\mathrm{Fe}(\mathrm{OH})_{3}$ are lower than their kinetics of readsorption onto the remaining $\mathrm{Fe}(\mathrm{OH})_{3}$ phase. A second surprising observation concerns the absence of $\mathrm{Cr}$ and Ni remobilisation during $\mathrm{Fe}(\mathrm{OH})_{3}$ reduction at site $\mathrm{CB}-\mathrm{O}$ and of $\mathrm{Cr}$ and $\mathrm{Ni}$ at site $\mathrm{V}-\mathrm{O}$, which will be discussed in more detail in the following section.

The net reaction rates calculated for As remobilisation during $\mathrm{Fe}(\mathrm{OH})_{3}$ reduction $\left(4.4 .10^{-17}\right.$ mol.cm $\mathrm{cm}^{-3} \cdot \mathrm{s}^{-1}$ and $0.6 \cdot 10^{-17} \mathrm{~mol} . \mathrm{cm}^{-3} \cdot \mathrm{s}^{-1}$ for CB-A and V-O, respectively) or consumption during $\mathrm{Fe}(\mathrm{OH})_{3}$ precipitation $\left(-0.85 .10^{-17} \mathrm{~mol}^{-\mathrm{cm}^{-3}} \cdot \mathrm{s}^{-1}\right.$ at $\left.\mathrm{V}-\mathrm{O}\right)$ are very similar to those reported using the same modelling approach in Canadian lakes: between $1.2 .10^{-17}$ and $7.1 .10^{-17} \mathrm{~mol} . \mathrm{cm}^{-3} \cdot \mathrm{s}^{-1}$ for net remobilisation rates and between $-0.5 \cdot 10^{-17}$ and $-5.3 .10^{-17} \mathrm{~mol} . \mathrm{cm}^{-3} . \mathrm{s}^{-1}$ for net consumption rates (Couture et al. 2010).

\subsubsection{Adsorption/Coprecipitation with $\mathrm{MnO}_{2}$}

Among the trace elements studied, only Co demonstrates a clear link with the Mn cycle, as previously reported in other aquatic environments (Canavan et al., 2007, Stockdale et al., 2010). Where $\Sigma \mathrm{H}_{2} \mathrm{~S}$ is absent, areas of Co remobilisation correspond exactly to those where $\mathrm{MnO}_{2}$ is reduced (Fig. 6; Fig. 8), supporting a strong coupling between Co and $\mathrm{MnO}_{2}$ by adsorption and/or coprecipitation (R30). In the water column at site $\mathrm{V}-\mathrm{O}$, remobilised Co 
diffuses downward and upward and is immediately trapped by readsorption and/or coprecipitation with $\mathrm{MnO}_{2}$. At CB-O, the strong Co remobilisation below the SWI could explain its depletion in the first centimetres of the solid phase sediment $\left(\mathrm{Co}_{\mathrm{AsC}}\right.$, Fig. $\left.3 \mathrm{~d}\right)$. However, in presence of $\Sigma \mathrm{H}_{2} \mathrm{~S}$, the affinity between Mn and Co appears to be somewhat altered.

\subsubsection{Reactions with sulphides}

At the three studied sites, excluding the particular case of $\mathrm{Cr}$ discussed in the last section, the trace elements diffuse downward from the depth interval where they are remobilised and are consumed in the deeper layers of sediment where sulphide is present (Fig. 6-8). In a sulphidic environment, the mobility of trace elements is greatly reduced in association with the formation of insoluble sulphide (e.g., Huerta-Diaz et al. 1998; Morse and Luther, 1999). The main processes involved in this immobilisation are direct metal sulphide precipitation or adsorption onto $\mathrm{FeS} / \mathrm{FeS}_{2}$.

At the three sites, when $\Sigma \mathrm{H}_{2} \mathrm{~S}$ is present, the thermodynamic calculations predict that the porewater concentrations of $\mathrm{Ni}$ and $\mathrm{Co}$ are at equilibrium with respect to $\mathrm{NiS} \beta(0<\mathrm{SI}<1)$ and $\operatorname{CoS} \beta(\mathrm{SI} \sim 0)$. Therefore, in the Berre Lagoon sediment, the precipitation of CoS and NiS clearly controls the mobility of $\mathrm{Ni}$ and $\mathrm{Co}$ in the sulphidic porewater (R27). The absence of $\mathrm{Ni}$ remobilisation during $\mathrm{Fe}(\mathrm{OH})_{3}$ reduction at $\mathrm{CB}-\mathrm{O}$ and $\mathrm{V}-\mathrm{O}$ indicates that the precipitation of $\mathrm{NiS}$ could kinetically dominate the reactions of remobilisation of $\mathrm{Ni}$. In this case, the speciation of $\mathrm{Ni}$ in the solid phase would evolve during sediment burial from an adsorption onto $\mathrm{Fe}(\mathrm{OH})_{3}$ to an association with sulphides, without any significant remobilisation in the pore water. For Co, kinetic competition between its remobilisation during $\mathrm{MnO}_{2}$ reduction (R30, cf section 4.3.2.) and CoS precipitation (R27) can be observed. Indeed, two areas are identified where $\mathrm{MnO}_{2}$ reduction occurs in the presence of $\Sigma \mathrm{H}_{2} \mathrm{~S}$ : between 0 and $-2.4 \mathrm{~cm}$ at CB-A (Fig. 7) and between -5 and $-10 \mathrm{~cm}$ at $\mathrm{V}-\mathrm{O}$ (Fig. 8). At CB-A, a high consumption rate of $\mathrm{Co}$ is observed at the same depth, indicating that the kinetics of precipitation of CoS clearly dominate those of Co remobilisation during $\mathrm{MnO}_{2}$ reduction. At the site $\mathrm{V}-\mathrm{O}$, a different situation is observed because Co production rate is very low. In this latter case, we assumed that the remobilisation of Co dominates but is greatly limited by its reprecipitation in the form of CoS.

In contrast with $\mathrm{Co}$ and $\mathrm{Ni}$, the PROFILE-predicted porewater consumptions in sulphidic sediments of As at sites CB-A and $\mathrm{V}-\mathrm{O}$ and of $\mathrm{Hg}$ and $\mathrm{MeHg}$ at site CB-A cannot be attributed to the precipitation As or $\mathrm{Hg}$ sulphides nor to discrete minerals forms of $\mathrm{As}$ or $\mathrm{Hg}$, since their porewater concentrations are all largely undersaturated with respect to the mineral tested (e.g., SI of realgar, orpiment and $\mathrm{Mg}_{3}\left(\mathrm{AsO}_{4}\right)_{2}<-5$; SI of metacinnabar or cinnabar <2). Alternatively, these patterns could be explained by the adsorption and/or coprecipitation of As and $\mathrm{Hg} / \mathrm{MeHg}$ with $\mathrm{FeS}$ or $\mathrm{FeS}_{2}$ (R28). According to the high proportion of $\mathrm{MeHg}$ $(73 \pm 22 \%)$ within the dissolved $\mathrm{Hg}_{\text {tot }}$, we propose that the mobility of $\mathrm{Hg}$ in the sediment is primarily controlled by the adsorption of $\mathrm{MeHg}$ onto FeS. This could be further supported by the strong enrichment of $\mathrm{MeHg}$ in the solid phase at the SWI (Fig. 2k). The net rates obtained

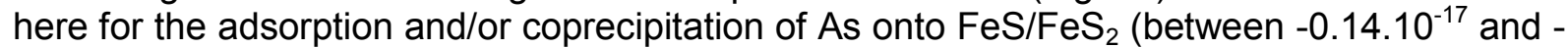
1.3.10 $\left.0^{-17} \mathrm{~mol} . \mathrm{cm}^{-3} \cdot \mathrm{s}^{-1}\right)$ and of MeHg onto FeS $\left(-2 \cdot 4 \cdot 10^{-21} \mathrm{~mol} . \mathrm{cm}^{-3} \cdot \mathrm{s}^{-1}\right)$ correspond well with those obtained, following the same method, by Couture et al. (2010) for As in Canadian lakes (between $-0.1 .10^{-17}$ and $-2.3 .10^{-17} \mathrm{~mol}^{-\mathrm{cm}^{-3}} \cdot \mathrm{s}^{-1}$ ) and by Merrit and Amirbahman (2007) for $\mathrm{Hg}_{\text {tot }}$ in the estuary of the Penobscot River (between $-7.5 .10^{-21}$ and $-14.10^{-21} \mathrm{~mol} \mathrm{~cm}^{-3} . \mathrm{s}^{-1}$ ).

\subsubsection{Cr Complexation with Dissolved Organic Matter}

The behaviour of $\mathrm{Cr}$ at site $\mathrm{V}-\mathrm{O}$ presents a particular pattern. Its high production in the porewater between -7 and $-10 \mathrm{~cm}$ (Fig. 8) cannot be explained by one of the main diagenetic reactions because this is not a depth interval where a potential carrier phase (such as 
$\mathrm{Fe}(\mathrm{OH})_{3}$ or $\left.\mathrm{MnO}_{2}\right)$ is dissolved. In contrast, the $\mathrm{Cr}$ peak in the porewater corresponds exactly to the depth of the peaks of $\mathrm{Cr}_{\mathrm{ASC}}$ (Fig. 3e) or total $\mathrm{Cr}$ (Fig. 2i) in solid phase, indicating strong control of the porewater $\mathrm{Cr}$ concentrations by the solid/liquid phase equilibrium. Finally, the thermodynamic calculations predict a strong association of $\mathrm{Cr}$ with dissolved $\mathrm{OM}$, with the presence of $\mathrm{Cr}$ complexes with humic acids $(\sim 40 \%)$ or fulvic acids $(\sim 20 \%)$. As previously shown, under anoxic conditions, $\mathrm{Cr}$ forms strong complexes with dissolved organic matter that greatly increase its mobility in porewater (e.g. Douglas et al. 1986; Beck et al., 2008). We therefore propose that the mobility of dissolved $\mathrm{Cr}$ in the absence of $\mathrm{Fe}(\mathrm{OH})_{3}$ and $\mathrm{MnO}_{2}$ in the sediments is dependent on its complexation with the dissolved $\mathrm{OM}$ in the porewater and the amount of solid phase $\mathrm{Cr}$ available.

The $\mathrm{Cr}$ profiles in the porewater at sites $\mathrm{CB}-\mathrm{A}$ and $\mathrm{CB}-\mathrm{O}$ cannot be associated with any of the previously identified main diagenetic reactions. However, in contrast with site $\mathrm{V}-\mathrm{O}$, there is no relation between the dissolved $\mathrm{Cr}$ concentrations in porewater and in particulate phase, most likely because of the lower $\mathrm{Cr}$ concentrations in the solid phase $\left(\mathrm{Cr}_{\mathrm{AsC}}\right.$ concentrations 2 and 8 times lower than at V-O; Fig. 3e) and lower DOC concentrations in the porewater (DOC concentrations 3 times lower than at $\mathrm{V}-\mathrm{O}$, Fig. 5l). At sites CB-A and CB-O, the mobility of $\mathrm{Cr}$ in the porewater is therefore expected to be very limited.

\subsection{Fluxes at the $S W I$}

The directions of the fluxes at the SWI are obtained from the concentration gradients of the dissolved species at the SWI (Table 5). When significant diffusive fluxes could be calculated by PROFILE, they are also reported.

\subsubsection{Nutrients}

Under oxic conditions at $\mathrm{V}-\mathrm{O}$, the high $\Sigma \mathrm{NO}_{3}$ production a few centimetres above the SWI (Fig. 8) due to the nitrification reaction induces a flux to the water column. However, under slightly oxic conditions (CB-O), a $\Sigma \mathrm{NO}_{3}$ flux to the sediment is predicted in relation to its consumption in the surface sediment (Table 5). These observations are consistent with the mechanisms of $\Sigma \mathrm{NO}_{3}$ consumption/production that generally result in $\Sigma \mathrm{NO}_{3}$ production from the sediment under oxic conditions and consumption in lower oxygen conditions (Deflandre et al., 2002; Belias et al., 2007, Middelburg and Levin, 2009; Emili et al., 2010). At CB-A, the absence of $\Sigma \mathrm{NO}_{3}$ reflects complete consumption of this species, as expected given the anoxic character of the site.

Under anoxic conditions (CB-A), the sediment constitutes a source of $\mathrm{NH}_{4}{ }^{+}, \Sigma \mathrm{PO}_{4}$ as well as $\Sigma \mathrm{H}_{2} \mathrm{~S}$ to the water column (Table 5), as reported in several different hypoxic/anoxic coastal systems (Belias et al. 2007; Emili et al., 2010; Mort et al., 2010). Under oxic conditions (CB-O and $\mathrm{V}-\mathrm{O}$ ), the $\Sigma \mathrm{H}_{2} \mathrm{~S}$ flux disappeared due to its complete oxidation in the first $\mathrm{cm}$ of sediment (by $\mathrm{Fe}(\mathrm{OH})_{3}, \mathrm{MnO}_{2}, \Sigma \mathrm{NO}_{3}$ and/or $\mathrm{O}_{2}$ ), but positive $\Sigma \mathrm{PO}_{4}$ and $\mathrm{NH}_{4}{ }^{+}$fluxes are also observed at $\mathrm{V}-\mathrm{O}$ in connection with the intense production of these species in the sediments (Fig. 8). However, their fluxes are much more lower than at site CB-A because of the oxidation of $\mathrm{NH}_{4}{ }^{+}(\mathrm{R} 7, \mathrm{R} 16, \mathrm{R} 19)$ and the accumulation of $\Sigma \mathrm{PO}_{4}$ in the surface sediments by adsorption onto, or coprecipitation, with $\mathrm{Fe}(\mathrm{OH})_{3}$ (R29) (Belias et al. 2007; Mort et al., 2010). At CB-O, these mechanisms eliminate the fluxes of $\Sigma \mathrm{PO}_{4}$ and $\mathrm{NH}_{4}{ }^{+}$to the water column (Table 5).

\subsubsection{Fe, Mn and trace elements}

The diffusive fluxes of trace elements at the SWI are observed to be highly dependent on the location of the diagenetic reactions inducing their remobilisation in the sediment. These reactions, previously identified are $\mathrm{Fe}(\mathrm{OH})_{3}$ dissolution for $\mathrm{As}, \mathrm{Cr}, \mathrm{Ni}$ and $\mathrm{Hg} / \mathrm{MeHg}$ and $\mathrm{MnO}_{2}$ dissolution for Co. 
The $\mathrm{Fe}(\mathrm{OH})_{3}$ reduction at the SWI at CB-A generates a positive flux of $\mathrm{Fe}$ and associated elements (As, $\mathrm{Cr}, \mathrm{Ni}, \mathrm{Hg} / \mathrm{MeHg}$, Table 5). However, only the remobilisation of As could be partially modelled by PROFILE (Fig. 7), which gives a minimum estimate of the flux as > $3.5 .10^{-17} \mathrm{~mol} . \mathrm{cm}^{-2} \cdot \mathrm{s}^{-1}$. This is several orders of magnitude lower than the As flux calculated by Chaillou et al. (2003) in the Bay of Biscay, likely due to the strong trapping of As by adsorption/coprecipitation with $\mathrm{FeS} / \mathrm{FeS}{ }_{2}$ and/or $\mathrm{Fe}(\mathrm{OH})_{3}$ in the surface sediment of Berre Lagoon.

At CB-O and $\mathrm{V}-\mathrm{O}$ (Fig. 6, Fig. 8), the presence of $\mathrm{O}_{2}$ in the water column and surface sediment leads to a deeper location of the reduction of $\mathrm{Fe}(\mathrm{OH})_{3}$ in the sediments (between -9 and $-13 \mathrm{~cm}$ and between 0 and $-4 \mathrm{~cm}$, respectively) compared with CB-A. The remobilised Fe diffusing upwards is thus mostly or completely reoxidized as $\mathrm{Fe}(\mathrm{OH})_{3}$ in the surface sediments, which severely limits or prevents its diffusion to the water column (Table 5). The high concentration of reactive $\mathrm{Fe}(\mathrm{OH})_{3}$ in surface sediments, for which $\mathrm{As}, \mathrm{Cr}$ and $\mathrm{Ni}$ have strong affinities, leads to their trapping in the surface sediments. For As and $\mathrm{Cr}$, which are at low concentrations in both the water column and the porewater $(<15 \mathrm{nM})$, no diffusive flux is identified. However for $\mathrm{Ni}$, which has concentrations in the water column significantly higher than in the porewater, a negative flux is induced (Table 5). This observation is in contrast with common observations in coastal areas (Westerlund et al. 1986; Ciceri et al. 1992; Cheevaporn et al. 1995; Warnken et al. 2001; Santos-Echeandia et al., 2009), where exports of $\mathrm{Ni}$ from the sediment to the water column are generally reported. This is likely due to the high immobilisation efficiency of $\mathrm{Ni}$ by $\mathrm{Fe}(\mathrm{OH})_{3}$ and as NiS into the Berre Lagoon sediments.

The results for $\mathrm{Cr}$ at site $\mathrm{V}-\mathrm{O}$ are peculiar. Despite the strong presence of $\mathrm{Fe}(\mathrm{OH})_{3}$ in the surface sediments, the high levels of dissolved organic ligands most likely explain the observed $\mathrm{Cr}$ release into the water column (Table 5) by promoting the mobility of $\mathrm{Cr}$ in the porewater and limiting its adsorption onto $\mathrm{Fe}(\mathrm{OH})_{3}$. This flux is in the range of those reported for other aquatic environments (Cheevaporn et al., 1995, Blasco et al., 2000). The primary source of $\mathrm{Cr}$ in the sediment is the highly enriched particulate phase at $-10 \mathrm{~cm}$ (Fig. 2i), which corresponds to the $\mathrm{Cr}$ released into the lagoon in the 1960-1970s (Rigaud et al., 2011). Although over time this stock will gradually be buried, under similar conditions, the flux of $\mathrm{Cr}$ to the water column would most likely continues for several decades.

The $\mathrm{MnO}_{2}$ reduction in surface sediments induces an $\mathrm{Mn}$ flux to the water column at the three sites (Table 5). However, these fluxes are very different, as the flux at CB-O is almost 100 times greater than at CB-A (not quantifiable at $\mathrm{V}-\mathrm{O}$ ). This difference is directly associated with the significantly higher $\mathrm{MnO}_{2}$ reduction rate at $\mathrm{CB}-\mathrm{O}$ in comparison with $\mathrm{CB}-$ A (approximately 70 times). At $\mathrm{CB}-\mathrm{O}, 70 \%$ of the produced $\mathrm{Mn}$ is exported to the water column, versus $46 \%$ at $C B-A$.

At $\mathrm{CB}-\mathrm{O}$ and $\mathrm{V}-\mathrm{O}$, positive fluxes of $\mathrm{Co}$ are observed in relation to its remobilisation during the $\mathrm{MnO}_{2}$ dissolution (Table 5). The flux quantified at CB-O is in the range of those reported for Co in other coastal environments (Ciceri et al. 1992; Point et al. 2007; Santos-Echeandia et al., 2009) and results in the export of $60 \%$ of the Co remobilised under the SWI at CB-O. Under anoxic conditions (CB-A), despite the $\mathrm{MnO}_{2}$ reduction at the SWI, the flux of Co occurs from the water column to the sediments (Table 5) due to the precipitation of CoS at the SWI.

The comparison of the calculated diffusive fluxes for those elements diffusing to the water column ( $\mathrm{Cr}$ at V-O; As at $\mathrm{CB}-\mathrm{A}$ and $\mathrm{Co}$ at $\mathrm{CB}-\mathrm{O}$ ) with the accumulation rate of the trace elements deposited on the sediments (estimated from the trace element concentrations in the surface sediments, the sedimentation rate and the wet density of the surface sediments), indicates highly efficient trapping of $\mathrm{Cr}$ at $\mathrm{V}-\mathrm{O}$ sediments $(<1 \%$ of the deposited amount diffusing to the water column), but a significant amount (between 10 and 30\%) of As (CB-A) and $\mathrm{Co}(\mathrm{CB}-\mathrm{O})$ can be released to the water column following deposition. 
In summary, the occurrence and intensity of the fluxes of trace elements to the water column are directly enhanced when their remobilisation reactions occur close to the SWI, and this situation is favoured under hypoxic/anoxic conditions.

\subsection{Evaluation of the influence of the water column reoxygenation in the central basin}

The anoxic conditions in the bottom water of the Central Basin of the Berre lagoon (Fig. 1) were quasi-perennial before 2000, largely dominant until 2005 and occurred approximately $35 \%$ of the time in 2009 (EDF, pers. com.). Anoxia has declined gradually with the establishment of regulations on the freshwater release from the hydroelectric power plant. In the future, it is possible that new regulations will continue to limit or stop these releases, inducing a partial or complete destratification of the water column and a probable increase of benthic water oxygen contents.

Our work enables to identify the main processes controlling trace element mobility in Berre lagoon sediments. The strong influence of the oxygen concentrations in the water column on both the intensity and direction of the fluxes at the SWI have been discussed. If we now consider the differences observed at site $C B$ during anoxic conditions (CB-A) and oxic conditions (CB-O, $\mathrm{O}_{2}=38 \% \mathrm{O}_{2}$ saturation), it is possible to predict the influence of the reoxygenation of the water column in the central basin on the fluxes of nutrients and trace elements.

The three main species controlling the mobility of trace elements in the sediment of the Central Basin are $\Sigma \mathrm{H}_{2} \mathrm{~S}, \mathrm{Fe}$ and $\mathrm{Mn}$. Their evolution as conditions change from anoxic to oxic is thus particularly important to predict the evolution of the fluxes of trace elements. Under oxic conditions, these species are primarily oxidized in surface sediments causing 1) the precipitation of $\mathrm{Fe}(\mathrm{OH})_{3}$ and $\mathrm{MnO}_{2}$ at the SWI and the burial of their reduction zone and 2) the deepening of the occurrence of $\Sigma \mathrm{H}_{2} \mathrm{~S}$ in the sediment and thus the depth where sulphides can be involved in the immobilisation of trace elements.

An $\mathrm{O}_{2}$ saturation of $38 \%$ in the water column (CB-O) seems to be sufficient to eliminate the upward flux of dissolved $\mathrm{Fe}$ from the sediment and to promote complete $\mathrm{Fe}(\mathrm{OH})_{3}$ precipitation in the surface sediments. Therefore, we propose that reoxygenation of the water column $\geq 40 \%$ of $\mathrm{O}_{2}$ saturation will induce a reduction or an elimination of the upward fluxes of all of the species associated with the Fe cycle (As, $\mathrm{Cr}, \mathrm{Ni}, \mathrm{Hg} / \mathrm{MeHg}$ and $\Sigma \mathrm{PO}_{4}$ ) by their readsorption onto or, co-precipitation with, $\mathrm{Fe}(\mathrm{OH})_{3}$ in the surface sediments. However, for $\mathrm{Hg}$ and $\mathrm{MeHg}$, which were not measured under oxic conditions, the changes in their fluxes at the SWI under well oxygenated overlying water are more hypothetical and will largely depend on the competition between the kinetics of adsorption onto $\mathrm{Fe}(\mathrm{OH})_{3}$ and the kinetics of remobilisation and/or methylation in the surface sediments.

Results for $\mathrm{Mn}$ are different with a calculated flux calculated higher in an oxygenated water column (38\% $\mathrm{O}_{2}$ saturation) than under anoxic conditions (Table 5). This difference may be attributed to the contrasted diagenetic behaviour of these two redox species: the $\mathrm{MnO}_{2}$ reduction occurs for less reduced conditions than for $\mathrm{Fe}(\mathrm{OH})_{3}$, and the oxidation kinetic of $\mathrm{Fe}$ is faster than that of $\mathrm{Mn}$, which also requires microbial mediation (Burdige, 1993). The consequence is that an incomplete oxygenation $\left(\leq 40 \% \mathrm{O}_{2}\right.$ saturation) in the central basin will result in an intense $\mathrm{MnO}_{2}$ reduction in the surface sediments and therefore a potential higher release of $\mathrm{Co}$ to the water column, in comparison with anoxic conditions. However, we can suppose that complete oxidation of $\mathrm{Mn}$ in the surface sediments may occur under complete oxygenation and may eliminate the flux of $\mathrm{Mn}$ and Co to the water column.

Water column oxygenation of $38 \% \mathrm{O}_{2}$ saturation results in the oxidation of $\mathrm{NH}_{4}{ }^{+}$and the decrease or elimination of its flux from the sediments at site CB (Table 5). However, it also results in the formation of $\Sigma \mathrm{NO}_{3}$ in the water column under high oxygen concentrations, as observed at $\mathrm{V}-\mathrm{O}$ (Fig. 8), which can contribute to the eutrophication of the system. 
All of these predictions are based only on the biogeochemical processes studied in this work. This does not consider the influence of sediments recolonisation by macrobenthic organisms that is expected upon complete reoxygenation of the bottom water. In such case, the bioturbation processes would significantly disturb the locations of the main diagenetic reactions in the surface sediments and thus the fluxes of the trace elements and nutrients, as evidenced by the relative complexity of their profiles at V-O (Morse and Eldridge, 2007; Middelburg and Levin, 2009). Consequently, predictions previously made are thus valid in the case of a likely scenario of decrease but persistence of anoxic events in the Central Basin that will prevent sediment recolonization by macrofauna.

\section{Conclusion}

Coupling multiple methodological approaches (microelectrodes, peepers, sediment cores, chemical extractions, thermodynamic calculations and steady-state transport-reaction modelling) in a Mediterranean lagoon exhibiting both contaminated sediments and contrasting oxygen concentrations in the overlying water allowed for the identification of processes that control the mobility and fluxes of trace elements (As, Co, $\mathrm{Cr}, \mathrm{Ni}, \mathrm{Hg}, \mathrm{MeHg}$ ) and nutrients $\left(\Sigma \mathrm{NO}_{3}, \mathrm{NH}_{4}{ }^{+}, \Sigma \mathrm{PO}_{4}\right)$ in the sediment under different oxygen contents in the water column.

The main diagenetic reactions identified in the control of the mobility and fluxes of trace elements in sediments are the adsorption onto, or co-precipitation with, Fe oxy-hydroxides (As, $\mathrm{Cr}, \mathrm{Ni}, \mathrm{Hg} / \mathrm{MeHg}$ ), Mn oxy-hydroxydes (Co) and $\mathrm{FeS} / \mathrm{FeS}{ }_{2}$ (As, MeHg) or the direct precipitation as metal sulphides ( $\mathrm{Co}, \mathrm{Ni})$. The remobilisation of trace elements occurs principally when $\mathrm{Fe}$ and $\mathrm{Mn}$ oxy-hydroxydes are reduced, but such remobilisation can be partially or totally prevented in the presence of sulphide depending on the kinetic competitions. The fluxes of trace elements to the overlying water are then essentially dependent on the location of these remobilisation reactions in the sediment column, which were shown to be primarily dependent on the oxygenation of the water column.

Under anoxic conditions in the overlying water, reduction of $\mathrm{Fe}$ and $\mathrm{Mn}$ oxy-hydroxydes and $\mathrm{SO}_{4}{ }^{2-}$ (and thus $\Sigma \mathrm{H}_{2} \mathrm{~S}$ production) occurs directly at the SWI. This leads to a kinetic competition between remobilisation and trapping reactions at the SWI. This resulted in the diffusion of $\mathrm{Fe}, \mathrm{Mn}, \mathrm{Cr}, \mathrm{Ni}, \mathrm{As}$ and $\mathrm{Hg} / \mathrm{MeHg}$ as well as $\Sigma \mathrm{H}_{2} \mathrm{~S}, \mathrm{NH}_{4}{ }^{+}$and $\Sigma \mathrm{PO}_{4}$ to the water column. However for $\mathrm{Co}$, the precipitation as CoS at the SWI dominates the Co remobilisation during $\mathrm{Mn}$ oxy-hydroxydes reduction, preventing its diffusion to the overlying water. At the same site under oxic conditions, the deepening of depth interval where Fe oxyhydroxides are reduced in the sediment induces a decrease or elimination of the upward fluxes of associated trace elements to the water column. However, the disappearance of $\Sigma \mathrm{H}_{2} \mathrm{~S}$ in surface sediment prevents the immobilisation of Co (associated with $\mathrm{Mn}$ and not $\mathrm{Fe}$ ) and leads, in this case, to an increase in its flux to the overlying water column. At the site exhibiting perennial oxic conditions in water column, the sediments are a source of $\Sigma \mathrm{NO}_{3}, \mathrm{Fe}$, $\mathrm{Mn}$, Co and $\mathrm{Cr}$ and to a lesser extent of $\Sigma \mathrm{PO}_{4}$ and $\mathrm{NH}_{4}{ }^{+}$, but still are a sink for $\mathrm{Ni}$. The behaviour of $\mathrm{Cr}$ in the sulphidic sediment is peculiar because its remobilisation has been observed to be decoupled from the main diagenetic reactions and primarily controlled by its complexation with dissolved organic matter in the porewater.

A potential future reoxygenation of the water column in the central basin of the Berre Lagoon will likely decrease or eliminate the release of trace elements and $\Sigma \mathrm{H}_{2} \mathrm{~S}, \mathrm{NH}_{4}{ }^{+}$and $\Sigma \mathrm{PO}_{4}$ to the water column. However, if the oxygenation of the water column is not complete, the fluxes of $\mathrm{Mn}$ and Co will likely be much higher than those prevailing under the current anoxic 
conditions. Finally, the improvement of oxygenation of the water column will likely increase the fluxes of $\mathrm{\Sigma NO}_{3}$.

\section{Acknowledgements}

We acknowledge The Région Provence-Alpes-Côtes-d'Azur and the GIPREB (Groupement d'Intérêt Public pour la Réhabilitation de l'Etang de Berre) for the PhD grant of Sylvain Rigaud. We thank Dominique Poirier for analytic assistance. Financial supports were provided by the French INSU-EC2CO programs: BERTOX project to Olivier Radakovitch and BIOMIN project to Bruno Deflandre.

\section{References}

Abi-Ghanem, C., Nakhlé, K., Khalaf, G., Cossa, D., 2011. Mercury distribution and methylmercury mobility in the sediments of three sites on the Lebanese Coast, Eastern Mediterranean. Arch. Environ. Contam. Toxicol. 60, 394-405.

Anderson, L., 1979. Simultaneous spectrophotometric determination of nitrite and nitrate by flow injection analysis. Anal. Chim. Acta 110, 123-128.

Anschutz, P., Sundby, B.r., Lefrancois, L., Luther lii, G.W., Mucci, A., 2000. Interactions between metal oxides and species of nitrogen and iodine in bioturbated marine sediments. Geochim. Cosmochim. Acta 64, 2751-2763.

Beck, M., Dellwig, O., Schnetger, B., Brumsack, H.-J.r., 2008. Cycling of trace metals (Mn, Fe, Mo, U, $\mathrm{V}, \mathrm{Cr}$ ) in deep pore waters of intertidal flat sediments. Geochim. Cosmochim. Acta 72, 28222840.

Belias, C., Dassenakis, M., Scoullos, M., 2007. Study of the N, P and Si fluxes between fish farm sediment and seawater. Results of simulation experiments employing a benthic chamber under various redox conditions. Mar. Chem. 103, 266-275.

Berg, P., Rysgaard-Petersen, N., Rysgaard, S., 1998. Interpretation of measured concentration profiles in sediment pore water. Limnol. Oceanogr. 43, 1500-1510.

Boudreau, B.P., 1997. Diagenetic models and their implementation: modelling transport and reactions in aquatic sediments. Berlin.

Buffle, J., 1988. Complexation Reactions in Aquatic Systems: Analytical Approach. Chichester.

Burdige, D.J., 1993. The biogeochemistry of manganese and iron reduction in marine sediments. Earth-Sci. Rev. 35, 249-284.

Canavan, R.W., Slomp, C.P., Jourabchi, P., Van Cappellen, P., Laverman, A.M., van den Berg, G.A., 2006. Organic matter mineralization in sediment of a coastal freshwater lake and response to salinization. Geochim. Cosmochim. Acta 70, 2836-2855.

Canavan, R.W., Van Cappellen, P., Zwolsman, J.J.G., van den Berg, G.A., Slomp, C.P., 2007. Geochemistry of trace metals in a fresh water sediment: Field results and diagenetic modeling. Sci. Total Environ. 381, 263-279.

Chaillou, G., Schäfer, J., Anschutz, P., Lavaux, G., Blanc, G., 2003. The behaviour of arsenic in muddy sediments of the Bay of Biscay (France). Geochim. Cosmochim. Acta 67, 2993-3003.

Cheevaporn, V., Jacinto, G.S., San Diego-McGlone, M.L., 1995. Heavy metal fluxes in Bang Pakong River Estuary, Thailand: Sedimentary vs diffusive fluxes. Mar. Pollut. Bull. 31, 290-294.

Ciceri, G., Maran, C., Martinotti, W., Queirazza, G., 1992. Geochemical cycling of heavy metals in a marine coastal area: benthic flux determination from pore water profiles and in situ measurements using benthic chambers. Hydrobiologia 235-236, 501-517.

Couture, R.-M., Gobeil, C., Tessier, A., 2010. Arsenic, iron and sulfur co-diagenesis in lake sediments. Geochim. Cosmochim. Acta 74, 1238-1255.

Deflandre, B., Duchêne, J.-C., 2010. PRO2FLUX - A software program for profile quantification and diffusive O2 flux calculations. Environ. Model. Software 25, 1059-1061.

Deflandre, B., Mucci, A., Gagné, J.-P., Guignard, C., Sundby, B., 2002. Early diagenetic processes in coastal marine sediments disturbed by a catastrophic sedimentation event. Geochim. Cosmochim. Acta 66, 2547-2558.

Diaz, R.J., Rosenberg, R., 2008. Spreading Dead Zones and Consequences for Marine Ecosystems. Science 321, 926-929.

Douglas, G.S., Mills, G.L., Quinn, J.G., 1986. Organic copper and chromium complexes in the interstitial waters of Narragansett Bay sediments. Mar. Chem. 19, 161-174. 
Emili, A., Koron, N., Covelli, S., Faganeli, J., Acquavita, A., Predonzani, S., Vittor, C.D., 2011. Does anoxia affect mercury cycling at the sediment-water interface in the Gulf of Trieste (northern Adriatic Sea)? Incubation experiments using benthic flux chambers. Appl. Geochem. 26, 194204.

Etcheber, H., Relexans, J.-C., Beliard, M., Weber, O., Buscail, R., Heussner, S., 1999. Distribution and quality of sedimentary organic matter on the Aquitanian margin (Bay of Biscay). Deep Sea Research Part II 46, 2249-2288.

Froelich, P.N., Klinkhammer, G.P., Bender, M.L., Luedtke, N.A., Heath, G.R., Cullen, D., Dauphin, P., Hammond, D., Hartman, B., Maynard, V., 1979. Early oxidation of organic matter in pelagic sediments of the eastern equatorial Atlantic: suboxic diagenesis. Geochim. Cosmochim. Acta 43, 1075-1090.

Gallon, C., Tessier, A., Gobeil, C., Alfaro-De La Torre, M.C., 2004. Modeling diagenesis of lead in sediments of a Canadian Shield lake. Geochim. Cosmochim. Acta 68, 3531-3545.

Hollweg, T.A., Gilmour, C.C., Mason, R.P., 2009. Methylmercury production in sediments of Chesapeake Bay and the mid-Atlantic continental margin. Mar. Chem. 114, 86-101.

Huerta-Diaz, M.A., Tessier, A., Carignan, R., 1998. Geochemistry of trace metals associated with reduced sulfur in freshwater sediments. Appl. Geochem. 13, 213-233.

Hulth, S., Aller, R.C., Gilbert, F., 1999. Coupled anoxic nitrification/manganese reduction in marine sediments. Geochim. Cosmochim. Acta 63, 49-66.

Kostka, J.E., Luther lii, G.W., 1994. Partitioning and speciation of solid phase iron in saltmarsh sediments. Geochim. Cosmochim. Acta 58, 1701-1710.

Luoma, S.N., Rainbow, P.S., 2008. Metal contamination in aquatic environment. Science and lateral management. Cambridge.

Malcolm, R., 1985. Geochemistry of Stream Fulvic and Humic Substances. In: Sons, J.W.a. (Ed.), Humic Substances in Soil, Sediment, and Water: Geochemistry, Isolation, and Characterization. New York, pp. 181-209.

Merritt, K.A., Amirbahman, A., 2007. Mercury dynamics in sulfide-rich sediments: Geochemical influence on contaminant mobilization within the Penobscot River estuary, Maine, USA. Geochim. Cosmochim. Acta 71, 929-941.

Metzger, E., Simonucci, C., Viollier, E., Sarazin, G., Prévot, F., Jézéquel, D., 2007. Benthic response to shellfish farming in Thau lagoon: Pore water signature. Estuar. Coast. Shelf Sci. 72, 406419.

Middelburg, J.J., Levin, L.A., 2009. Coastal hypoxia and sediment biogeochemistry. Biogeosciences 6 , 1273-1293.

Morse, J.W., Eldridge, P.M., 2007. A non-steady state diagenetic model for changes in sediment biogeochemistry in response to seasonally hypoxic/anoxic conditions in the "dead zone" of the Louisiana shelf. Mar. Chem. 106, 239-255.

Morse, J.W., Luther lii, G.W., 1999. Chemical influences on trace metal-sulfide interactions in anoxic sediments. Geochim. Cosmochim. Acta 63, 3373-3378.

Mort, H.P., Slomp, C.P., Gustafsson, B.G., Andersen, T.r.J., 2010. Phosphorus recycling and burial in Baltic Sea sediments with contrasting redox conditions. Geochim. Cosmochim. Acta 74, 13501362.

Mucci, A., Richard, L.-F., Lucotte, M., Guignard, C., 2000. The Differential Geochemical Behavior of Arsenic and Phosphorus in the Water Column and Sediments of the Saguenay Fjord Estuary, Canada. Aquatic Geochemistry 6, 293-324.

Parkhurst, D.L., Appelo, C.A.J., 1999. User Guide to PHREEQC (Version 2) : A computer program for speciation, batch-reaction, one-dimensional transport, and inverse geochemical calculations. In: Investigations, U.S.G.S.W.-R. (Ed.), pp. 312.

Pingitore, N.E., Eastman, M.P., Sandidge, M., Oden, K., Freiha, B., 1988. The coprecipitation of manganese(II) with calcite: an experimental study. Mar. Chem. 25, 107-120.

Point, D., Monperrus, M., Tessier, E., Amouroux, D., Chauvaud, L., Thouzeau, G., Jean, F., Amice, E., Grall, J., Leynaert, A., Clavier, J., Donard, O.F.X., 2007. Biological control of trace metal and organometal benthic fluxes in a eutrophic lagoon (Thau Lagoon, Mediterranean Sea, France). Estuar. Coast. Shelf Sci. 72, 457-471.

Rickard, D., Morse, J.W., 2005. Acid volatile sulfide (AVS). Mar. Chem. 97, 141-197.

Riedel, G.F., Sanders, J.G., Osman, R.W., 1997. Biogeochemical Control on the Flux of Trace Elements from Estuarine Sediments: Water Column Oxygen Concentrations and Benthic Infauna. Estuar. Coast. Shelf Sci. 44, 23-38.

Rigaud, S., Radakovitch, O., Nerini, D., Picon, P., Garnier, J.M., 2011. Reconstructing historical trends of Berre lagoon contamination from surface sediment datasets: Influences of industrial regulations and anthropogenic silt inputs. J. Environ. Manage. 92, 2201-2210.

Santos-Echeandia, J., Prego, R., Cobelo-Garcla, A., Millward, G.E., 2009. Porewater geochemistry in 
a Galician Ria (NW Iberian Peninsula): Implications for benthic fluxes of dissolved trace elements (Co, $\mathrm{Cu}, \mathrm{Ni}, \mathrm{Pb}, \mathrm{V}, \mathrm{Zn}$ ). Mar. Chem. 117, 77-87.

Schulz, H.D., 2006. Quantification of early diagenesis: dissolved constituents in pore water and signals in the solid phase. In: Schulz, H.D., Zabel, M. (Eds.), Marine geochemistry. Springer, Berlin, pp. 582.

Stockdale, A., Davison, W., Zhang, H., Hamilton-Taylor, J., 2010. The Association of Cobalt with Iron and Manganese (Oxyhydr)oxides in Marine Sediment. Aquatic Geochemistry 16, 575-585.

Sundby, B., Anderson, L.G., Hall, P.O.J., Iverfeldt, A., Rutgers van der Loeff, M.M., Westerlund, S.F.G., 1986. The effect of oxygen on release and uptake of cobalt, manganese, iron and phosphate at the sediment-water interface. Geochim. Cosmochim. Acta 50, 1281-1288.

Tipping, E., 1998. Humic lon-Binding Model VI: An Improved Description of the Interactions of Protons and Metal lons with Humic Substances. Aquatic Geochemistry 4, 3-47.

Tseng, C., de Diego, A., Pinaly, H., Amouroux, D., OFX, D., 1998. Cryofocusing coupled to atomic adsorption spectrometry for rapid and simple mercury speciation in environmental matrices. Journal of analytical atomic spectrometry $13,755-764$.

Wang, Y., Van Cappellen, P., 1996. A multicomponent reactive transport model of early diagenesis: Application to redox cycling in coastal marine sediments. Geochim. Cosmochim. Acta 60, 2993-3014.

Warnken, K.W., Gill, G.A., Griffin, L.L., Santschi, P.H., 2001. Sediment-water exchange of Mn, Fe, Ni and $\mathrm{Zn}$ in Galveston Bay, Texas. Mar. Chem. 73, 215-231.

Westerlund, S.F.G., Anderson, L.G., Hall, P.O.J., Iverfeldt, k., Van Der Loeff, M.M.R., Sundby, B.r., 1986. Benthic fluxes of cadmium, copper, nickel, zinc and lead in the coastal environment. Geochim. Cosmochim. Acta 50, 1289-1296.

\section{Tables}

Table 1: Location and characteristic of sampling sites. The physicochemical parameters reported correspond to the deepest (about $10-20 \mathrm{~cm}$ above the SWI) measure carried out for each site in the water column.

\begin{tabular}{lccc}
\hline & CB-A & CB-O & V-O \\
\hline Location & $05^{\circ} 05.845 \mathrm{E} / 43^{\circ} 26.529 \mathrm{~N}$ & $5^{\circ} 12.166 \mathrm{E} / 43^{\circ} 28.032 \mathrm{~N}$ \\
Water column depth $(\mathrm{m})$ & \multicolumn{2}{c}{9.0} & 4.5 \\
Sedimentation rate $\left(\mathrm{cm} \cdot \mathrm{a}^{-1}\right)^{\mathrm{a}}$ & \multicolumn{2}{c}{0.28} & 0.34 \\
\hline Temperature $\left({ }^{\circ} \mathrm{C}\right)$ & 21 & 18 & 21 \\
Salinity & 35.5 & 32.6 & 20.8 \\
$\mathrm{pH}$ & 7.45 & 7.65 & 7.35 \\
$\mathrm{O}_{2}\left(\mathrm{mg} . \mathrm{L}^{-1}\right) /(\%$ saturation $)$ & $<0.2 /<3$ & $2.9 / 38$ & $4.6 / 60$ \\
Eh $(\mathrm{mV} / \mathrm{NHE})$ & 40 & 330 & 380 \\
\hline
\end{tabular}

(a) from Salençon, Pers. Com..

Table 2: Average concentrations of $\mathrm{Fe}_{\mathrm{ASC}}$ and $\mathrm{Mn}_{\mathrm{ASC}}$ reactive minerals (as $\mu \mathrm{g}$ of $\mathrm{Fe}$ or $\mathrm{Mn}$ per $\mathrm{g}$ of sediment or $\%$ of total $\mathrm{Fe}$ or $\mathrm{Mn}$ ) in sediments over the depth interval identified using ascorbate extractions.

\begin{tabular}{|c|c|c|c|c|c|c|c|c|c|}
\hline \multirow[b]{2}{*}{$\begin{array}{l}\text { Reactive } \\
\text { minerals }\end{array}$} & \multicolumn{3}{|c|}{ CB-A } & \multicolumn{3}{|c|}{ CB-O } & \multicolumn{3}{|c|}{ V-O } \\
\hline & $\begin{array}{c}\text { Depth } \\
\text { interval } \\
(\mathrm{cm})\end{array}$ & $\begin{array}{c}\mathrm{C} \\
\left(\mu \mathrm{gg} \cdot \mathrm{g}^{-}\right. \\
\mathrm{C}\end{array}$ & $\%_{\text {tot }}$ & $\begin{array}{l}\text { Depth } \\
\text { interval } \\
(\mathrm{cm})\end{array}$ & $\begin{array}{c}\mathrm{C} \\
\left(\mu \mathrm{g} \cdot \mathrm{g}^{-}\right. \\
\mathrm{l}\end{array}$ & $\%_{\text {tot }}$ & $\begin{array}{c}\text { Depth } \\
\text { interval } \\
(\mathrm{cm})\end{array}$ & $\begin{array}{c}\mathrm{C} \\
\left(\mu \mathrm{gg} \cdot \mathrm{g}^{-}\right. \\
\mathrm{T}\end{array}$ & $\%_{\text {tot }}$ \\
\hline $\mathrm{Fe}_{\mathrm{ASC}}$ & $0-3$ & 1960 & 9. & $0-3$ & 2110 & 11. & $0-3$ & 5230 & 23.9 \\
\hline $\mathrm{Mn}_{\mathrm{ASC}}$ & $0-2$ & 19.4 & 5.5 & $0-2$ & 9.5 & 2.7 & $0-3$ & 83.3 & 21.9 \\
\hline
\end{tabular}


Table 3: Main diagenetic reactions and reactions involving trace elements. $\mathrm{Me}^{2+}, \mathrm{Fe}(\mathrm{OH})_{3}$ and $\mathrm{MnO}_{2}$ represent the trace elements, the Fe and $\mathrm{Mn}$ oxy-hydroxides respectively. $\mathrm{Me}-\mathrm{Fe}(\mathrm{OH})_{3}, \mathrm{Me}-\mathrm{MnO}_{2}, \mathrm{Me}-\mathrm{FeS}, \mathrm{MeFeS}$ and Me-OM represent trace elements association on particulate phases by adsorption or coprecipitation without specifying the nature. 1) Wang and Van Cappellen, 1996 ; 2) Canavan et al., 2006 ; 3) Anschutz et al., 2000 ; 4) Hulth, 1999 ; 5) Boudreau, 1997.

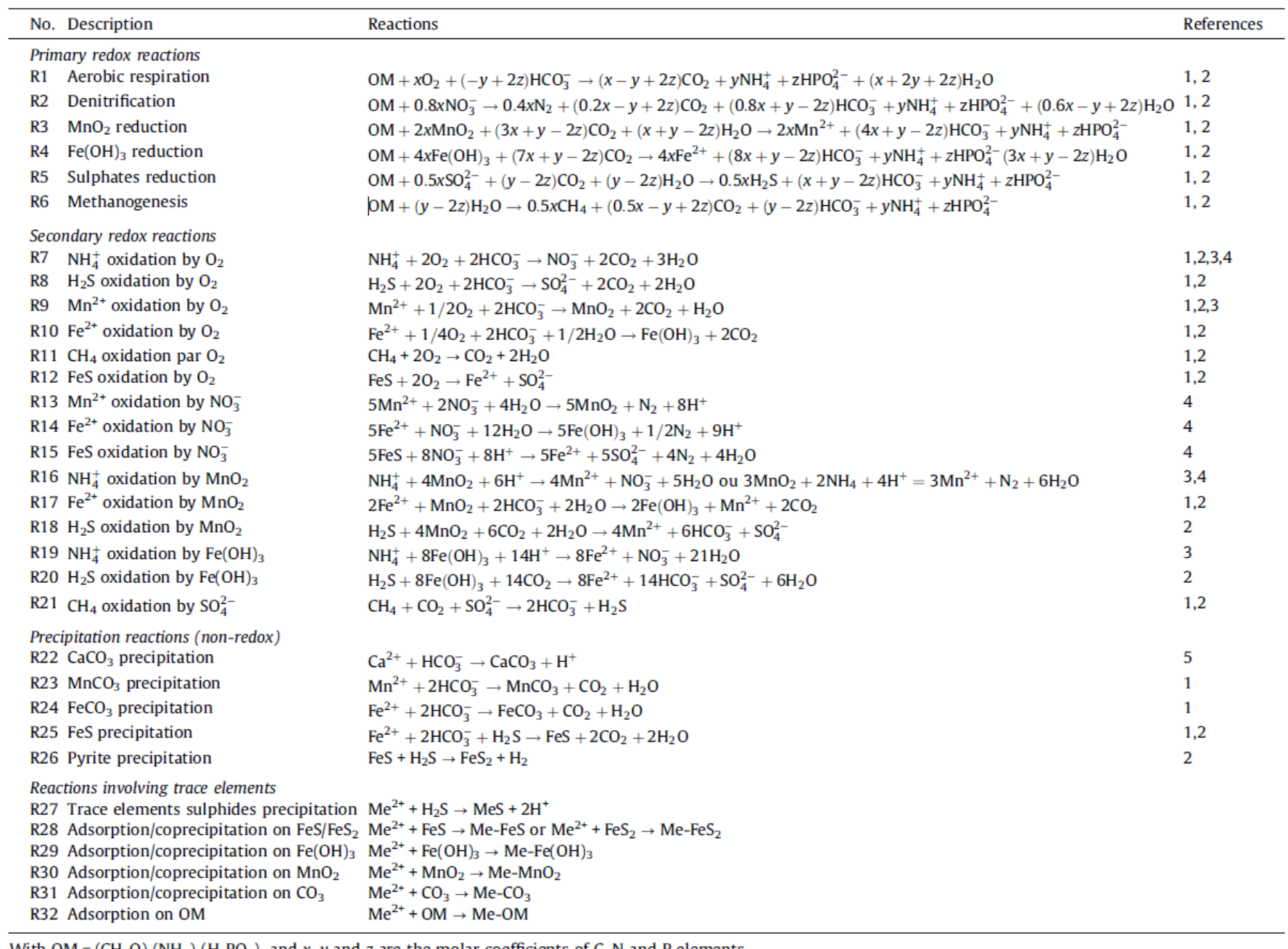


Table 4: Main diagenetic reactions and their depth intervals

\begin{tabular}{lccc}
\hline & \multicolumn{3}{c}{ Depth intervals $(\mathrm{cm})$} \\
Main diagenetic reactions & CB-O & CB-A & V-O \\
\hline $\mathrm{O}_{2}$ consumption & $0 /-0.045$ & no & $0 /-0.19$ \\
Denitrification & $0 /-5.7$ & no & $+5.0 /-2$ \\
$\mathrm{MnO}_{2}$ reduction & $0 /-2.4$ & $0 /-3.7$ & $+1 /+3 ;-5.1 /-7.6$ \\
$\mathrm{Fe}(\mathrm{OH})_{3}$ reduction & $-9.5 /-11.9$ & $+1 / 0$ & $0 /-4.2 ;-6.3 /-8.4$ \\
$\mathrm{SO}_{4}{ }^{2-}$ reduction & $-14.3 /-28.6$ & $0 /-5.0$ & $-6.6 /-26.2$ \\
$\mathrm{FeS} / \mathrm{FeS}_{2}$ precipitation & $-11.9 /-28.6$ & $0 /-2.0$ & $(-3 ?)-5.9 /-10.6$ \\
Carbonate precipitation & $-10 /-28.6$ & $-2 /-30$ & $-10 /-26.2$ \\
\hline
\end{tabular}

Table 5: Synthesis of fluxes at the SWI in sites CB-O, CB-A and V-O. The arrows represent the direction of the fluxes. When significant, the diffusive fluxes $\left(\mathrm{mol}^{\mathrm{cm}} \mathrm{cm}^{-2} . \mathrm{s}^{-1}\right)$, quantified from the concentration gradients modeled below the SWI by PROFILE are reported. A negative value indicates a flux from the overlying water to the sediment, a positive value indicates a flux from the sediment to the overlying water.

\begin{tabular}{lccc}
\hline & CB-O & CB-A & V-O \\
\hline $\mathrm{O}_{2}$ & $\Downarrow\left(-8.7 .10^{-11}\right)$ & & $\Downarrow\left(-3.2 .10^{-11}\right)$ \\
$\mathrm{NO}_{3}{ }^{-}$ & $\Downarrow\left(-1.89 .10^{-14}\right)$ & & $\Uparrow$ \\
$\sum \mathrm{NH}_{4}{ }^{+}$ & $\sim 0$ & $\Uparrow\left(6.9 .10^{-13}\right)$ & $\Uparrow\left(6.2 .10^{-13}\right)$ \\
$\sum \mathrm{PO}_{4}$ & $\sim 0$ & $\Uparrow\left(2.3 .10^{-14}\right)$ & $\Uparrow\left(0.1 .10^{-14}\right)$ \\
$\sum \mathrm{H}_{2} \mathrm{~S}$ & $\sim 0$ & $\Uparrow\left(4.5 .10^{-13}\right)$ & 0 \\
$\mathrm{Fe}$ & $\sim 0$ & $\Uparrow$ & $\Uparrow\left(0.56 .10^{-14}\right)$ \\
$\mathrm{Mn}$ & $\Uparrow\left(1.17 .10^{-13}\right)$ & $\Uparrow\left(0.02 .10^{-13}\right)$ & $\Uparrow$ \\
$\mathrm{As}$ & $\sim 0$ & $\Uparrow\left(>3.5 .10^{-17}\right)$ & $\sim 0$ \\
$\mathrm{Co}$ & $\Uparrow\left(8.20 .10^{-17}\right)$ & $\Downarrow\left(-0.41 .10^{-17}\right)$ & $\Uparrow$ \\
$\mathrm{Cr}$ & $\sim 0$ & $\Uparrow$ & $\Uparrow\left(1.1 .10^{-17}\right)$ \\
$\mathrm{Ni}$ & $\Downarrow\left(-8.7 .10^{-18}\right)$ & $\Uparrow$ & $\Downarrow\left(-1.7 .10^{-18}\right)$ \\
$\mathrm{Hg}$ & n.d. & $\Uparrow$ & n.d. \\
$\mathrm{MeHg}$ & n.d. & $\Uparrow$ & n.d. \\
\hline
\end{tabular}


Figure 1: Study area and sampling sites. The area of the Central Basin subject to anoxic events and presenting no macrobenthic organism, is reported.

Figure 2: Total concentration profiles of (a-f) selected majors constituents (TOC, $\mathrm{N}_{\text {tot }}, \mathrm{TIC}, \mathrm{Fe}$, $\mathrm{Mn}$ and $\mathrm{S}$ ) and (g-l) trace elements (As, $\mathrm{Co}, \mathrm{Cr}, \mathrm{Hg}, \mathrm{MeHg}$ and $\mathrm{Ni}$ ) in sediment cores from sites CB-A, CB-O and V-O. When available, the natural geochemical background (NGB, mean \pm 1 standard deviation) for trace elements for the area obtained from the deepest part of long sediment cores (Rigaud et al., 2011) is reported.

Figure 3: Profile of $\mathrm{Fe}, \mathrm{Mn}, \mathrm{As}, \mathrm{Co}, \mathrm{Cr}$ and $\mathrm{Ni}$ concentrations extracted by ascorbate in CB-A, $\mathrm{CB}-\mathrm{O}$ and $\mathrm{V}-\mathrm{O}$ sediments cores.

Figure 4: Oxygen profiles obtained by ex-situ microelectrodes measurements with overlying water oxygenation adjusted to in-situ conditions. The horizontal dashed line represents the sediment/water interface.

Figure 5: Concentration profiles of major species (a-l) and trace elements (m-r) in pore and overlying waters from peepers on sites $\mathrm{CB}-\mathrm{A}, \mathrm{CB}-\mathrm{O}$ and $\mathrm{V}-\mathrm{O}$ obtained by peepers. The horizontal dashed line represents the sediment/water interface.

Figure 6: A) concentration profiles of $\Sigma \mathrm{NO}_{3}, \mathrm{Mn}, \mathrm{Fe}, \mathrm{SO}_{4}{ }^{2-}, \Sigma \mathrm{H}_{2} \mathrm{~S}, \mathrm{Co}, \mathrm{Cr}$ and $\mathrm{Ni}$ obtained by peeper in the site CB-O. The fit of experimental values, areas and net rates of reactions obtained using PROFILE are also reported. B) Schematic representation of areas and depth integrated rates of production/consumption reactions of dissolved species in porewaters obtained by PROFILE. The thickness of the forms is proportional to the concentration of the species along the profile. The reactions involved in these processes are reported by their numbers given in Table 3. Grey color indicates production, white is for consumption (see text for detail). The significant diffusive fluxes at the SWI are also reported using arrows. As profile is not reported here since PROFILE could not determine statistically significant zones where it could be either produced or consumed from the porewaters owing to the high level of noise in the profile (Fig. $5 \mathrm{~m}$ ).

Figure 7: A) concentration profiles of $\mathrm{Mn}, \mathrm{Fe}, \mathrm{SO}_{4}{ }^{2-}, \mathrm{\Sigma H}_{2} \mathrm{~S}, \mathrm{As}, \mathrm{Co}, \mathrm{Cr}, \mathrm{Ni}, \mathrm{Hg}_{\text {tot }}$ and $\mathrm{MeHg}$ obtained by peeper in the site CB-A. The fit of experimental values, areas and net rates of reactions obtained using PROFILE are also reported. B) Schematic representation of areas and depth integrated rates of production/consumption reactions of dissolved species in porewaters obtained by PROFILE. The thickness of the forms is proportional to the concentration of the species along the profile. The reactions involved in these processes are reported by their numbers given in Table 3. Grey color indicates production, white is for consumption (see text for detail). The significant diffusive fluxes at the SWI are also reported using arrows. The profiles of $\mathrm{Hg}$ and $\mathrm{MeHg}$ correspond to the average of the three replicates presented in the Fig. $5 q-r$.

Figure 8: A) concentration profiles of $\Sigma \mathrm{NO}_{3}, \mathrm{Mn}, \mathrm{Fe}, \mathrm{SO}_{4}{ }^{2-}, \Sigma \mathrm{H}_{2} \mathrm{~S}, \mathrm{As}, \mathrm{Co}, \mathrm{Cr}$ and $\mathrm{Ni}$ obtained by peeper in the site $\mathrm{V}-\mathrm{O}$. The fit of experimental values, areas and net rates of reactions obtained using PROFILE are also reported. B) Schematic representation of areas and depth integrated rates of production/consumption reactions of dissolved species in porewaters obtained by PROFILE. The thickness of the forms is proportional to the concentration of the species along 
the profile. The reactions involved in these processes are reported by their numbers given in Table 3. Grey color indicates production, white is for consumption (see text for detail). The significant diffusive fluxes at the SWI are also reported using arrows.

Figure 9: Concentration profiles of $\mathrm{Ca}, \mathrm{Mg}$ and $\mathrm{SO}_{4}{ }^{2-}$ measured and calculated using the Dittmar's principle and $\mathrm{Na}$ concentration in sites $\mathrm{CB}-\mathrm{O}, \mathrm{CB}-\mathrm{A}$ and $\mathrm{V}-\mathrm{O}$. The horizontal dotted line represents the SWI. The abscissa scale is adjusted for better viewing.

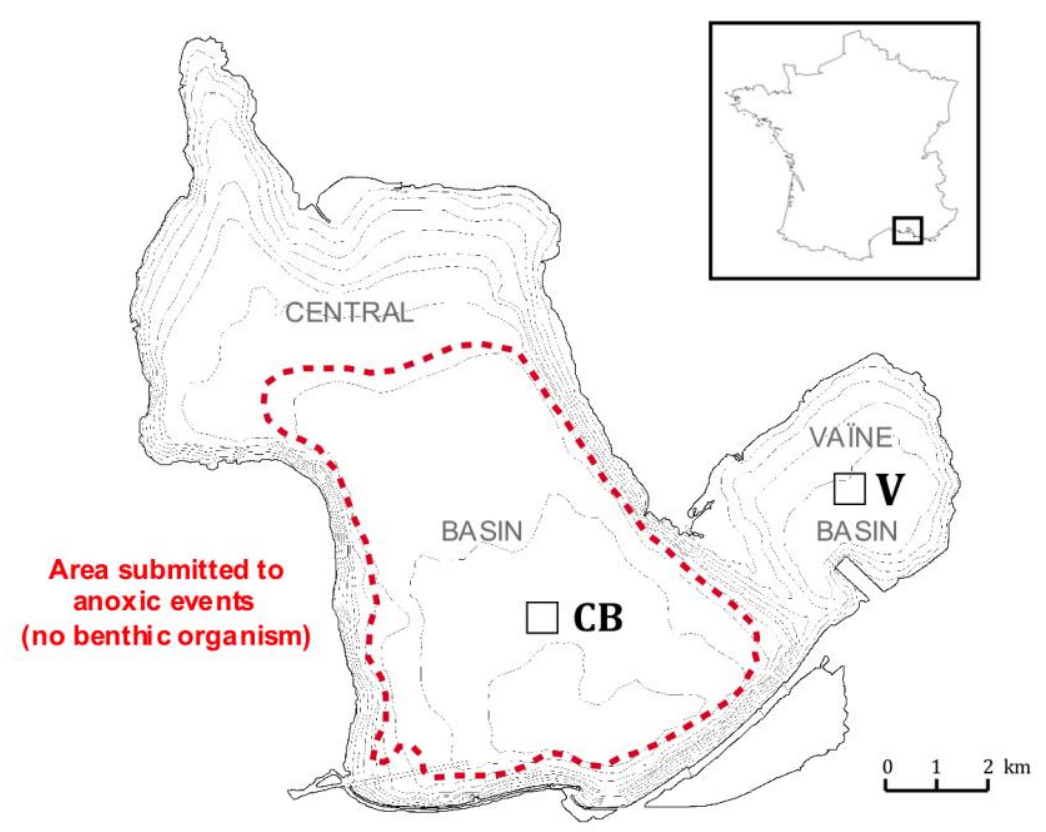

Fig. 1 

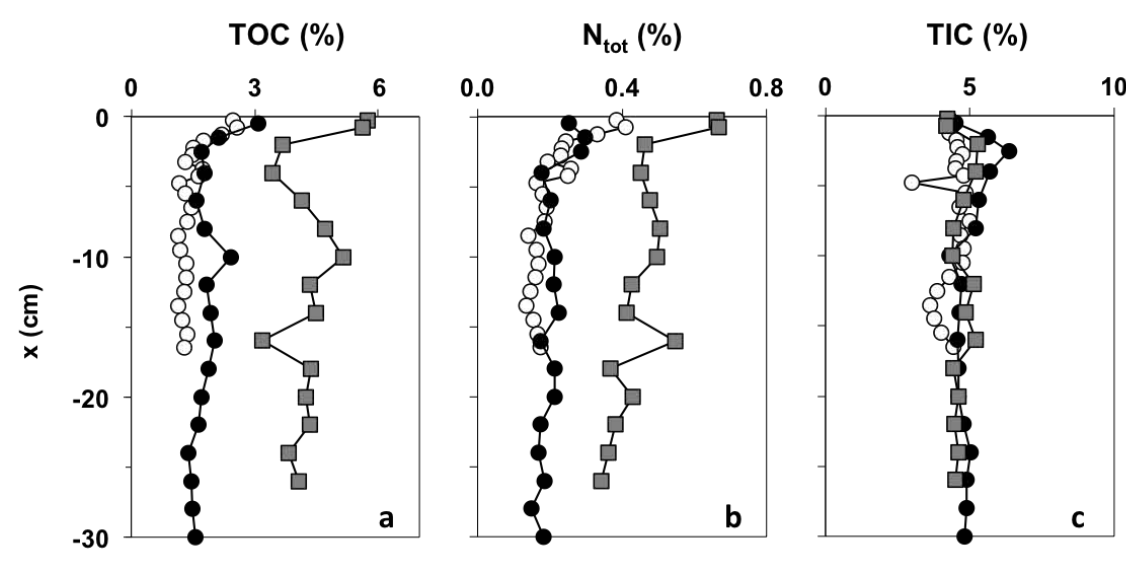

100

Fe $\left(\mathrm{mg} \cdot \mathrm{g}^{-1}\right)$

Mn ( $\left.\mu \mathrm{g} \cdot \mathrm{g}^{-1}\right)$

$\mathrm{S}\left(\mathrm{mg}^{\mathrm{g}} \mathrm{g}^{-1}\right)$
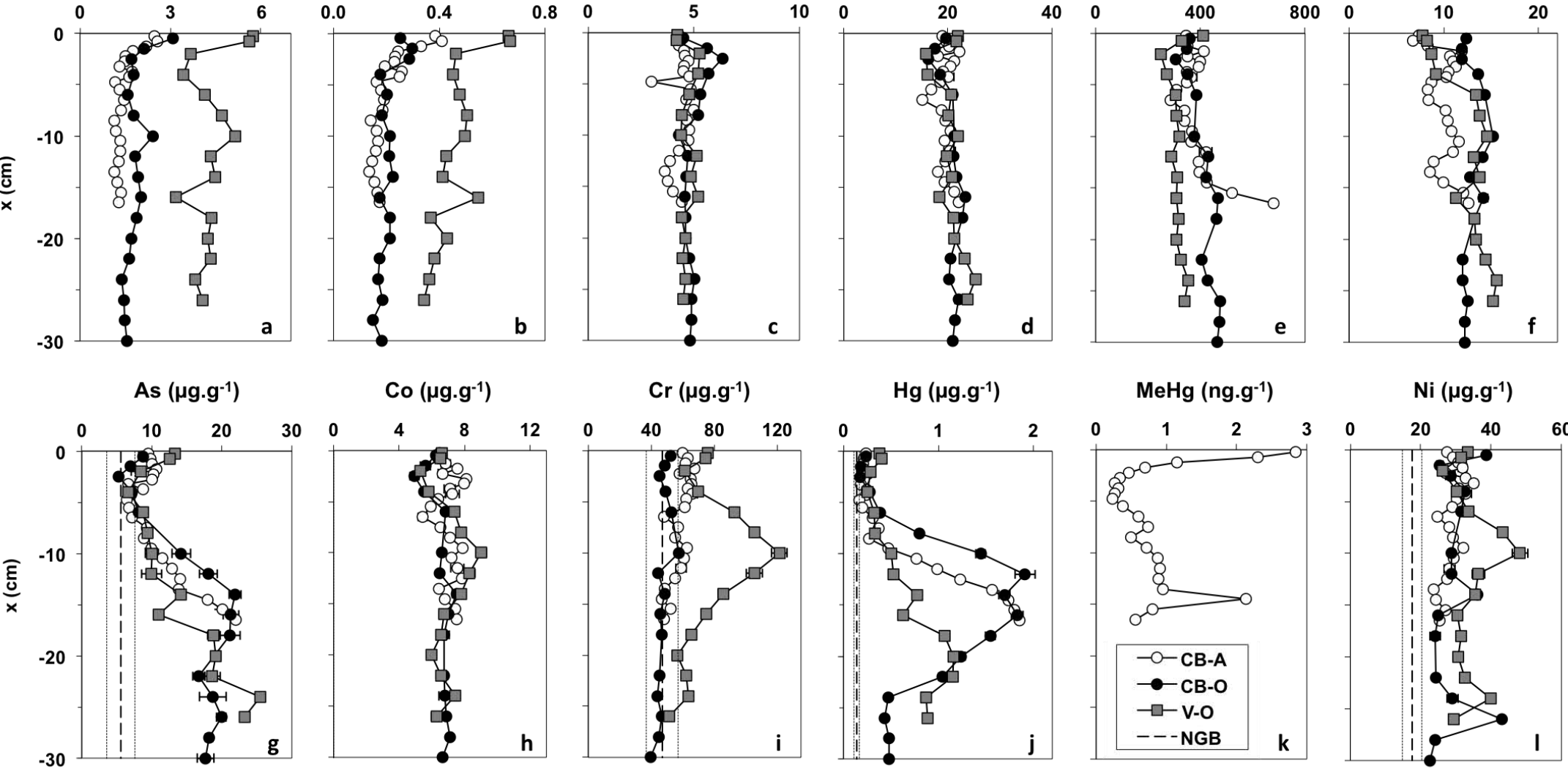

$\mathrm{Ni}\left(\boldsymbol{\mu g} . \mathrm{g}^{-1}\right)$

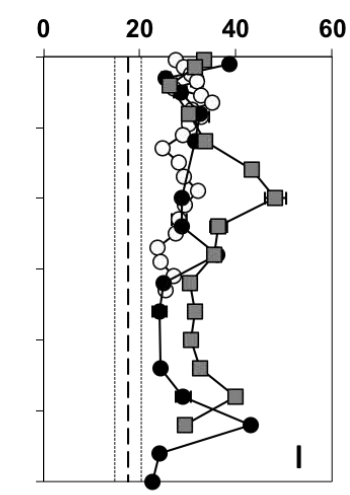

Fig. 2 

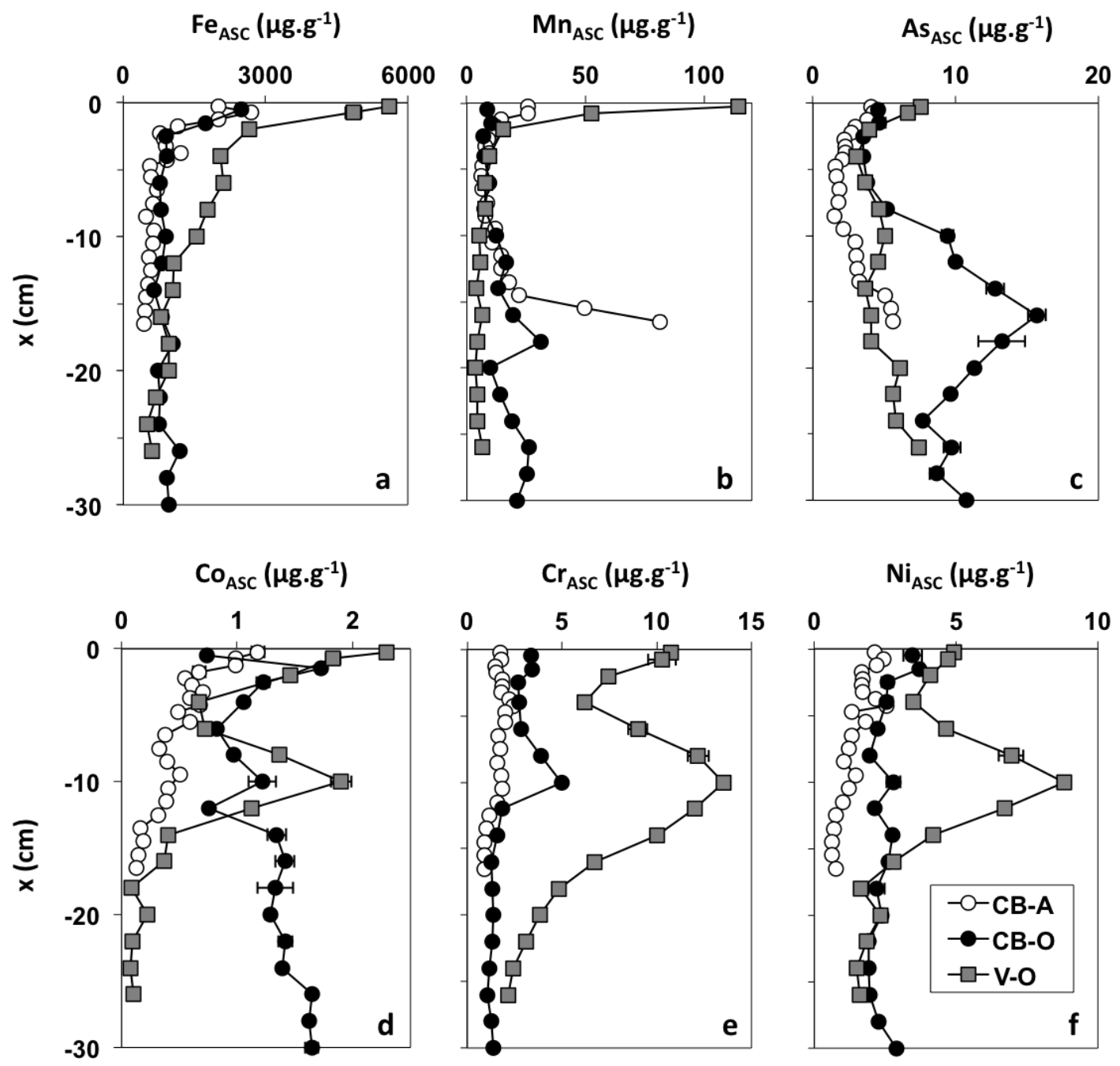

Fig. 3 


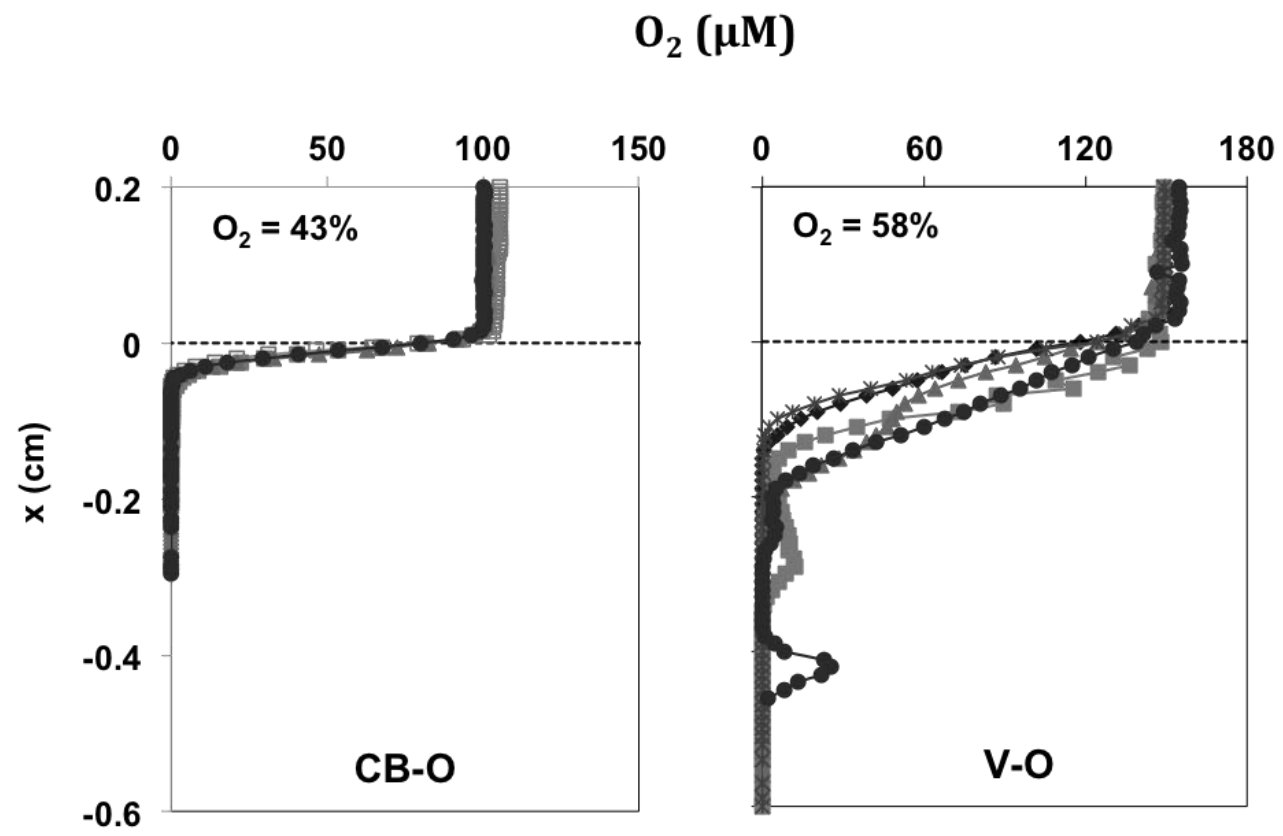

Fig. 4

27 

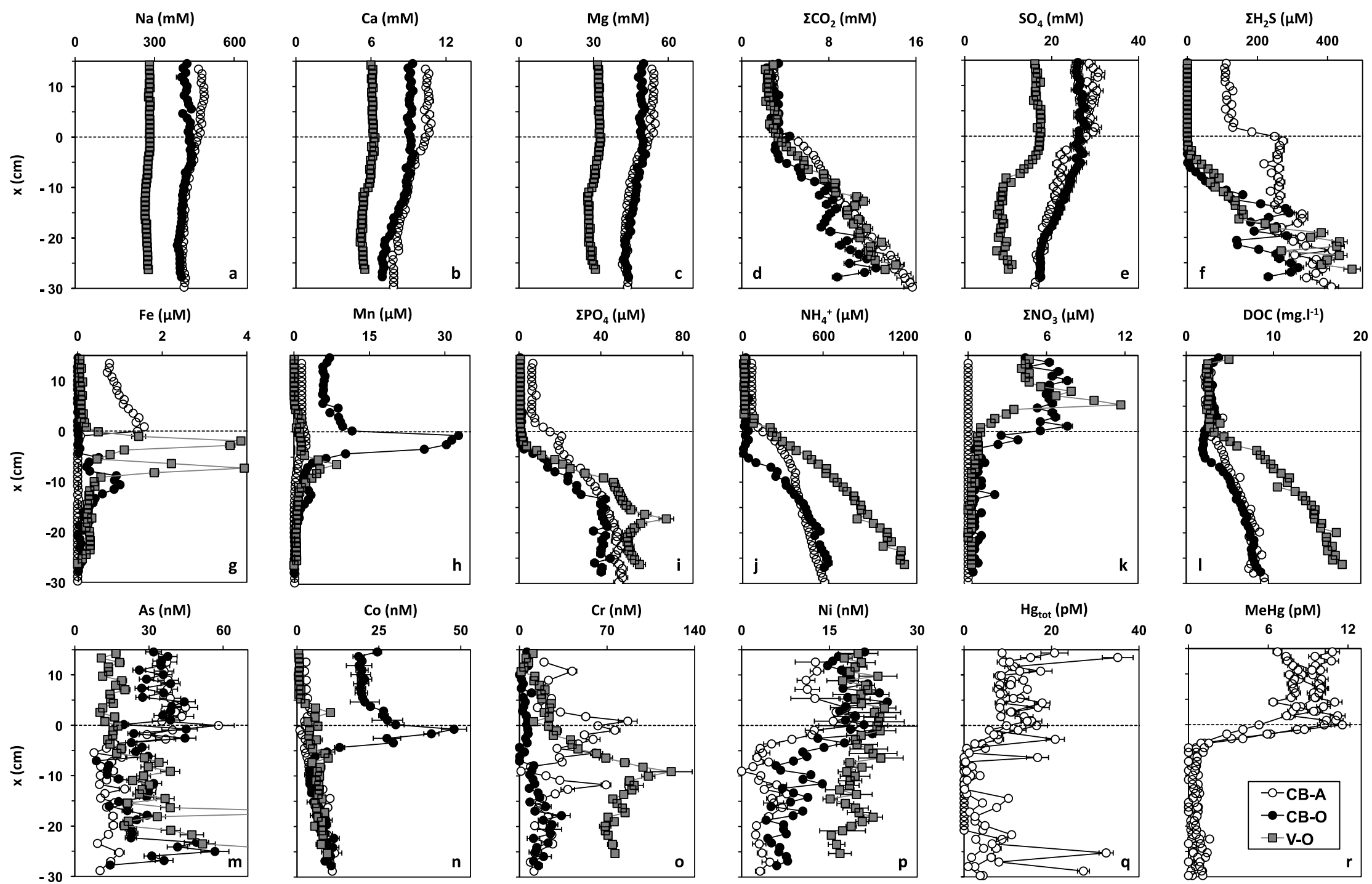

Fig. 5 

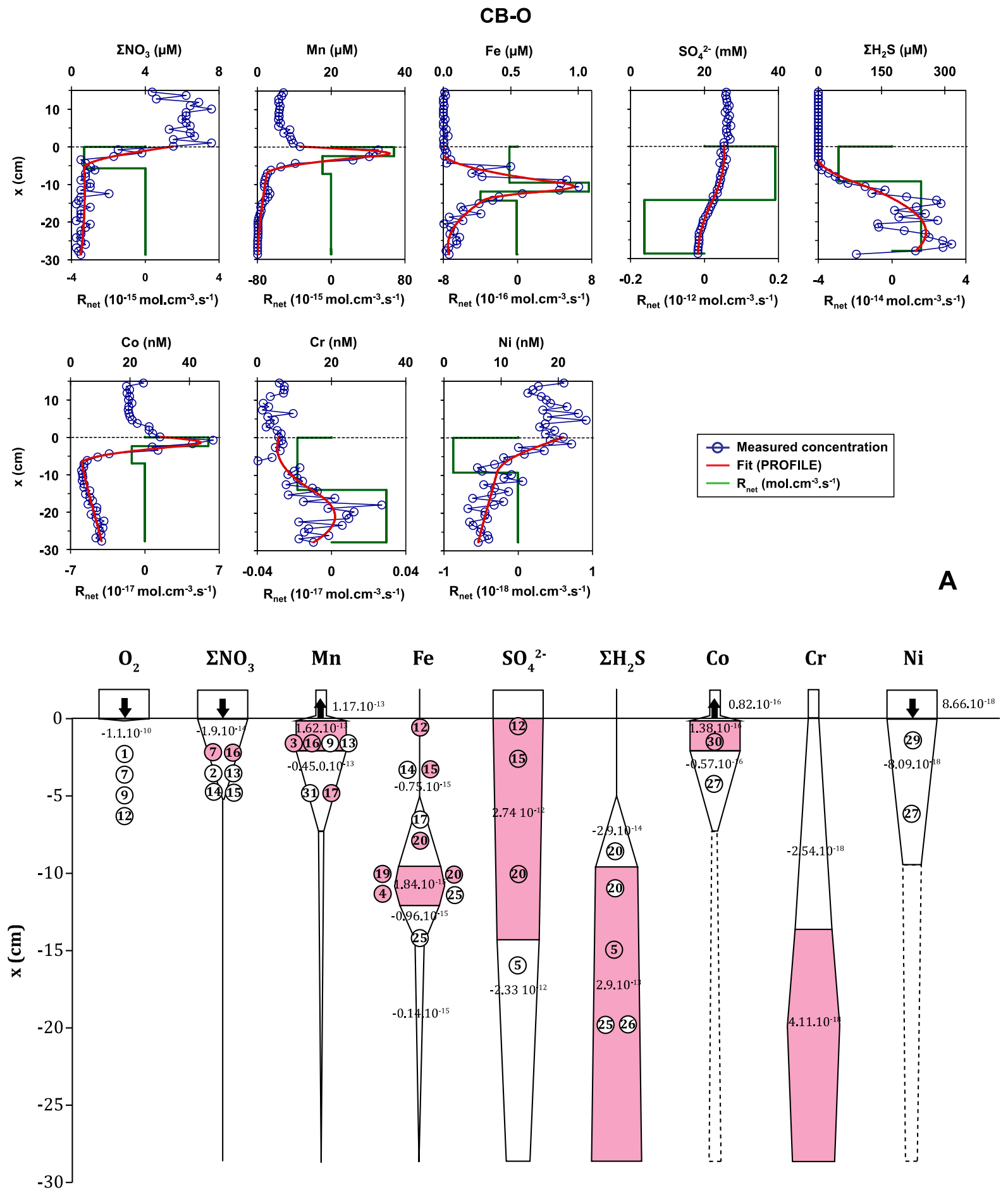

\begin{tabular}{|c|c|c|}
\hline Production zone & (7)/(7) & Consumption/production reactions numbers (Table 3) \\
\hline Consumption zone & $-4.3 .10^{-12}$ & Net depth integrated rates on reactions $\left(\mathrm{R}_{\mathrm{net}^{\prime}} \mathrm{mol} \mathrm{cm}^{-2} \cdot \mathrm{s}^{-1}\right)$ \\
\hline Non significant reaction zone & $\boldsymbol{1}$ & Flux at the SWI $\left(\mathrm{mol} \cdot \mathrm{cm}^{-2} \cdot \mathrm{s}^{-1}\right)$ \\
\hline
\end{tabular}

Fig. 6 

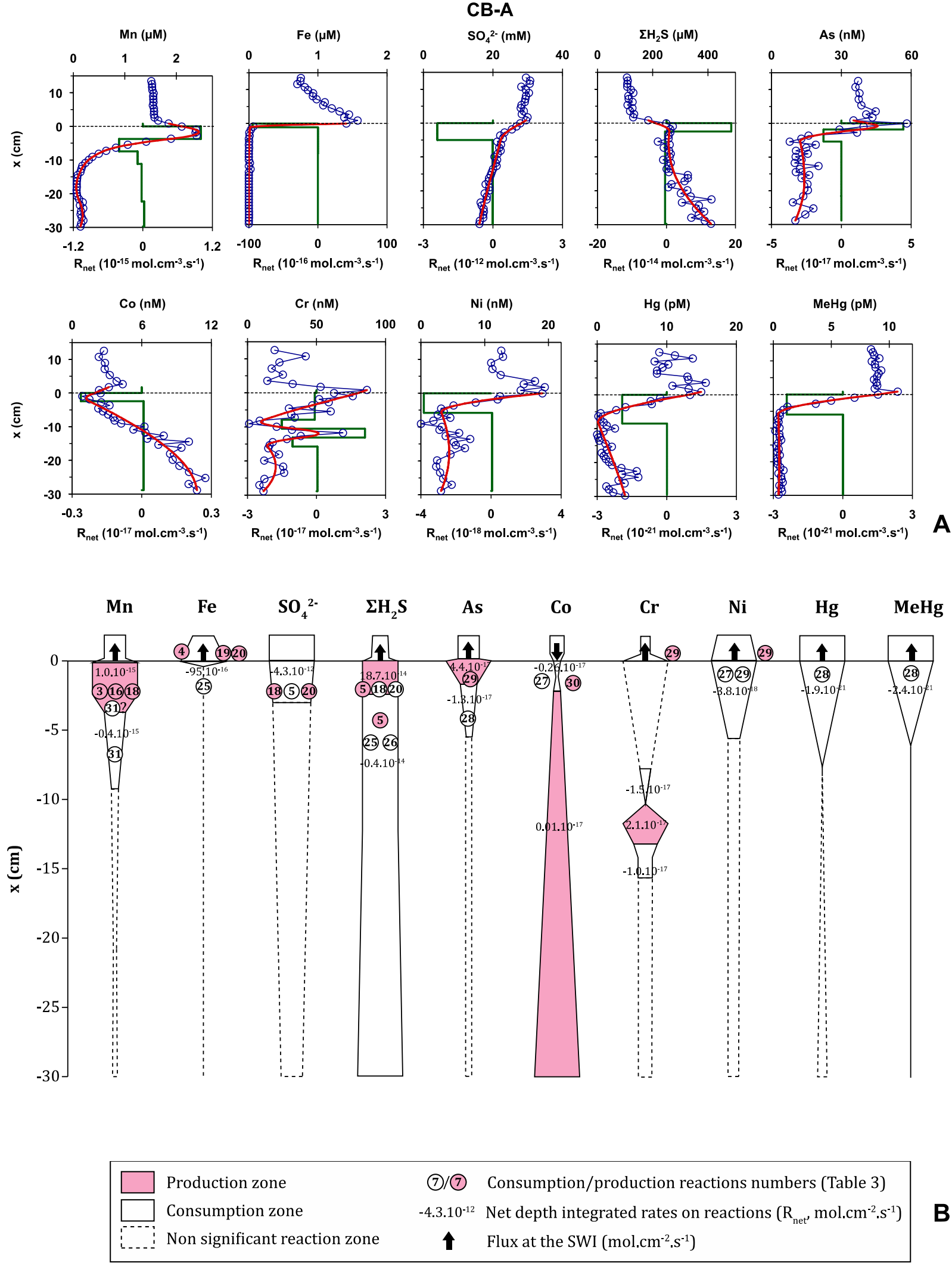

B

Fig. 7 

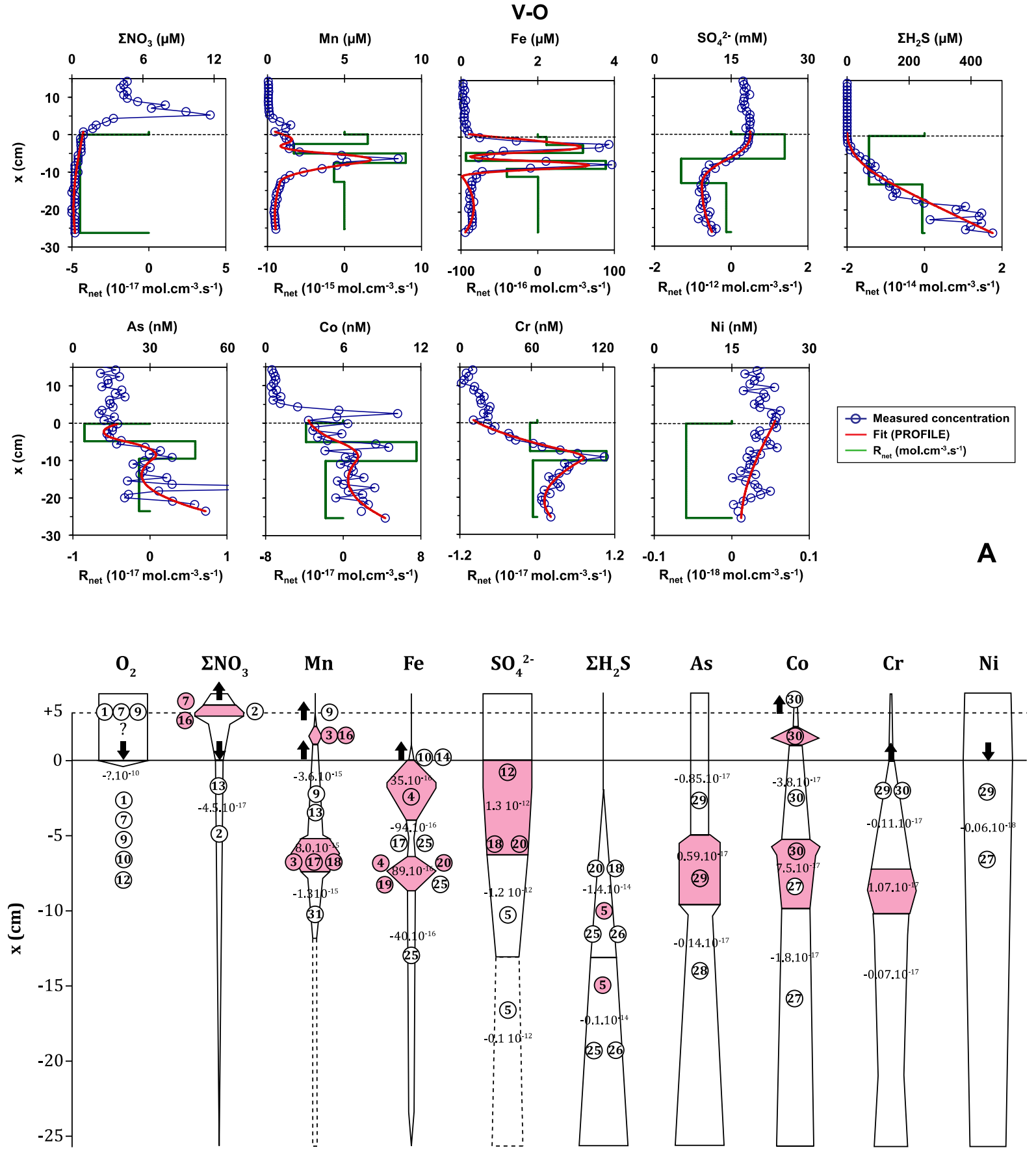

\begin{tabular}{|c|c|c|}
\hline Production zone & (7)/7) & Consumption/production reactions numbers (Table 3 ) \\
\hline Consumption zone & $-4.3 .10^{-12}$ & Net depth integrated rates on reactions $\left(\mathrm{R}_{\text {net }}, \mathrm{mol} \mathrm{cm}^{-2} \cdot \mathrm{s}^{-1}\right)$ \\
\hline Non significant reaction zone & $\boldsymbol{\uparrow}$ & Flux at the SWI $\left(\mathrm{mol} \cdot \mathrm{cm}^{-2} \cdot \mathrm{s}^{-1}\right)$ \\
\hline
\end{tabular}

B

Fig. 8 

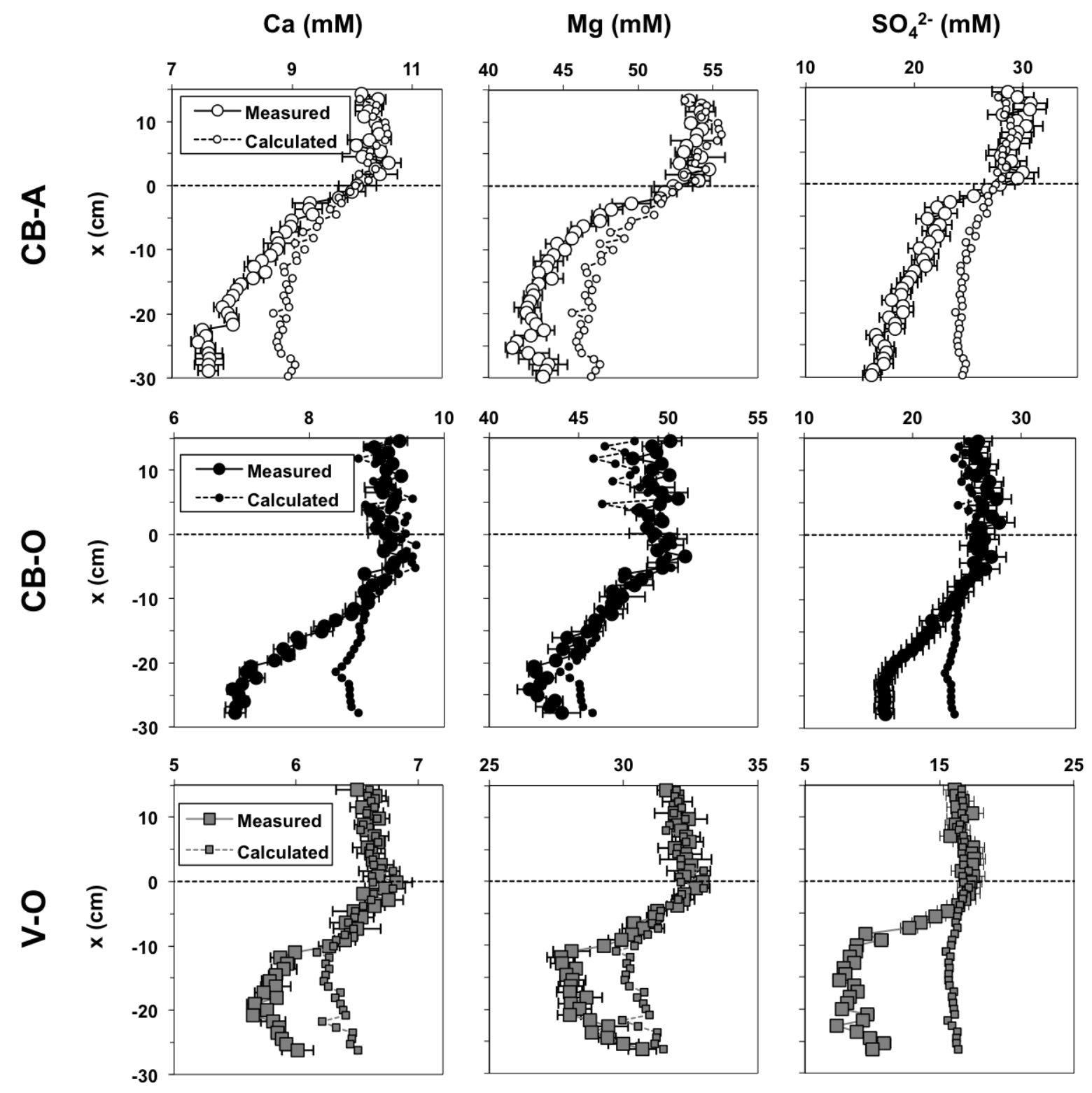

Fig. 9 
Electronic annex - Rigaud et al., Mobility and fluxes of trace elements and nutrients at the sediment-water interface of a lagoon under contrasting water column oxygenation conditions.

\section{EA-1: Supplementary data}

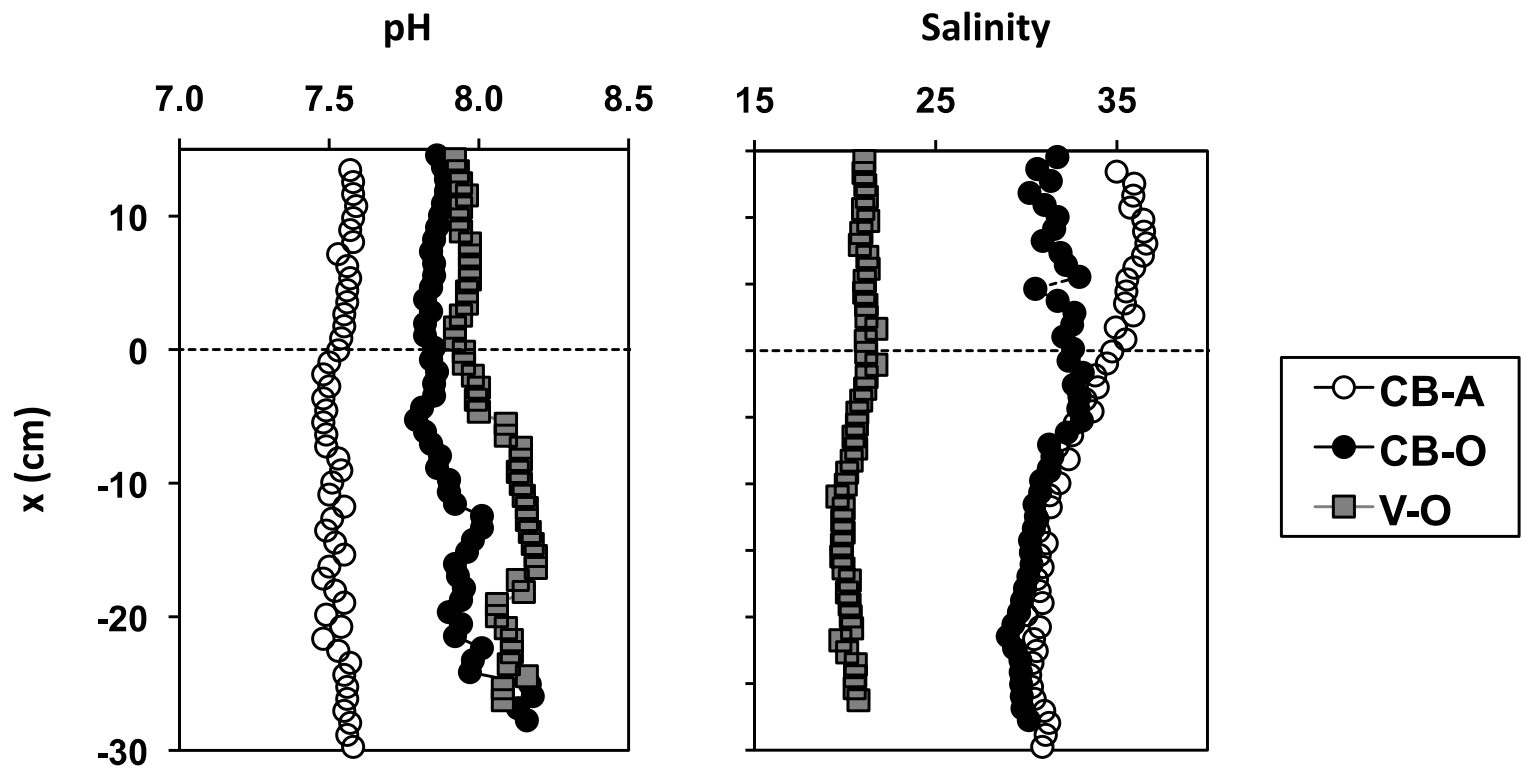

Figure EA-1.1: $\mathrm{pH}$ and salinity profiles in the overlying and pore waters collected by peepers. Salinity was obtained from measured $\mathrm{Na}$ concentrations and Dittmar's principle (Salinity = $\left.[\mathrm{Na}(\mathrm{mmol} / \mathrm{kg})]^{\star} 0.07510\right)$. The horizontal dashed line represents the sediment-water interface.

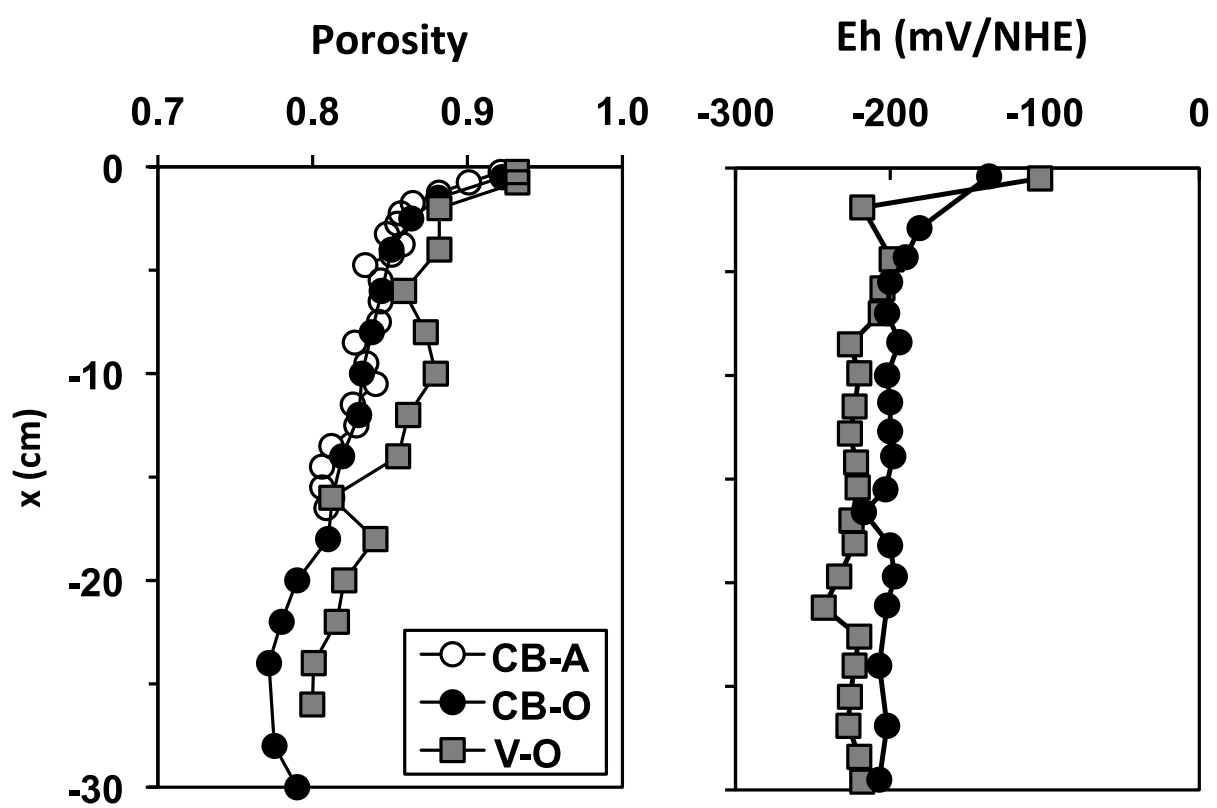

Figure EA-1.2: Porosity and Eh (expressed as $\mathrm{mV}$ normalized to the Standard Hydrogen Electrode) profiles in the sediment cores. The Eh profile was not carried out at anoxic site CB-A and was fixed at $-200 \mathrm{mV}$ for thermodynamic calculations. 


\section{EA-2: Calculation of apparent thermodynamic constants $\left(K_{a p p}\right)$ of trace elements complexation with dissolved organic matter using WHAM-VI}

The apparent thermodynamic constants $\left(\mathrm{K}_{\mathrm{app}}\right)$ of trace elements complexation with fulvic acids (FA) and humic acids (HA) were calculated from the speciation calculated by WHAM VI. For example, for a complexation reaction between the metal $\mathrm{Me}^{2+}$ and the fulvic acid $\mathrm{FA}^{2-}$ forming a complex MeFA (Reaction 1), $\mathrm{K}_{\mathrm{app}}$ is calculated using Equation 1.

$$
\begin{array}{cl}
\mathrm{Me}^{2+}+\mathrm{FA}^{2-}=\mathrm{MeFA} & \text { (Reaction 1) } \\
\log K_{\text {app }}=\log \frac{[\mathrm{MeFA}]}{\left[F A^{2}\right]\left[\mathrm{Me}^{2+}\right]} \div & \text { (Equation 1) }
\end{array}
$$

where $[\mathrm{MeFA}],\left[\mathrm{FA}^{-2}\right]$ and $\left[\mathrm{Me}^{2+}\right]$ are the concentrations $\left(\mathrm{mol}^{-I^{-1}}\right)$ of complex MeFA , fulvic acid $\mathrm{FA}^{2-}$ and free metal $\mathrm{Me}^{2+}$ in solution respectively. The molar concentrations of $\mathrm{FA}$ and $\mathrm{HA}$ in solution were calculated from their respective molecular weights, 650 and $2000 \mathrm{~g} \cdot \mathrm{mol}^{-1}$, and the concentrations of dissolved organic carbon (DOC in $\mathrm{g} . \mathrm{I}^{-1}$ ) according to equations 2 and 3 .

$$
\begin{aligned}
& {\left[F A^{2}\right]=2 \frac{D O C}{650} 0.9} \\
& {\left[H A^{2}\right]=2 \frac{D O C}{2000} 0.1}
\end{aligned}
$$

The $\mathrm{K}_{\mathrm{app}}$ were calculated for all samples in solution obtained in this work. Sulphide was shown to significantly modify the affinity of metals for dissolved organic matter, and two calculations were made: in the presence and absence of $\Sigma \mathrm{H}_{2} \mathrm{~S}$. The $\mathrm{K}_{\text {app }}$ values used in this work correspond to the average of all measurements in both situation (with and without $\Sigma \mathrm{H}_{2} \mathrm{~S}$ ) and are reported with associated standard deviation, in Table EA-1.1. The lack of data concerning the interaction between As and dissolved FA and HA, does not allow us to determine the $\mathrm{K}_{\mathrm{app}}$ for this element. 
Table EA-2.1: Averages and standard deviations of the apparent thermodynamic constants $\left(\mathrm{K}_{\mathrm{app}}\right)$ reactions of trace elements complexation with fulvic acids (FA) and humic acids (HA) calculated from WHAM VI in the presence and absence of $\Sigma \mathrm{H} 2 \mathrm{~S}$. These reactions and $\mathrm{K}_{\mathrm{app}}$ values were also added to the MINTEQ database.

\begin{tabular}{|c|c|c|c|c|}
\hline \multirow[b]{2}{*}{ Reactions } & \multicolumn{2}{|c|}{$\Sigma H_{2} S=O \mu M$} & \multicolumn{2}{|c|}{$\Sigma H_{2} S>0 \mu M$} \\
\hline & $\log K_{\text {app }}$ & s.d. & $\log K_{\text {app }}$ & s.d. \\
\hline $\mathrm{Fe}^{2+}+$ Fulvate $^{2-}=$ FeFulvate & 3.5 & 0.2 & 3.6 & 0.1 \\
\hline $\mathrm{Fe}^{2+}+$ Humate $^{2-}=$ FeHumate & 4.3 & 0.1 & 4.5 & 0.2 \\
\hline $\mathrm{Mn}^{2+}+$ Fulvate $^{2-}=$ MnFulvate & 4.0 & 0.2 & 4.1 & 0.1 \\
\hline $\mathrm{Mn}^{2+}+$ Humate $^{2-}=$ MnHumate & 1.8 & 0.1 & 1.9 & 0.2 \\
\hline $\mathrm{Co}^{2+}+$ Fulvate $^{2-}=$ CoFulvate & 2.8 & 0.2 & 6.4 & 0.2 \\
\hline $\mathrm{Co}^{2+}+$ Humate $^{2-}=$ CoHumate & 3.5 & 0.1 & 6.5 & 0.2 \\
\hline $\mathrm{Cr}^{3+}+$ Fulvate $^{2-}=$ CrFulvate $^{+}$ & 11.1 & 1.8 & 11.7 & 2.1 \\
\hline $\mathrm{Cr}^{3+}+$ Humate $^{2-}=$ CrHumate $^{+}$ & 13.0 & 2.1 & 13.5 & 2.1 \\
\hline $\mathrm{Hg}^{2+}+$ Fulvate $^{2-}=$ HgFulvate & & & 32.7 & 0.3 \\
\hline $\mathrm{Hg}^{2+}+$ Humate $^{2-}=$ HgHumate & & & 35.8 & 1.3 \\
\hline $\mathrm{MeHg}^{+}+$Fulvate $^{2-}=$ MeHgFulvate $^{-}$ & & & 10.3 & 0.2 \\
\hline $\mathrm{MeHg}^{+}+$Humate $^{2-}=$ MeHgHumate $^{-}$ & & & 10.4 & 0.2 \\
\hline $\mathrm{Ni}^{2+}+$ Fulvate $^{2-}=$ NiFulvate & 3.4 & 0.2 & 5.6 & 0.2 \\
\hline $\mathrm{Ni}^{2+}+$ Humate $^{2-}=$ NiHumate & 3.9 & 0.1 & 5.7 & 0.2 \\
\hline
\end{tabular}




\section{EA-3: Reactions and associated thermodynamic constants $\left(\mathrm{I}=0 \mathrm{M} ; \mathrm{T}=25^{\circ} \mathrm{C}\right)$ added to the default WHAM-VI and MINTEQ databases for aqueous species speciation calculations.}

\begin{tabular}{|c|c|c|c|}
\hline $\mathbf{N}^{\circ}$ & Reactions & $\log k$ & References \\
\hline \multicolumn{4}{|c|}{ Carbonates } \\
\hline 1 & $\mathrm{CO}_{3}^{2-}+\mathrm{H}^{+}=\mathrm{HCO}_{3}^{-}$ & 9.37 & Boudreau, 1997 \\
\hline 2 & $\mathrm{CO}_{3}^{2-}+2 \mathrm{H}^{+}=\mathrm{H}_{2} \mathrm{CO}_{3}$ & 15.37 & Boudreau, 1997 \\
\hline \multicolumn{4}{|c|}{ Phosphates } \\
\hline 3 & $\mathrm{PO}_{4}^{3-}+\mathrm{H}^{+}=\mathrm{HPO}_{4}^{2-}$ & 12.34 & Boudreau, 1997 \\
\hline 4 & $\mathrm{PO}_{4}^{3-}+2 \mathrm{H}^{+}=\mathrm{H}_{2} \mathrm{PO}_{4}^{-}$ & 19.54 & Boudreau, 1997 \\
\hline 5 & $\mathrm{PO}_{4}^{3-}+3 \mathrm{H}^{+}=\mathrm{H}_{3} \mathrm{PO}_{4}$ & 21.69 & Boudreau, 1997 \\
\hline \multicolumn{4}{|c|}{$S(-2) / S(6)$} \\
\hline 6 & $\mathrm{HS}^{-}+\mathrm{H}^{+}=\mathrm{H}_{2} \mathrm{~S}$ & 6.98 & Boudreau, 1997 \\
\hline 7 & $\mathrm{HS}^{-}=\mathrm{S}^{2-}+\mathrm{H}^{+}$ & -18.57 & Schoonen and Barnes, 1998 (Balistrieri, 1992) \\
\hline \multicolumn{4}{|c|}{ ele } \\
\hline 9 & $\mathrm{Fe}^{2+}+\mathrm{HS}^{-}=\mathrm{Fe}(\mathrm{HS})^{+}$ & 5.2 & Luther et al., 1996 (Rickard and Morse, 2005) \\
\hline 10 & $\mathrm{Fe}^{2+}+2 \mathrm{HS}^{-}=\mathrm{Fe}(\mathrm{HS})_{2}$ & 8.542 & Dyrssen, 1985 (Taillefert et al., 2000) \\
\hline 11 & $\mathrm{Fe}^{2+}+3 \mathrm{HS}^{-}=\mathrm{Fe}(\mathrm{HS})_{3^{-}}^{-}$ & 9.808 & Allison et al., 1989 (Taillefert et al., 2000) \\
\hline $\begin{array}{r}12 \\
M\end{array}$ & $\mathrm{Fe}^{2+}+2 \mathrm{HS}^{-}=\mathrm{FeHS}_{2}^{-}+\mathrm{H}^{+}$ & 2.262 & Dyrssen, 1985 (Taillefert et al., 2000) \\
\hline 13 & $\mathrm{Mn}^{2+}+\mathrm{HS}^{-}=\mathrm{MnS}+\mathrm{H}^{+}$ & -2.08 & Balistrieri, 1992 \\
\hline 14 & $\mathrm{Mn}^{2+}+\mathrm{HS}^{-}=\mathrm{Mn}(\mathrm{HS})^{+}$ & -0.35 & Balistrieri, 1992 \\
\hline 15 & $\mathrm{Mn}^{2+}+2 \mathrm{HS}^{-}=\mathrm{Mn}(\mathrm{HS})_{2}$ & 7.22 & Balistrieri, 1992 \\
\hline 16 & $\mathrm{Mn}^{2+}+3 \mathrm{HS}^{-}=\mathrm{Mn}(\mathrm{HS})_{3^{-}}^{-}$ & 8.07 & Balistrieri, 1992 \\
\hline $\begin{array}{r}17 \\
\text { As }\end{array}$ & \multicolumn{2}{|l|}{ 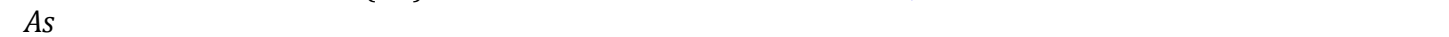 } & Balistrieri, 1992 \\
\hline 18 & $\mathrm{AsO}_{3}{ }^{3-}+\mathrm{H}^{+}=\mathrm{HAsO}_{3}{ }^{2-}$ & 15 & Nordstrom and Archer, 2003 (Couture et al., 2010) \\
\hline 19 & $\mathrm{AsO}_{3}^{3-}+2 \mathrm{H}^{+}=\mathrm{H}_{2} \mathrm{AsO}_{3}^{-}$ & 29.2 & Nordstrom and Archer, 2003 (Couture et al., 2010) \\
\hline 20 & $\mathrm{AsO}_{3}{ }^{3-}+3 \mathrm{H}^{+}=\mathrm{H}_{3} \mathrm{AsO}_{3}$ & 38.3 & Nordstrom and Archer, 2003 (Couture et al., 2010) \\
\hline 21 & $\mathrm{AsO}_{4}^{3-}+\mathrm{H}^{+}=\mathrm{HAsO}_{4}^{2-}$ & 11.80 & Nordstrom and Archer, 2003 (Couture et al., 2010) \\
\hline 22 & $\mathrm{AsO}_{4}^{3-}+2 \mathrm{H}^{+}=\mathrm{H}_{2} \mathrm{AsO}_{4}^{-}$ & 18.79 & Nordstrom and Archer, 2003 (Couture et al., 2010) \\
\hline 23 & $\mathrm{AsO}_{4}^{3-}+3 \mathrm{H}^{+}=\mathrm{H}_{3} \mathrm{AsO}_{4}$ & 21.09 & Nordstrom and Archer, 2003 (Couture et al., 2010) \\
\hline 24 & $\mathrm{AsO}_{4}{ }^{3-}+2 \mathrm{H}^{+}+\mathrm{Fe}^{2+}=\mathrm{FeH}_{2} \mathrm{AsO}_{4}^{+}$ & 5.15 & Whiting, 1992 (Couture et al., 2010) \\
\hline 25 & $\mathrm{AsO}_{4}^{3-}+\mathrm{H}^{+}+\mathrm{Fe}^{2+}=\mathrm{FeHAsO}_{4}$ & 6.1 & Whiting, 1992 (Couture et al., 2010) \\
\hline 26 & $\mathrm{AsO}_{4}^{3-}+\mathrm{Fe}^{2+}=\mathrm{FeAsO}_{4}^{-}$ & -13.6 & Whiting, 1992 (Couture et al., 2010) \\
\hline 27 & $\mathrm{AsO}_{4}^{3-}+\mathrm{H}^{+}+\mathrm{Mn}^{2+}=\mathrm{MnHAsO}_{4}$ & 15.54 & Whiting, 1992 (Couture et al., 2010) \\
\hline 28 & $\mathrm{AsO}_{4}^{3-}+\mathrm{Mn}^{2+}=\mathrm{MnAsO}_{4}^{-}$ & 6.1 & Whiting, 1992 (Couture et al., 2010) \\
\hline 29 & $\mathrm{AsO}_{4}^{3-}+\mathrm{Mg}^{2+}=\mathrm{MgAsO}_{4}^{-}$ & 6.3 & Whiting, 1992 (Couture et al., 2010) \\
\hline 30 & $\mathrm{AsO}_{4}^{3-}+\mathrm{H}^{+}+\mathrm{Mg}^{2+}=\mathrm{MgHAsO}_{4}$ & 14.7 & Whiting, 1992 (Couture et al., 2010) \\
\hline 31 & $\mathrm{AsO}_{4}^{3-}+2 \mathrm{H}^{+}+\mathrm{Ca}^{2+}=\mathrm{CaH}_{2} \mathrm{AsO}_{4}^{+}$ & 20.09 & Bothe and Brown, 1999 (Couture et al., 2010) \\
\hline 32 & $\mathrm{AsO}_{4}^{3-}+\mathrm{H}^{+}+\mathrm{Ca}^{2+}=\mathrm{CaHAsO}_{4}$ & 14.46 & Bothe and Brown, 1999 (Couture et al., 2010) \\
\hline 33 & $\mathrm{AsO}_{4}^{3-}+\mathrm{Ca}^{2+}=\mathrm{CaAsO}_{4}^{-}$ & 4.36 & Bothe and Brown, 1999 (Couture et al., 2010) \\
\hline 34 & $\mathrm{AsO}_{3}{ }^{3-}+\mathrm{HS}^{-}+4 \mathrm{H}^{+}=\mathrm{H}_{3} \mathrm{AsSO}_{2}+\mathrm{H}_{2} \mathrm{O}$ & 49.88 & Vlassopoulos et al., 2010 \\
\hline 35 & $\mathrm{AsO}_{3}{ }^{3-}+\mathrm{HS}^{-}+3 \mathrm{H}^{+}=\mathrm{H}_{2} \mathrm{AsSO}_{2}^{-}+\mathrm{H}_{2} \mathrm{O}$ & 44.62 & Vlassopoulos et al., 2010 \\
\hline 36 & $\mathrm{AsO}_{3}{ }^{3-}+2 \mathrm{HS}^{-}+3 \mathrm{H}^{+}=\mathrm{HAsS}_{2} \mathrm{O}^{2-}+2 \mathrm{H}_{2} \mathrm{O}$ & 46.9 & Wilkin et al., 2003 (Couture et al., 2010) \\
\hline 37 & $\mathrm{AsO}_{3}{ }^{3-}+3 \mathrm{HS}^{-}+4 \mathrm{H}^{+}=\mathrm{HAsS}_{3}{ }^{2-}+3 \mathrm{H}_{2} \mathrm{O}$ & 58.7 & Wilkin et al., 2003 (Couture et al., 2010) \\
\hline 38 & $\mathrm{AsO}_{3}{ }^{3-}+3 \mathrm{HS}^{-}+3 \mathrm{H}^{+}=\mathrm{AsS}_{3} 3^{--}+3 \mathrm{H}_{2} \mathrm{O}$ & 50.8 & Wilkin et al., 2003 (Couture et al., 2010) \\
\hline 39 & $\mathrm{AsO}_{3}{ }^{3-}+4 \mathrm{HS}^{-}+6 \mathrm{H}^{+}=\mathrm{As}(\mathrm{SH})_{4}^{-}+3 \mathrm{H}_{2} \mathrm{O}$ & 74.8 & Wilkin et al., 2003 (Couture et al., 2010) \\
\hline 40 & $\mathrm{AsO}_{3}{ }^{3-}+3 \mathrm{HS}^{-}+6 \mathrm{H}^{+}=\mathrm{H}_{3} \mathrm{AsS}_{3}+3 \mathrm{H}_{2} \mathrm{O}$ & 66.91 & Vlassopoulos et al., 2010 \\
\hline 41 & $\mathrm{AsO}_{3}{ }^{3-}+3 \mathrm{HS}^{-}+5 \mathrm{H}^{+}=\mathrm{H}_{2} \mathrm{AsS}_{3}-3 \mathrm{H}_{2} \mathrm{O}$ & 64.77 & Vlassopoulos et al., 2010 \\
\hline 42 & $\mathrm{AsO}_{3}{ }^{3-}+3 \mathrm{HS}^{-}+4 \mathrm{H}^{+}=\mathrm{HAsS}_{3}{ }^{2-}+3 \mathrm{H}_{2} \mathrm{O}$ & 57.58 & Vlassopoulos et al., 2010 \\
\hline 43 & $\mathrm{Co}^{2+}+\mathrm{S}^{2-}=\mathrm{CoS}$ & 21.88 & Balistrieri, 1992 \\
\hline 44 & $\mathrm{Co}^{2+}+\mathrm{S}^{2-}+\mathrm{H}^{+}=\mathrm{Co}(\mathrm{HS})^{+}$ & 23.61 & Balistrieri, 1992 \\
\hline 45 & $\mathrm{Co}^{2+}+2 \mathrm{~S}^{2-}+2 \mathrm{H}^{+}=\mathrm{Co}(\mathrm{HS})_{2}$ & 49.75 & Balistrieri, 1992 \\
\hline 46 & $\mathrm{Co}^{2+}+3 \mathrm{~S}^{2-}+3 \mathrm{H}^{+}=\mathrm{Co}(\mathrm{HS})_{3^{-}}$ & 70.17 & Balistrieri, 1992 \\
\hline $\begin{array}{r}47 \\
H\end{array}$ & $\mathrm{Co}^{2+}+4 \mathrm{~S}^{2-}+4 \mathrm{H}^{+}=\mathrm{Co}(\mathrm{HS})_{4}^{2-}$ & 90.29 & Balistrieri, 1992 \\
\hline 48 & $\mathrm{Hg}^{2+}+2 \mathrm{HS}^{-}=\mathrm{Hg}(\mathrm{HS})_{2}$ & 40.37 & Jay et al., 2000 (Feyte et al., 2011) \\
\hline 49 & $\mathrm{Hg}^{2+}+2 \mathrm{HS}^{-}+\mathrm{OH}^{-}=\mathrm{HgS}(\mathrm{HS})^{-}+\mathrm{H}_{2} \mathrm{O}$ & 48.6 & Jay et al., 2000 (Feyte et al., 2011) \\
\hline 50 & $\mathrm{Hg}^{2+}+2 \mathrm{HS}^{-}+2 \mathrm{OH}^{-}=\mathrm{HgS}_{2}{ }^{2-}+2 \mathrm{H}_{2} \mathrm{O}$ & 53.56 & Jay et al., 2000 (Feyte et al., 2011) \\
\hline 51 & $\mathrm{Hg}^{2+}+\mathrm{HS}^{-}=\mathrm{HgSH}^{+}$ & 22.3 & Jay et al., 2000 (Feyte et al., 2011) \\
\hline
\end{tabular}




\begin{tabular}{|c|c|c|c|}
\hline 52 & $\mathrm{Hg}^{2+}+\mathrm{HS}^{-}+\mathrm{OH}^{-}=\mathrm{HgS}+\mathrm{H}_{2} \mathrm{O}$ & 43.8 & Jay et al., 2000 (Feyte et al., 2011) \\
\hline 53 & $\mathrm{Hg}^{2+}+\mathrm{OH}^{-}=\mathrm{HgOH}^{+}$ & 10.6 & Powell et al., 2005 (Feyte et al., 2010) \\
\hline 54 & $\mathrm{Hg}^{2+}+2 \mathrm{OH}^{-}=\mathrm{Hg}(\mathrm{OH})_{2}$ & 22.02 & Powell et al., 2005 (Feyte et al., 2010) \\
\hline 55 & $\mathrm{Hg}^{2+}+3 \mathrm{OH}^{-}=\mathrm{Hg}(\mathrm{OH})_{3}^{-}$ & 20.9 & Powell et al., 2005 (Feyte et al., 2010) \\
\hline 56 & $\mathrm{Hg}^{2+}+\mathrm{Cl}^{-}+\mathrm{OH}^{-}=\mathrm{HgClOH}$ & $18.27^{\mathrm{a}}$ & Martell et al., 1998 (Merritt and Amirbahman, 2007) \\
\hline 57 & $\mathrm{Hg}^{2+}+\mathrm{Cl}^{-}=\mathrm{HgCl}+$ & 7.3 & Powell et al., 2005 (Feyte et al., 2010) \\
\hline 58 & $\mathrm{Hg}^{2+}+2 \mathrm{Cl}^{-}=\mathrm{HgCl}_{2}$ & 14.0 & Powell et al., 2005 (Feyte et al., 2010) \\
\hline 59 & $\mathrm{Hg}^{2+}+3 \mathrm{Cl}^{-}=\mathrm{HgCl}_{3}^{-}$ & 14.93 & Powell et al., 2005 (Feyte et al., 2010) \\
\hline 60 & $\mathrm{Hg}^{2+}+4 \mathrm{Cl}^{-}=\mathrm{HgCl}_{4}^{2-}$ & 15.5 & Powell et al., 2005 (Feyte et al., 2010) \\
\hline 61 & $\mathrm{Hg}^{2+}+\mathrm{SO}_{4}^{2-}=\mathrm{HgSO}_{4}$ & 2.6 & Powell et al., 2005 (Feyte et al., 2010) \\
\hline 62 & $\mathrm{Hg}^{2+}+\mathrm{CO}_{3}^{2-}=\mathrm{HgCO}_{3}$ & 11.51 & Powell et al., 2005 (Feyte et al., 2010) \\
\hline 63 & $\mathrm{Hg}^{2+}+\mathrm{OH}^{-}+\mathrm{CO}_{3}^{2-}=\mathrm{Hg}(\mathrm{OH}) \mathrm{CO}_{3}^{-}$ & 19.34 & Powell et al., 2005 (Feyte et al., 2010) \\
\hline 64 & $\mathrm{Hg}^{2+}+\mathrm{H}^{+}+\mathrm{CO}_{3}^{2-}=\mathrm{HgHCO}_{3}+$ & 15.84 & Powell et al., 2005 (Feyte et al., 2010) \\
\hline & $\mathrm{Hg}^{2+}+2 \mathrm{CO}_{3}{ }^{2-}=\mathrm{Hg}\left(\mathrm{CO}_{3}\right)_{2}{ }^{2-}$ & 15.58 & Martell et al., 2001 (Feyte et al., 2011) \\
\hline 66 & $\mathrm{MeHg}^{+}+\mathrm{HS}^{-}=\mathrm{MeHgHS}$ & 14.5 & Loux et al., 2007 (Feyte et al., 2011) \\
\hline 67 & $\mathrm{MeHg}^{+}+\mathrm{HS}^{-}=\mathrm{MeHgS}^{-}+\mathrm{H}^{+}$ & $7.0^{\mathrm{a}}$ & Martell et al., 2003 (Goulet et al., 2007) \\
\hline 68 & $2 \mathrm{MeHg}^{+}+\mathrm{HS}^{-}=(\mathrm{MeHg})_{2} \mathrm{~S}+\mathrm{H}^{+}$ & $23.3^{\mathrm{a}}$ & Martell et al., 2003 (Goulet et al., 2007) \\
\hline 69 & $3 \mathrm{MeHg}^{+}+\mathrm{HS}^{-}=(\mathrm{MeHg})_{3} \mathrm{~S}++\mathrm{H}^{+}$ & $30.3^{a}$ & Martell et al., 2003 (Goulet et al., 2007) \\
\hline 70 & $\mathrm{MeHg}^{+}+\mathrm{OH}^{-}=\mathrm{MeHgOH}$ & 9.47 & De Robertis et al., 1998 (Feyte et al., 2010) \\
\hline 71 & $2 \mathrm{MeHg}^{+}+\mathrm{OH}^{-}=(\mathrm{MeHg})_{2} \mathrm{OH}^{+}$ & 11.85 & De Robertis et al., 1998 (Feyte et al., 2010) \\
\hline 72 & $\mathrm{MeHg}^{+}+\mathrm{CO}_{3}^{2-}=\mathrm{MeHgCO}_{3}^{-}$ & 6.1 & Rabenstein et al., 1976 (Feyte et al., 2010) \\
\hline 73 & $\mathrm{MeHg}^{+}+\mathrm{H}^{+}+\mathrm{CO}_{3}^{2-}=\mathrm{MeHgHCO}_{3}$ & 12.95 & Loux et al., 2007 (Feyte et al., 2010) \\
\hline 74 & $\mathrm{MeHg}^{+}+\mathrm{Cl}^{-}=\mathrm{MeHgCl}$ & 5.45 & De Robertis et al., 1998 (Feyte et al., 2010) \\
\hline 75 & $\mathrm{MeHg}^{+}+\mathrm{SO}_{4}^{2-}=\mathrm{MeHgSO}_{4}^{-}$ & 2.64 & De Robertis et al., 1998 (Feyte et al., 2010) \\
\hline & $\mathrm{MeHg}^{+}+\mathrm{HPO}_{4}^{2-}=\mathrm{MeHgHPO}_{4}^{-}$ & 5.48 & Amirbahman et al., 2002 (Tipping et al., 2007) \\
\hline 77 & $\mathrm{Ni}^{2+}+\mathrm{S}^{2-}=\mathrm{NiS}$ & 20.99 & Balistrieri, 1992 \\
\hline 78 & $\mathrm{Ni}^{2+}+\mathrm{S}^{2-}+\mathrm{H}^{+}=\mathrm{Ni}(\mathrm{HS})^{+}$ & 22.73 & Balistrieri, 1992 \\
\hline 79 & $\mathrm{Ni}^{2+}+2 \mathrm{~S}^{2-}+2 \mathrm{H}^{+}=\mathrm{Ni}(\mathrm{HS})_{2}$ & 48.87 & Balistrieri, 1992 \\
\hline 80 & $\mathrm{Ni}^{2+}+3 \mathrm{~S}^{2-}+3 \mathrm{H}^{+}=\mathrm{Ni}(\mathrm{HS})_{3}^{-}$ & 69.29 & Balistrieri, 1992 \\
\hline 81 & $\mathrm{Ni}^{2+}+4 \mathrm{~S}^{2-}+4 \mathrm{H}^{+}=\mathrm{Ni}(\mathrm{HS})_{4}^{2-}$ & 89.41 & Balistrieri, 1992 \\
\hline
\end{tabular}

(a) $\mathrm{I}=0.01 \mathrm{M}$ 


\section{EA-4: Dissolution/precipitation reactions and associated thermodynamic constants (I $=0 \mathrm{M} ; \mathrm{T}=25^{\circ} \mathrm{C}$ ) added to the default MINTEQ databases for saturation indexes calculations.}

\begin{tabular}{|c|c|c|c|c|}
\hline $\mathbf{N}^{\circ}$ & Minerals & Reactions & $\log k$ & Reférences \\
\hline & C & & & \\
\hline 1 & Calcite & $\mathrm{CaCO}_{3}=\mathrm{Ca}^{2+}+\mathrm{CO}_{3}^{2-}$ & -8.48 & Boudreau, 1997 \\
\hline 2 & $\begin{array}{l}\text { Aragonite } \\
\quad S\end{array}$ & $\mathrm{CaCO}_{3}=\mathrm{Ca}^{2+}+\mathrm{CO}_{3}^{2-}$ & -8.30 & Boudreau, 1997 \\
\hline 3 & $\begin{array}{l}\text { Sulfur } \\
\mathrm{Fe}\end{array}$ & $\mathrm{S}+\mathrm{H}^{+}+2 \mathrm{e}^{-}=\mathrm{HS}^{-}$ & -2.2 & Jacob and Emerson, 1982 (Huerta Diaz et al., 1998) \\
\hline 4 & Siderite & $\mathrm{FeCO}_{3}=\mathrm{Fe}^{2+}+\mathrm{CO}_{3}^{2-}$ & -10.8 & Martell et al., 2001 (Gallon et al., 2004) \\
\hline 5 & Ferrihydrite & $\mathrm{Fe}(\mathrm{OH})_{3}+3 \mathrm{H}^{+}=\mathrm{Fe}^{3+}+3 \mathrm{H}_{2} \mathrm{O}$ & 3.19 & Parkhurst et Appelo, 1999 \\
\hline 6 & $\mathrm{Fe}(\mathrm{OH})_{2}$ & $\mathrm{Fe}(\mathrm{OH})_{2}=\mathrm{Fe}^{2+}+2 \mathrm{OH}^{-}$ & -14.43 & Martell et al., 2001 (Gallon et al., 2004) \\
\hline 7 & $\mathrm{FeS}(\mathrm{am})$ & $\mathrm{FeS}+\mathrm{H}^{+}=\mathrm{Fe}^{2+}+\mathrm{HS}^{-}$ & -2.95 & Davison, 1991 (Huerta Diaz et al., 1998) \\
\hline 8 & Mackinawite & $\mathrm{FeS}+\mathrm{H}^{+}=\mathrm{Fe}^{2+}+\mathrm{HS}^{-}$ & -3.6 & Davison, 1991 (Huerta Diaz et al., 1998) \\
\hline 9 & Greigite & $\mathrm{Fe}_{3} \mathrm{~S}_{4}+4 \mathrm{H}^{+}=2 \mathrm{Fe}^{3+}+\mathrm{Fe}^{2+}+4 \mathrm{HS}^{-}$ & -34.69 & Davison, 1991 (Huerta Diaz et al., 1998) \\
\hline 10 & Pyrrhotite & $\mathrm{FeS}+\mathrm{H}^{+}=\mathrm{Fe}^{2+}+\mathrm{HS}^{-}$ & -5.1 & Davison, 1991 (Huerta Diaz et al., 1998) \\
\hline 11 & Troilite & $\mathrm{FeS}+\mathrm{H}^{+}=\mathrm{Fe}^{2+}+\mathrm{HS}^{-}$ & -5.25 & Davison, 1991 (Huerta Diaz et al., 1998) \\
\hline 12 & $\begin{array}{l}\text { Pyrite } \\
M n\end{array}$ & $\mathrm{FeS}_{2}+2 \mathrm{H}^{+}+2 \mathrm{e}^{-}=\mathrm{Fe}^{2+}+2 \mathrm{HS}^{-}$ & -11.47 & Davison, 1991 (Huerta Diaz et al., 1998) \\
\hline 13 & Rhodochrosite & $\mathrm{MnCO}_{3}=\mathrm{Mn}^{2+}+\mathrm{CO}_{3}^{2-}$ & -10.58 & NIST, 1993 (Huerta Diaz et al., 1998) \\
\hline 14 & MnS (Green) & $\mathrm{MnS}+\mathrm{H}^{+}=\mathrm{Mn}^{2+}+\mathrm{HS}^{-}$ & 0.4 & Smith and Martell, 1977 (Huerta Diaz et al., 1998) \\
\hline 15 & MnS (pink) & $\mathrm{MnS}+\mathrm{H}^{+}=\mathrm{Mn}^{2+}+\mathrm{HS}^{-}$ & 3.4 & Smith and Martell, 1977 (Huerta Diaz et al., 1998) \\
\hline 16 & Alabandite & $\mathrm{MnS}+\mathrm{H}^{+}=\mathrm{Mn}^{2+}+\mathrm{HS}^{-}$ & 0.17 & Dyrssen and Kremling, 1990 (Balistrieri, 1992) \\
\hline 17 & $\begin{array}{l}\text { Haurite } \\
\text { As }\end{array}$ & $\mathrm{MnS}_{2}+2 \mathrm{H}^{+}+2 \mathrm{e}^{-}=\mathrm{Mn}^{2+}+2 \mathrm{HS}^{-}$ & -3.7 & Dyrssen and Kremling, 1990 (Balistrieri, 1992) \\
\hline 18 & $\mathrm{As}_{2} \mathrm{O}_{5}$ & $\mathrm{As}_{2} \mathrm{O}_{5}+3 \mathrm{H}_{2} \mathrm{O}=2 \mathrm{AsO}_{4}^{3-}+6 \mathrm{H}^{+}$ & -61.95 & Nordstrom and Archer, 2003 (Couture et al., 2010) \\
\hline 19 & $\mathrm{Fe}_{3}\left(\mathrm{AsO}_{4}\right)_{2}$ & $\mathrm{Fe}_{3}\left(\mathrm{AsO}_{4}\right)_{2}=2 \mathrm{AsO}_{4}^{3-}+3 \mathrm{Fe}^{2+}$ & -34.41 & Essington, 1988 (Couture et al., 2010) \\
\hline 20 & $\mathrm{Mn}_{3}\left(\mathrm{AsO}_{4}\right)_{2}: 8 \mathrm{H}_{2} \mathrm{O}$ & $\mathrm{Mn}_{3}\left(\mathrm{AsO}_{4}\right)_{2}: 8 \mathrm{H}_{2} \mathrm{O}=2 \mathrm{AsO}_{4}^{3-}+3 \mathrm{Mn}^{2+}+8 \mathrm{H}_{2} \mathrm{O}$ & -29.02 & Essington, 1988 (Couture et al., 2010) \\
\hline 21 & $\mathrm{Mg}_{3}\left(\mathrm{AsO}_{4}\right)_{2}$ & $\mathrm{Mg}_{3}\left(\mathrm{AsO}_{4}\right)_{2}=2 \mathrm{AsO}_{4}^{3-}+3 \mathrm{Mg}^{2+}$ & -30.02 & Essington, 1988 (Couture et al., 2010) \\
\hline 22 & $\mathrm{Ca}_{3}\left(\mathrm{AsO}_{4}\right)_{2}: 4 \mathrm{H}_{2} \mathrm{O}$ & $\mathrm{Ca}_{3}\left(\mathrm{AsO}_{4}\right)_{2}: 4 \mathrm{H}_{2} \mathrm{O}=2 \mathrm{AsO}_{4}^{3-}+3 \mathrm{Ca}^{2+}+4 \mathrm{H}_{2} \mathrm{O}$ & -21.15 & Bothe and Brown, 1999 (Couture et al., 2010) \\
\hline 23 & $\mathrm{Ca}_{5}(\mathrm{OH})\left(\mathrm{AsO}_{4}\right)_{3}$ & $\mathrm{Ca}_{5}(\mathrm{OH})\left(\mathrm{AsO}_{4}\right)_{3}=3 \mathrm{AsO}_{4}^{3-}+5 \mathrm{Ca}^{2+}+\mathrm{OH}^{-}$ & -38.3 & Bothe and Brown, 1999 (Couture et al., 2010) \\
\hline 24 & $\mathrm{CaHAsO} 4$ & $\mathrm{CaHAsO}_{4}=\mathrm{AsO}_{4}^{3-}+\mathrm{Ca}^{2+}+\mathrm{H}^{+}$ & -16.34 & Bothe and Brown, 1999 (Couture et al., 2010) \\
\hline 25 & Ferrarisite & $\mathrm{Ca}_{5}\left(\mathrm{HAsO}_{4}\right)_{2}\left(\mathrm{AsO}_{4}\right)_{2}=4 \mathrm{AsO}_{4}^{3-}+5 \mathrm{Ca}^{2+}+2 \mathrm{H}^{+}$ & -56.61 & Bothe and Brown, 1999 (Couture et al., 2010) \\
\hline 26 & Guerinite & $\mathrm{Ca}_{5}\left(\mathrm{HAsO}_{4}\right)_{2}\left(\mathrm{AsO}_{4}\right)_{2}=4 \mathrm{AsO}_{4}^{3-}+5 \mathrm{Ca}^{2+}+2 \mathrm{H}^{+}$ & -55.81 & Bothe and Brown, 1999 (Couture et al., 2010) \\
\hline 27 & Arsenolite & $\mathrm{As}_{2} \mathrm{O}_{3}+3 \mathrm{H}_{2} \mathrm{O}=2 \mathrm{AsO}_{3} 3^{-}+6 \mathrm{H}^{+}$ & -77.92 & Nordstrom and Archer, 2003 (Couture et al., 2010) \\
\hline 28 & Claudetite & $\mathrm{As}_{2} \mathrm{O}_{3}+3 \mathrm{H}_{2} \mathrm{O}=2 \mathrm{AsO}_{3}{ }^{3-}+6 \mathrm{H}^{+}$ & -77.95 & Nordstrom and Archer, 2003 (Couture et al., 2010) \\
\hline 29 & Orpiment & $\mathrm{As}_{2} \mathrm{~S}_{3}+6 \mathrm{H}_{2} \mathrm{O}=2 \mathrm{AsO}_{3}{ }^{3-}+9 \mathrm{H}^{+}+3 \mathrm{HS}^{-}$ & -122.8 & Nordstrom and Archer, 2003 (Couture et al., 2010) \\
\hline 30 & Orpiment(am) & $\mathrm{As}_{2} \mathrm{~S}_{3}+6 \mathrm{H}_{2} \mathrm{O}=2 \mathrm{AsO}_{3}{ }^{3-}+9 \mathrm{H}^{+}+3 \mathrm{HS}^{-}$ & -121.4 & Nordstrom and Archer, 2003 (Couture et al., 2010) \\
\hline 31 & $\begin{array}{l}\text { Realgar } \\
\text { Co }\end{array}$ & $\mathrm{AsS}+2.5 \mathrm{H}_{2} \mathrm{O}+0.25 \mathrm{O}_{2}=\mathrm{AsO}_{3} 3^{-}+4 \mathrm{H}^{+}+\mathrm{HS}^{-}$ & -36.9 & Nordstrom and Archer, 2003 (Couture et al., 2010) \\
\hline 32 & CoS(alpha) & $\mathrm{CoS}+\mathrm{H}^{+}=\mathrm{Co}^{2+}+\mathrm{HS}^{-}$ & -7.4 & Smith and Martell, 1977 (Huerta Diaz et al., 1998) \\
\hline 33 & CoS(beta) & $\mathrm{CoS}+\mathrm{H}^{+}=\mathrm{Co}^{2+}+\mathrm{HS}^{-}$ & -11.7 & Smith and Martell, 1977 (Huerta Diaz et al., 1998) \\
\hline 34 & Covellite & $\mathrm{CuS}+\mathrm{H}^{+}=\mathrm{Cu}^{2+}+\mathrm{HS}^{-}$ & -22.27 & Shea and Helz, 1989 (Huerta Diaz et al., 1998) \\
\hline 35 & $\begin{array}{l}\text { Chalcocite } \\
\mathrm{Hg}\end{array}$ & $\mathrm{Cu}_{2} \mathrm{~S}+\mathrm{H}^{+}=2 \mathrm{Cu}++\mathrm{HS}^{-}$ & -17.3 & Smith and Martell, 1977 (Huerta Diaz et al., 1998) \\
\hline 36 & Cinnabar & $\mathrm{HgS}+\mathrm{H}^{+}=\mathrm{Hg}^{2+}+\mathrm{HS}^{-}$ & -39.1 & Martell et al., 2003 (Goulet et al., 2007) \\
\hline 37 & $\begin{array}{l}\text { Metacinnabar } \\
\quad \mathrm{Ni}\end{array}$ & $\mathrm{HgS}+\mathrm{H}^{+}=\mathrm{Hg}^{2+}+\mathrm{HS}^{-}$ & $-36.4^{a}$ & Martell et al. 1998 (Merritt and Amirbahman, 2007) \\
\hline 38 & Millerite & $\mathrm{NiS}+\mathrm{H}^{+}=\mathrm{Ni}^{2+}+\mathrm{HS}^{-}$ & -9.23 & Smith and Martel, 1977 (Huerta Diaz et al., 1998) \\
\hline 39 & NiS(alpha) & $\mathrm{NiS}+\mathrm{H}^{+}=\mathrm{Ni}^{2+}+\mathrm{HS}^{-}$ & -5.50 & Smith and Martel, 1977 (Huerta Diaz et al., 1998) \\
\hline 40 & NiS(beta) & $\mathrm{NiS}+\mathrm{H}^{+}=\mathrm{Ni}^{2+}+\mathrm{HS}^{-}$ & -11.00 & Smith and Martel, 1977 (Huerta Diaz et al., 1998) \\
\hline 41 & NiS(gamma) & $\mathrm{NiS}+\mathrm{H}^{+}=\mathrm{Ni}^{2+}+\mathrm{HS}^{-}$ & -12.70 & Smith and Martel, 1977 (Huerta Diaz et al., 1998) \\
\hline
\end{tabular}

(a) I = $1 \mathrm{M}$ 
Allison, J. D., Brown, D. S., and Novo-Gradac, K. J., 1989. MINTEQA2/PRODEFA2, A Geochemical Assessment Model for Environment Systems: Version 3.0. User's manual. Office of Research and Development, Washington DC.

Amirbahman, A., Reid, A. L., Haines, T. A., Kahl, J. S., and Arnold, C., 2002. Association of Methylmercury with Dissolved Humic Acids. Environ. Sci. Technol. 36, 690-695.

Balistrieri, L. S., Murray, J. W., and Paul, B., 1992. The Cycling of Iron and Manganese in the Water Column of Lake Sammamish, Washington. Limnol. Oceanogr. 37, 510-528.

Boettcher, M., Grund, S., Keiter, S., Kosmehl, T., Reifferscheid, G., Seitz, N., Rocha, P. S., Hollert, H., and Braunbeck, T., 2010. Comparison of in vitro and in situ genotoxicity in the Danube River by means of the comet assay and the micronucleus test. Mutation Research/Genetic Toxicology and Environmental Mutagenesis 700, 11-17.

Bothe, J. V. and Brown, P. W., 1999. The stabilities of calcium arsenates at $23 \pm 1 \infty \mathrm{C}$. J. Hazard. Mater. 69, 197-207.

Couture, R.-M., Gobeil, C., and Tessier, A., 2010. Arsenic, iron and sulfur co-diagenesis in lake sediments. Geochim. Cosmochim. Acta 74, 1238-1255.

Davison, W., 1991. The solubility of iron sulphides in synthetic and natural waters at ambient temperature. Aquatic Sciences - Research Across Boundaries 53, 309-329.

De Robertis, A., Foti, C., Patan $\sqrt{ }($, G., and Sammartano, S., 1998. Hydrolysis of $(\mathrm{CH} 3) \mathrm{Hg}+$ in Different lonic Media:,Äâ Salt Effects and Complex Formation. Journal of Chemical \& Engineering Data 43, 957-960.

Dyrssen, D., 1985. Metal complex formation in sulphidic seawater. Mar. Chem. 15, 285-293.

Dyrssen, D. and Kremling, K., 1990. Increasing hydrogen sulfide concentration and trace metal behavior in the anoxic Baltic waters. Mar. Chem. 30, 193-204.

Essington, M. E., 1988. Estimation of the standard free energy of formation of metal arsenates, selenates, and selenites. Soil Sci. Soc. Am. J. 52, 1574-1579.

Feyte, S., Gobeil, C., Tessier, A., and Cossa, D., 2011. Mercury dynamics in lake sediments. Geochim. Cosmochim. Acta In Press, Accepted Manuscript.

Feyte, S., Tessier, A., Gobeil, C., and Cossa, D., 2010. In situ adsorption of mercury, methylmercury and other elements by iron oxyhydroxides and organic matter in lake sediments. Appl. Geochem. 25, 984-995.

Gallon, C., Tessier, A., Gobeil, C., and Alfaro-De La Torre, M. C., 2004. Modeling diagenesis of lead in sediments of a Canadian Shield lake. Geochim. Cosmochim. Acta 68, 35313545.

Goulet, R. R., Holmes, J., Page, B., Poissant, L., Siciliano, S. D., Lean, D. R. S., Wang, F., Amyot, M., and Tessier, A., 2007. Mercury transformations and fluxes in sediments of a riverine wetland. Geochim. Cosmochim. Acta 71, 3393-3406.

Huerta-Diaz, M. A., Tessier, A., and Carignan, R., 1998. Geochemistry of trace metals associated with reduced sulfur in freshwater sediments. Appl. Geochem. 13, 213-233.

Jacobs, L. and Emerson, S., 1982. Trace metal solubility in an anoxic fjord. Earth and Planetary Science Letters 60, 237-252.

Jay, J. A., Morel, F. o. M. M., and Hemond, H. F., 2000. Mercury Speciation in the Presence of Polysulfides. Environ. Sci. Technol. 34, 2196-2200.

Loux, N., 2007. An assessment of thermodynamic reaction constants for simulating aqueous environmental monomethylmercury speciation. Chem. Spec. Bioavail. 19, 193-206.

Luther, G. W., Rickard, D. T., Theberge, S., and Olroyd, A., 1996. Determination of Metal (Bi)Sulfide Stability Constants of $\mathrm{Mn} 2+, \mathrm{Fe} 2+, \mathrm{Co} 2+, \mathrm{Ni} 2+, \mathrm{Cu} 2+$, and $\mathrm{Zn} 2+$ by Voltammetric Methods. Environ. Sci. Technol. 30, 671-679.

Martell, A. E. and Smith, R. M., 2001. NIST Critically selected stability constants of metal complexes data base. In: 6, V. (Ed.). National Institute of Standards and Technology, Gaithersburg.

Martell, A. E., Smith, R. M., and Motekaitis, R. J., 1998. NIST Critically selected stability constants of metal complexes data base. In: 46, N. S. R. D. (Ed.). National Institute of Standards and Technology, Gaithersburg. 
Martell, A. E., Smith, R. M., and Motekaitis, R. J., 2003. NIST Critically constants for metal complexes data base. In: 46, N. S. R. D. (Ed.). National Institute of Standards and Technology, Gaithersburg.

Merritt, K. A. and Amirbahman, A., 2007. Mercury dynamics in sulfide-rich sediments: Geochemical influence on contaminant mobilization within the Penobscot River estuary, Maine, USA. Geochim. Cosmochim. Acta 71, 929-941.

NIST, 1993. NIST Critically selected stability constants of metal complexes data base. In: 46, N. S. R. D. (Ed.). National Institute of Standards and Technology, Gaithersburg.

Nordstrom, D. K. and Archer, D. G., 2003. Arsenic thermodynamic data and environmental geochemistry. In: Stollenwerk, A. H. W. a. K. G. (Ed.), Arsenic in Ground-water, Boston.

Parkhurst, D. L. and Appelo, C. A. J., 1999. User Guide to PHREEQC (Version 2) : A computer program for speciation, batch-reaction, one-dimensional transport, and inverse geochemical calculations. In: Investigations, U. S. G. S. W.-R. (Ed.).

Powell, K. J., Brown, P. L., Byrne, R. H., Gajda, T., Hefter, G., Sjoberg, S., and Wanner, H., 2005. Chemical speciation of environmentally significant heavy metals with inorganic ligands Part 1: The $\mathrm{Hg}[2][+]-\mathrm{Cl}[-], \mathrm{OH}-, \mathrm{CO}[3] 2-, \mathrm{SO}[4] 2-$, and $\mathrm{PO}[4] 3-$ aqueous systems. Pure and applied chemistry 77, 739-800.

Rabenstein, D. L., Touranqueau, M. C., and Evans, C. A., 1976. Proton magnetic resonance and Raman spectroscopic studies of methylmercury(II) complexes of inorganic anions. Canadian Journal of Chemistry 54, 2517-2525.

Rickard, D. and Morse, J. W., 2005. Acid volatile sulfide (AVS). Mar. Chem. 97, 141-197.

Schoonen, M. A. A. and Barnes, H. L., 1988. An approximation of the second dissociation constant for H2S. Geochim. Cosmochim. Acta 52, 649-654.

Shea, D. and Helz, G. R., 1989. Solubility product constants of covellite and a poorly crystalline copper sulfide precipitate at 298 K. Geochim. Cosmochim. Acta 53, 229236.

Smith, R. M. and Martell, A. E., 1977. Critical Stability Constants. In: Press, P. (Ed.), New York.

Stumm, W. and Morgan, J. J., 1981. Aquatic chemistry, New-York.

Taillefert, M., Lienemann, C.-P., Gaillard, J.-F., and Perret, D., 2000. Speciation, reactivity, and cycling of $\mathrm{Fe}$ and $\mathrm{Pb}$ in a meromictic lake. Geochim. Cosmochim. Acta 64, 169183.

Tipping, E., 2007. Modelling the interactions of $\mathrm{Hg}(\mathrm{II})$ and methylmercury with humic substances using WHAM/Model VI. Appl. Geochem. 22, 1624-1635.

Vlassopoulos, D., Bessinger, B., and O'Day, P., 2010. Aqueous solubility of As2S3 and thermodynamic stability of thioarsenites. In: Birlke, T.-A. (Ed.),13th International Symposium on Water-Rock Interaction. Taylor \& Francis Group, Guanajuato, Mexico.

Whiting, K. S., 1992. The thermodynamics and geochemistry of arsenic with application to subsurface waters at the Sharon Steel superfund site at Midwale, Utah.

Wilkin, R., Wallschlager, D., and Ford, R., 2003. Speciation of arsenic in sulfidic waters. Geochemical Transactions 4, 1. 